
Calumbia ôninersity

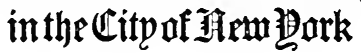

LIBRARY

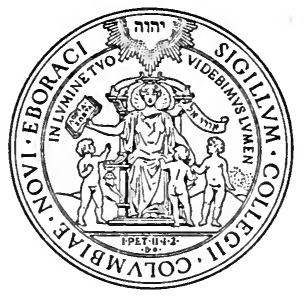





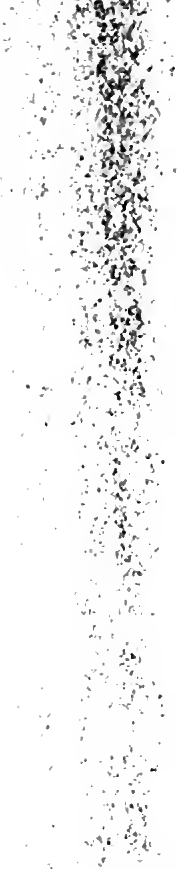

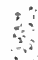


AMERICA'S CASE AGAINST GERMANY 


\section{AMERICA'S CASE}

AGAINST GERMANY

BY

LINDSAY ROGERS, PH.D., LL.B.

ADJUNCT PROFESSOR OF POLITICAL SCIENCE IN

THE UNIVERSITY OF VIRGINIA

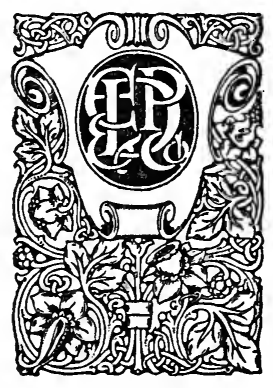

NEW YORK

E. P. DUTTON \& COMPANY 681 FIFTH AVENUE 
COPYRIGHT, 1917,

BI E. P. DUTTON \& CO.

printed in the anited 8tates of America 
TO

MY FATHER AND MOTHER 



\section{PREFACE}

I HAVE attempted in the pages that follow to describe the origin and development of the controversy which was the immediate cause of war between the United States and Germany. The diplomatic exchanges dealing with the submarine issue are not accessible to every one; and in any event they contain so much verbiage and are so arranged that they will not be resorted to in order to secure a knowledge of the issues involved. I have sought to furnish a chronological account of Mr. Wilson's policy-narrative and explanatory, not critical or defensive, for it is too early to pass definite judgment.

There are unmistakable evidences that the justice of our case against Germany has not been clearly understood even by loyal Americans. If one reads the debates in Congress on the war resolution or armed neutrality, for example, he cannot fail to discover an amount of misinformation which is surprising and dis- 
heartening. And so I have thought it worth while to give a treatment of the points of international law involved as brief and untechnical as is consistent with the necessity for explaining the legal grounds of the American position-particularly with regard to the submarine as a new weapon, not subject to established rules, the status of armed merchant ships, the problem of munition exports, and the difference between the English and German "blockades." These are the problems which seem to have caused the greatest confusion of thought, and no attempt has yet been made to treat them together and to furnish the basis upon which war with Germany was inevitable.

In the introductory chapter I refer briefly to the fact that President Wilson has ascribed our participation in the war to the duty of fighting for peace, democracy, and liberty against a state which has committed terrible outrages on these ideals, and that there are grounds, other than the legal one, upon which our case against Germany may be rested. The formulation of a moral indictment is not here attempted; it has already been repeatedly 
drawn up in the literature which seeks to explain the purposes of those nations which are now our Allies. Germany was guilty of a brutish invasion of human rights everywhere, and it was simply one phase of this-the callous assassination, not alone on the high seas, of noncombatant citizens of both sexes and all ages-which so aroused the indignation of America that war was inevitable. The mere unlawfulness of the submarine warfare was not decisive; that might have been overlooked. But it is nevertheless true that the purely legal issue is of fundamental importance, because if American citizens had not had a legal right to travel unmolested, even when on armed merchantmen; if American vessels, no matter with what cargoes, had not had a legal immunity from destruction until the lives of their passengers and crew were safeguarded, the United States would have been unable to protest against the war zone decree, to announce that Germany would be held to a "strict accountability," and to consider the sinking of the Lusitania "deliberately unfriendly." But for the fact that the United States could rest its 
case upon the unquestioned principles of international law, it is certain that the exercise of personal privileges, unprotected by international agreement, would not have been supported at the cost of war.

To be sure, Mr. Wilson's protests were in part calculated to stay an international ruthlessness which demanded our condemnation and threatened, if it did not already affect, our interests. But the repeated disregard by Germany of legal rights was responsible for the moral indignation which made war inevitable, and it is of fundamental importance, I take it, that the correctness of America's legal position be understood, because, but for it, we would still be at peace. It is only one, but it is the primary and indispensable part of America's case against Germany, and to contribute to its understanding-which should be had by every intelligent citizen-this book has been written. 


\section{BIBLIOGRAPHICAL NOTE}

A vast amount of material has appeared in print dealing with international law and the war generally, and with the submarine question particularly. Much of this is of a very ephemeral character, and it would be futile to attempt any exhaustive bibliography. Attention may, however, be properly drawn to some of the more accessible and important authorities.

The diplomatic documents on the submarine controversy have been published in several forms. The Department of State has issued three White Papers (the last appearing on August 12, 1916); the correspondence then available appears, very competently edited, in Supplements (July, 1915, and October, 1916) to the American Journal of International Law; some of the documents are available in the convenient form of the pamphlets of the World Peace Foundation and the American Association for International Conciliation; many of 


\section{xii BIBLIOGRAPHICAL NOTE}

them were published in the Congressional Record from time to time, and Congressman S. D. Fess has attempted to collect them all under the title, "The Problems of Neutrality When the World Is at War" (64th Congress, $2 \mathrm{~d}$ Session, House Document, 2111). Most of the more important notes appear without abridgment in The New York Times Current History, which is valuable also for an account of all the submarine outrages, some of which did not figure in the diplomatic exchanges.

The most elaborate secondary work is Dr. Coleman Phillipson's International Law and the Great War (London, 1915, and New York, 1916), but this was completed immediately after the sinking of the Lusitania. More valuable is the material which has appeared in the American Journal of International Law. Under the general heading "International Law and the European War," Professor James W. Garner has discussed "The Use of Submarine Mines" (Vol. IX, p. 86); "Contraband, Right of Search, and Continuous Voyage"'(Ibid., p. 372); "War Zones and Submarine Warfare" (Ibid., p. 594); "Destruction of Neutral Merchant Ves- 
sels" (Vol. X, p. 12) ; "The Sale and Exportation of Arms and Munitions of War to Belligerents" (Ibid., p. 749). Elaborate editorials by the distinguished editor of the Journal, Dr. James Brown Scott, cover practically all of the legal questions to which the war has given rise.

Worthy of mention also are the following: Edwin J. Clapp, Economic Aspects of the War (New Haven, 1915), which attacks England's restrictions on trade; Sir Francis Piggott, The Neutral Merchant and Contraband of War and Blockade (London, 1915), which is by far the best defense of the Orders in Council and deserves an American edition; Sir Frederick Smith, The Destruction of Merchant Ships under International Law (London, 1917); A. Pearce Higgins, Defensively Armed Merchant Ships and Submarine Warfare (London, 1917), which is an amplified edition of his American Journal of International Law article (Vol. VIII, p. 705; also published as Senate Document No. 332, 64th Congress, 1st Session); Raleigh C. Minor, "The Rule of Law Which Should Govern the Conduct of Submarines with Reference to Enemy and Neutral Merchant 
xiv BIBLIOGRAPHICAL NOTE

Vessels and the Conduct of Such Vessels Toward Submarines" (Proceedings of the American Society of International Law, 1916, Vol. X, p. 51) -an extremely clear statement of the rules, and William Cullen Dennis, "Rights of Citizens of Neutral Countries to Sell and Export Arms and Munitions of War to Belligerents" (Annals of the American Academy of Political and Social Science, Vol. LX, p. 168).

Special attention should be directed, finally, to two articles, each of which gives, I think, the best discussion thus far of its particular subject. An anonymous writer, evidently an American, contributes to The Round Table (June, 1916, No. 23) a remarkably able article on "The German-American Submarine Controversy,", which discusses the most important points up to the sinking of the Sussex; and Professor Monroe Smith gives in the Political Science Quarterly (December, 1916) a sometimes cursory but always incisive and fair consideration of "American Diplomacy in the European War." 


\section{TABLE OF CONTENTS}

Preface . . . . . . . . . . . . v vii

Bibliographical Note . . . . . . . . xi CHAPTER

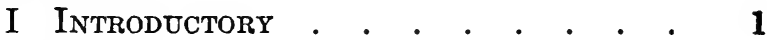

II The War Zone Decrees and Germany's Submarine Blockade . . . . . 11

III Some Points of International Law . 40

IV The "Lusitania" and Other Outrages 60

V The German Pledges . . . . . 97

VI The Trade in Munitions of War . . 109

VII Submarine Warfare in the MediterRANEAN • • • • • • • . . 138

VIII Armed Merchantmen . . . . . 153

IX The "Sussex" and the Pledges. . . 170

X The Parting of the Ways . . . . 189

XI Overt Acts, Armed Neutrality, aNd WAR . . . . . . . . . . 207

XII The Right of Retaliation . . . . 224

Appendix · (I) President Wilson's Address to

Congress Asking for a Declaration of War.

(iI) Official List of German Outrages on American Ships and Lives . . . . . . 237

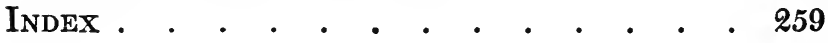



AMERICA'S CASE AGAINST GERMANY 


\section{AMERICA'S CASE AGAINST GERMANY}

\section{CHAPTER I}

INTRODUCTORY

No war in which the United States has ever engaged has had greater justification than the one recognized on April 6, 1917. The language of the congressional resolution, which asserted that the Imperial German Government had "committed repeated acts of war" and formally declared a status which had been "thrust upon" the United States of America, was strictly accurate, because for more than two years President Wilson attempted in vain to persuade Germany to abandon the wanton sinking of merchant vessels in disregard of the undisputed rules of international law and elementary dictates of humanity. In the refusal of the Imperial Government to cease the murder 


\section{AMERICA'S CASE AGAINST GERMANY}

of American citizens and the destruction of American property is to be found the immediate cause of the entrance of the United States into the European conflict; and while our abandonment of the intolerable rôle of neutral enables us formally to declare what many of us have long felt-that the Allies have been fighting for our ideals; that the submarine warfare is simply symptomatic of an international ruthlessness which cannot be allowed to triumph; that, in President Wilson's phrase, it is a warfare against all mankind, against all nations-nevertheless the reason why the United States finally decided to substitute force for argument was the continued assertion by Germany of the right to use the submarine against commerce. This, he maintained, could not be done except in violation of principles of international law so humane and so fundamental that their abandonment by a proud, self-respecting nation was unthinkable.

The immediate cause of a war may be lost sight of in larger issues and this is abundantly true in the present instance. We are prone to justify our entrance on the basis of American 
approval of the purposes of the Entente Allies and disapproval of the purposes of the Central Powers. In the opinion of a great many Americans an international conscience would long ago have justified us in casting in our lot on the side of England and France. Before the submarine campaign was inaugurated it had become trite to say that American public opinion was wholeheartedly sympathetic with the Allies; that America was very generally convinced that if Germany did not will the war, she did not exert herself-at least until too late-to avert such a terrible catastrophe; that the theory of the State as power-preached by Treitschke and popularized by Bernhardi-is exactly contrary to the political beliefs of democratic, liberty-loving America; that in a struggle between Prussian military autocracy and democratic ideals our support could not but be given to the latter, and that America abhors this Prussian ideal as evidenced in actual fact: the invasion of Belgium, the atrocities, the violations of international law-all deeds in fulfillment of the injunction of the German War Book that an effort should be made to destroy the complete mate- 


\section{AMERICA'S CASE AGAINST GERMANY}

rial and moral resources of the enemy. "War is an act of violence which in its application knows no bounds." The submarine campaign, with its disregard of the distinction between combatants and noncombatants, with its violation of sacred principles of international law and humanity, has simply been another evidence of this theory. The Allies are fighting our battle; they have been sacrificing for everything we believe in to combat the things that we do not believe in. Only an Allied victory can insure a stable peace and America should not stand indifferently, but should make sacrifices in its turn to fulfill this noble purpose.

Again, the belief is now widely held that the refusal of the United States to continue on friendly relations with Germany may be justified on the ground of policy, on a consideration of our own material interests as the greatest nation of the Western World. A successful outcome of the submarine campaign would mean the destruction of the British Navy, first of all, and secondly, the dismemberment of the British Empire. Without England's sea power to support it, the Monroe Doctrine would be- 
come a mere brutum fulmen; it would be safer to cancel it as obsolete rather than attempt to enforce it. The security of the colonial possessions of the United States would be endangered and this country would face a most calamitous trade war. The points need not be argued. A moment's reflection is all that is necessary to establish them; and incontrovertible evidence has been furnished by the Zimmermann proposal to Japan and Mexico to join with Germany in an alliance against the United States.

But these considerations were not the ones which forced the United States into war with Germany. The real reason was assigned by President Wilson when he announced to Congress that diplomatic relations had been broken : Germany had wantonly violated international law; she had disregarded the absolute immunity which all neutral citizens have when on the high seas in private, unresisting vessels; she had made pledges only to break them, and her final announcement was so flagrant in its disregard of international right, so insulting in its demands upon the United States, that self-respect alone was sufficient to compel the action then 
taken, and when, during the ensuing two months, Germany continued her submarine campaign, if anything more ruthlessly, war, as the ultima ratio, was forced upon the United States; and a nation which up until then had at times appeared too ready to compromise, too eager to avoid an absolute impasse in the controversy, prepared to prosecute its right by force.

Mr. Wilson's address to Congress asking for a declaration of war recognized the grounds other than those upon which his diplomatic notes had been based. "We are now," he said, "about to accept the gage of battle with this natural foe to liberty and shall, if necessary, spend the whole force of the nation to check and nullify its pretensions and power. We are glad, now that we see the facts with no veil of false pretense about them, to fight thus for the ultimate peace of the world and for the liberation of its peoples, the German peoples included; for the rights of nations, great and small, and the privilege of men everywhere to choose their way of life and obedience." And the war was demanded, also, for the pres- 
ervation of our own safety, since the German Government "entertains no real friendship for us, and means to act against our peace and security at its convenience. That it means to stir up enemies against us at our very doors the intercepted note to the German Minister at Mexico City is eloquent evidence."

Yet it remains true that; if it had not been for the submarine warfare, we would probably have remained at peace with Germany; and in regarding such a weapon as evidence that the Imperial Government refuses to subscribe to the humane practices of civilized nations and persists in denying one of international law's most fundamental principles-that the effects of war should be limited to the armed forces of the enemy; in believing that we are fighting for liberty, democracy, and governmental decency, we should not forget the patience which has marked our protests to Germany, nor should we be unmindful of the fact that the contentions of the United States have been morally and legally correct in every particular.

Great wars always cause the sacrifice of neutral rights. This is nothing to be wondered at, 


\section{AMERICA'S CASE AGAINST GERMANY}

since those rules of international law, the violation or extension of which works such hardships on the nations which remain at peace, while sometimes marking-as with respect to contraband-a compromise between belligerent and neutral interest, have resulted largely from prize court decisions and from conferences of military and naval experts, both sources being greatly prejudiced in favor of the enlargement of belligerent right. In the present conflict, the United States has suffered very extensively and very vitally, not only on account of the magnitude of the struggle, but on account of the character of the violations of international law. On the part of one group of belligerents, these have involved only property rights and the question of damages is arbitrable. The other group of belligerents has taken over two hundred American lives-and the lives of at least two thousand other noncombatantsand has persisted in a policy so wanton that it could not be further endured.

As President Wilson said in April, 1916, when he threatened to break off diplomatic relations on account of the sinking of the Sussex, the Gov- 
ernment of the United States has been patient to the point of tolerance; it has accepted successive explanations and assurances in good faith, and it has made allowance for unprecedented conditions, but it could not continue to suffer violations of "the principles of humanity, the long established and incontrovertible rights of neutrals, and the sacred immunities of noncombatants." With only protests the United States time and time again answered acts which were fully justifiable grounds for hostilities, and which even seemed to invite a declaration of war. But the pronouncement of January 31, 1917-that, with an avowed disregard for neutral as well as enemy noncombatants, women and children as well as men, Germany would sink all merchant vessels-made further friendly relations impossible; and the wholly unrestricted destruction-even of hospital ships -made war inevitable. ${ }^{1}$

${ }^{1}$ The following dispatch, for example, appeared in the papers on April 29th:

"Copenhagen, April 28.-Announcement was made before the Reichstag main committee in Berlin yesterday that Germany will adopt the sharpest reprisals if German prisoners are embarked on hospital ships of the Allies and exposed to the danger of torpedoes." 
10 AMERICA'S CASE AGAINST GERMANY

And now that hostilities have begun, it is worth while to attempt a history of our patient protests, for they tell the story of repeated indignities and contain an adequate statement of the undisputed legal principles upon which our position has rested. They justify to the utmost measure our going to war with Germany, while meeting England's naval activities with only argumentative protests. It is to the story of our negotiations with Germany and comment on the points of international law in issue, that this book will be devoted. 


\section{CHAPTER II}

THE WAR ZONE DECREES AND GERMANY'S SUBMARINE "BLOCKADE"

THe right to use submarines against merchant vessels-and it is the assertion by Germany of that right to which the United States has objected-is bound up with the question of war zones, strategic areas from which private vessels are warned. The latter problem is a new one in international law and as yet largely unregulated. One of the first applications of the principle that a certain portion of the high seas may be designated by belligerents; that therein they may exercise their rights of capture and sinking to the fullest degree, and that neutral vessels are more likely to come to grief on account of hostile operations, was in a Japanese ordinance issued two weeks before the outbreak of the war with Russia. Instead of a war zone the restricted vicinity was called a "defense sea 


\section{AMERICA'S CASE AGAINST GERMANY}

area," and among other regulations merchant vessels were forbidden ingress and egress at night. This involved no important questions of international law, ${ }^{1}$ but in spite of the indefiniteness of the rules concerning war zones, several considerations may be ventured.

In the first place, while neutral vessels may be warned of impending danger if they enter the specified areas, it is indisputabie that merely by conveying such a warning the belligerent acquires no additional rights within the zone other than those he has outside. The waters which are sought to be restricted remain a portion of the high seas and the neutral has a right to navigate them. Furthermore, while the Second Hague Peace Conference refused to adopt the proposal of the British delegation that the laying of mines in the open seas be absolutely prohibited, it is doubtful whether a belligerent has any right to sow mines in such places that neutral ships will be destroyed while engaged in peaceful navigation. ${ }^{2}$

${ }^{1}$ A good discussion of the problem is to be found in International Law Situations, 1912, pp. 114-139.

2 Two recent English writers of high authority attach "no special importance to the declaration issued by the British 
A war zone in the present conflict was first declared by Great Britain on October 13, 1914, when an Admiralty announcement stated that His Majesty's Government had authorized a mine laying policy in certain areas, and that it would be dangerous for ships to cross these limits. This was simply a notice to mariners but three weeks later (November 3rd), the Admiralty announced that since the Germans had scattered mines indiscriminately on the main trade route from America to Liverpool via the North of Ireland with the subsequent destruction of innocent ships (and the White Star Liner Olympic had had a lucky escape), it would be "necessary to adopt exceptional measures appropriate to the novel conditions under which this war is being waged." Notice was therefore given

"that the whole of the North Sea must be considered a military area. Within this area merchant shipping Admiralty affecting to make the North Sea 'a military area.' All that such a declaration ean effect is to put neutrals on guard: to inform them that their presence in such waters will be regarded as suspicious, and that, when navigating there, they will be more than ordinarily liable to eharges of contraband trading or of unneutral service. Probably no more is meant.' 'T. Baty and J. H. Morgan, War: Its Conduct and Legal Results, pp. 224-225. 


\section{AMERICA'S CASE AGAINST GERMANY}

of all kinds, traders of all countries, fishing craft, and all other vessels will be exposed to the gravest dangers from mines which it has been necessary to lay, and from warships searching vigilantly by night and day for suspicious craft. All merchant and fishing vessels of every description are hereby warned of the dangers they encounter by entering this area except in strict accordance with Admiralty directions. Every effort will be made to convey this warning to neutral countries and to vessels on the sea, but from the 5th of November onward the Admiralty announce that all ships passing a line drawn from the northern point of the Hebrides through the Faroe Islands to Iceland do so at their own peril."

Ships wishing to trade with Norway, Denmark, Holland, etc., were advised to come by the English Channel where they would be given sailing directions for a safe passage. Adherence to the routes advised would permit commerce to reach its destination, "so far as Great Britain is concerned, but any straying even for a few miles from the course thus indicated, may be followed by fatal consequences." In a statement made to the House of Commons on November 17th, Mr. Asquith said that for the first two months of the war Great Britain had ab- 
stained absolutely from the use of mines outside of British territorial waters; but Germany, the Admiralty declared, using a merchant vessel flying a neutral flag had sowed mines indiscriminately, and thus "wantonly and recklessly endangered the lives of all who travel on the sea regardless of whether they are friend or foe, civilian or military in character.' A counter measure was therefore necessary.

Against this action, the United States entered no protest. But, while the wisdom of acquiescence seems doubtful, and while even by the British measure the lives of noncombatants were endangered, England's command of the seas enabled her to afford pilots to American ships and to reduce to a minimum the possibility of disaster so far as the mines laid by her were concerned. And England, it should be remembered, expressed the desire to safeguard neutral interests in every possible manner, and notified neutrals of the dangerous area in accordance with the Hague Convention. The German mine laying was surreptitious and was denied, but that it was prior to the British measure seemed established. The German "war 


\section{AMERICA'S CASE AGAINST GERMANY}

zone decree," however, which marked the beginning of the controversy with the United States, was of a much more sinister character.

Late in 1914 Admiral Von Tirpitz said that the submarine would be used to sink merchant vessels in British waters, but the rules of international law enumerating the exceptional cases in which prizes might be destroyed - the safety of passengers and crew always being an indispensable sine qua non-were so definite, and the considerations of humanity so potent, that such a procedure was almost unthinkable, and so not much attention was paid to the German admiral's announcement. On February 4, 1915, however, there was issued the proclamation decreeing the destruction of merchant vessels by submarines. It read as follows:

" 1 . The waters surrounding Great Britain and Ireland including the whole English Channel are hereby declared to be war zone. On and after the 18th of February, 1915, every enemy merchant ship found in the said war zone will be destroyed without its being always possible to avert the danger threatening the crews and passengers on that account.

"2. Even neutral ships are exposed to danger in the war zone as in view of the misuse of neutral 
flags ordered on January 31st by the British Government and of the accidents of naval war, it cannot always be avoided to strike even neutral ships in attacks that are directed at enemy ships.

"3. Northward navigation around the Shetland Islands, in the eastern waters of the North Sea and in a strip of not less than 30 miles width along the Netherlands coast is in no danger."

A memorial of the Imperial German Government accompanying this proclamation frankly justified it as a retaliatory measure for Great Britain's interferences with German trade. Long afterward (March, 1916) the ground of defense was shifted and it was claimed that the use of the submarine against private vessels could not be illegal because, the weapon being a new one, there were no rules on the subject. But this obviously fallacious argument-to be considered more in detail later -was not advanced by the original German memorial. This alleged many violations of international law on the part of Great Britain: the repudiation of the Declaration of London; the extension of contraband lists; the abandonment of the distinction between absolute and 


\section{AMERICA'S CASE AGAINST GERMANY}

conditional contraband; the seizure of noncontraband German goods on neutral vessels, and the declaration that the North Sea should be an area of war,

"thereby rendering difficult and extremely dangerous, if not impossible, all navigation on the high seas between Scotland and Norway, so that they have in a way established a blockade of neutral coasts and ports, which is contrary to the elementary principles of generally accepted international law. Clearly all these measures are part of a plan to strike not only the German military operations, but also the economic system of Germany, and in the end to deliver the whole German people to reduction by famine, by intercepting legitimate neutral commerce by methods contrary to international law."

Complaint was made that the powers not at war had acquiesced in the measures taken by Great Britain, and looked with indulgence on these violations of neutrality; that neutrals were satisfied with theoretical protests.

"The time has come," the memorandum continued, "for Germany also to invoke such vital interests. It therefore finds itself under the necessity, to its regret, of taking military measures against England 
in retaliation of the practice followed by England. Just as England declared the whole North Sea between Scotland and Norway to be comprised within the seat of war, so does Germany now declare the waters surrounding Great Britain and Ireland, including the whole English Channel, to be comprised within the seat of war, and will prevent by all the military means at its disposal all navigation by the enemy in those waters. To this end it will endeavor to destroy, after February 18 next, any merchant vessels of the enemy which present themselves at the seat of war above indicated, although it may not always be possible to avert the dangers which may menace persons and merchandise. Neutral powers are accordingly forewarned not to continue to intrust their crews, passengers, or merchandise to such vessels. Their attention is furthermore called to the fact that it is of urgency to recommend to their own vessels to steer clear of these waters. It is true that the German Navy has received instructions to abstain from all violence against neutral vessels recognizable as such; but in view of the hazards of war, and of the misuse of the neutral flag ordered by the British Government, it will not always be possible to prevent a neutral vessel from becoming the victim of an attack intended to be directed against a vessel of the enemy....

"The German Government announces this measure at a time permitting enemy and neutral ships to make 


\section{AMERICA'S CASE AGAINST GERMANY}

the necessary arrangements to reach the ports situated at the seat of war. They hope that the neutral powers will accord consideration to the vital interests of Germany equally with those of England, and will on their part assist in keeping their subjects and their goods far from the seat of war; the more so since they likewise have a great interest in seeing the termination at an early date of the war now ravaging."

Against this announcement the United States, with other neutrals, protested very vigorously and there was sent to Germany the celebrated "strict accountability" note of February 10, 1915. The Government of the United States called attention to the serious possibilities of the course contemplated, and requested "the Imperial German Government to consider, before action is taken, the critical situation in respect of the relations between this country and Germany which might arise were the German naval forces, in carrying out the policy foreshadowed in the Admiralty's proclamation, to destroy any merchant vessel of the United States or cause the death of American citizens."

The sole right of a belligerent dealing with neutral vessels on the high seas, Germany was 
reminded, is limited to visit and search, unless a blockade is proclaimed and made effective-a measure which the German proclamation did not propose-and

"To declare or exercise a right to attack and destroy any vessel entering a prescribed area of the high seas without first certainly determining its belligerent nationality and the contraband character of its cargo would be an act so unprecedented in naval warfare that this Government is reluctant to believe that the Imperial Government of Germany in this case contemplates it as possible. The suspicion that enemy ships are using neutral flags improperly can create no just presumption that all ships traversing a prescribed area are subject to the same suspicion. It is to determine exactly such questions that this Government understands the right of visit and search to have been recognized."

Germany was told, further, that the Government of the United States could not be accused of acquiescence in the measures taken by Great Britain to restrain neutral trade; that, on the contrary, it had insisted upon the observance of the recognized principles of international law and was free to hold the Allied Governments responsible for damage to American shipping; 


\section{AMERICA'S CASE AGAINST GERMANY}

and that it could take, with a clear conscience, the position indicated in this reply to the German proclamation. Therefore a solemn, and apparently definite and final warning was conveyed to Germany in strong words which have been much quoted:

"If the commanders of German vessels of war should act upon the presumption that the flag of the United States was not being used in good faith and should destroy on the high seas an American vessel or the lives of American citizens, it would be difficult for the Government of the United States to view the act in any other light than as an indefensible violation of neutral rights which it would be very hard indeed to reconcile with the friendly relations now so happily subsisting between the two Governments.

"If such a deplorable situation should arise, the Imperial German Government can readily appreciate that the Government of the United States would be constrained to hold the Imperial German Government to a strict accountability for such acts of their naval authorities and to take any steps it might be necessary to take to safeguard American lives and property and to secure to American citizens the full enjoyment of their acknowledged rights on the high seas. 
"The Government of the United States, in view of these considerations, which it urges with the greatest respect and with the sincere purpose of making sure that no misunderstanding may arise and no circumstance occur that might even cloud the intercourse of the two Governments, expresses the confident hope and expectation that the Imperial German Government can and will give assurance that American citizens and their vessels will not be molested by the naval forces of Germany otherwise than by visit and search, though their vessels may be traversing the sea area delimited in the proclamation of the German Admiralty."

This protest of the United States, it will be noticed, was based almost entirely on the principle that American vessels could not, by any such order, be kept out of the war zone and little attention was paid to the rights of American citizens on belligerent vessels either as passengers or as members of the crew. As for the rights of American vessels, it may be pointed out here that, under the accepted principles of international law, vessels belonging to a neutral may not be captured and confiscated by a belligerent except when carrying a cargo more than half of which is contraband or when 


\section{AMERICA'S CASE AGAINST GERMANY}

attempting to violate a blockade. Now, the fundamental principle of a blockade is that in order to be binding, that is, to make legal the confiscation of vessels attempting to pass, it must be effective. Since, during the first nine weeks after the German decree, according to the London Times, British ports had 11,635 arrivals and sailings, and of these only thirty-five steamers were sunk by submarines, it is obvious that the German measure was not binding and nothing more than a "paper blockade." Hence, German submarines and cruisers had the right to capture a neutral vessel only on account of the contraband character of the cargo, and if the right of capture was thus restricted, the right of destruction was still further limited. ${ }^{3}$

To this communication Germany replied on February 16th in a long memorandum which reviewed at even greater length than the original memorial the basis of such a measure as that contemplated. The note was very polite and attempted to counteract the unfavorable impressions among neutrals which had been ${ }^{2}$ See the discussion of this right in the following chapter. 
caused by the first memorandum. Germany, it was said,

"is to all intents and purposes cut off from oversea supplies with the toleration, tacit or protesting, of the neutrals regardless of whether it is a question of goods which are absolute contraband or only conditional contraband or not contraband at all, following the law generally recognized before the outbreak of the war. On the other hand England with the indulgence of neutral Governments is not only being provided with such goods as are not contraband or merely conditional contraband, namely, foodstuffs, raw material, et cetera, although these are treated by England when Germany is in question as absolute contraband, but also with goods which have been regularly and unquestionably acknowledged to be absolute contraband. The German Government believe that they are obliged to point out very particularly and with the greatest emphasis, that a trade in arms exists between American manufacturers and Germany's enemies which is estimated at many hundred million marks.

"The German Government have given due recognition to the fact that as a matter of form the exercise of rights and the toleration of wrong on the part of neutrals is limited by their pleasure alone and involves no formal breach of neutrality. The German Government have not in consequence made any charge 


\section{AMERICA'S CASE AGAINST GERMANY}

of formal breach of neutrality. The German Government cannot, however, do otherwise, especially in the interest of absolute clearness in the relations between the two countries, than to emphasize that they, in common with the public opinion in Germany, feel themselves placed at a great disadvantage through the fact that the neutral powers have hitherto achieved no success or only an unmeaning success in their assertion of the right to trade with Germany, acknowledged to be legitimate by international law, whereas they make unlimited use of their right to tolerate trade in contraband with England and our other enemies. Conceded that it is the formal right of neutrals not to protect their legitimate trade with Germany and even to allow themselves knowingly and willingly to be induced by England to restrict such trade, it is on the other hand not less their good right, although unfortunately not exercised, to stop trade in contraband, especially the trade in arms, with Germany's enemies."

After six months of "patience and watchful waiting,' Germany had been compelled to meet this "murderous method of conducting maritime war with drastic counter measures," and the note declared that

"If England invokes the powers of famine as an ally in its struggle against Germany with the inten- 
tion of leaving a civilized people the alternative of perishing in misery or submitting to the yoke of England's political and commercial will, the German Government are to-day determined to take up the gauntlet and to appeal to the same grim ally. They rely on the neutrals who have hitherto tacitly or under protest submitted to the consequences, detrimental to themselves, of England's war of famine to display not less tolerance toward Germany, even if the German measures constitute new forms of maritime war, as has hitherto been the case with the English measures." 4

${ }^{4}$ Complaint was made particularly that the American ship Wilhelmina, en route to Hamburg, had been seized although the "cargo was destined solely for the civil population of Germany and was to be used only for this purpose according to an express declaration of the German Government.', But in January, 1915, the Federal Council of Germany decreed that after February 1st, grain and flour imported should be taken over by the Government. Foodstuffs are conditional contraband and are liable to seizure if they are destined for the armed forces. England therefore claimed that in view of this decree all foodstuffs shipped into Germany after February 1st would be liable to seizure, since it would be impossible to distinguish between what was intended for the civilian population and what for the Government. England's action was not considered legal by the United States which protested. It should be said, however, that there was some justification as a measure of reprisal for a decision to consider food absolute contraband since the Dutch vessel Maria, with a cargo of grain for Ireland, was destroyed by the German cruiser Karlsruhe, in September, 1914, without ascertaining the destination of the grain.

"The German Government can not have it both ways," said 
Nevertheless, in spite of the claim that the starvation policy was illegal and the assumption that, as "a matter of course" neutrals would not oppose the forcible suppression of the trade in contraband, the note went on to admit the justness of the American contention and said:

"It is very far indeed from the intention of the German Government, acting in obedience to these compelling circumstances, ever to destroy neutral lives and neutral property, but on the other hand they cannot be blind to the fact that dangers arise through the action to be carried out against England which menace without discrimination all trade within the area of maritime war. This applies as a matter of course to war mines which place any ship approaching a mined area in danger, even if the limits of international law are adhered to most strictly."

a memorandum of the British Foreign Office. "If they consider themselves justified in destroying by bombardment the lives and property of peaceful civil inhabitants of English open towns and watering places, and in seizing and sinking ships and cargoes of conditional contraband on the way thither, on the ground that they are consigned to a fortified place or base, 'a fortiori' His Majesty's Government must be at liberty to treat Hamburg, which is in part protected by the fortifications at the mouth of the Elbe, as a fortified town, and as a base of operations and supply. ....' Germany, it may be added, destroyed the American ship William P. Frye, which was bound for Falmouth, Queenstown, or Plymouth with a cargo of wheat. But this incident is adverted to later. 
Hope was expressed that neutral shipping would shun the dangers of mines by staying away from the area of maritime war-this being the safest method of avoiding "unfortunate accidents." It was asserted furthermore that the original announcement covered only enemy merchant vessels, not all merchant vessels:

"This limitation which the German Government have imposed upon themselves impairs the military purpose, especially since the presumption will prevail, even in the case of neutral ships, that they have contraband on board, in view of the interpretation of the idea of contraband in which the English Government have indulged as regards Germany and which the German Government will accordingly apply against England.

"Naturally the Imperial Government are not willing to waive the right to establish the presence of contraband in the cargoes of neutral ships and, in cases requiring it, to take any action necessary on the grounds established. Finally the German Government are prepared to accord, in conjunction with the American Government, the most earnest consideration to any measure that might be calculated to insure the safety of legitimate shipping of neutrals within the seat of war." 
Efforts in this direction, however, were hampered by the "misuse" of the neutral flag on English vessels and by the carriage of absolute contraband in neutral bottoms. As for the latter, the note expressed the hope "that the American Government upon reconsideration will see their way clear to a measure of intervention in accordance with the spirit of true neutrality." As for the first, German efforts would be without avail if neutral vessels were not marked in a manner admitting of no doubt; and the protest to England against the use of the American flag was welcomed. ${ }^{5}$ The suggestion was made that the United States provide a convoy for American vessels carrying no contraband; but the note again promised future gratitude on the part of the German Government if-and this of course would be just as satisfactory as the right to take unrestricted measures against neutral shipping-" the American Government would urgently advise their

- In the expectation that England would not use the American flag, "the commanders of the German submarines have been instructed, as was already stated in the note of fourth instant, to abstain from violence to American merchant vessels 'when they are recognizable as such.', 
merchant vessels to avoid the English seat of maritime war, at any rate until the flag question is settled." 6

Germany had thrown out the hint, in this note, that if the Allies could be persuaded to adhere to the Declaration of London, she might withdraw her submarine and war zone order and it is likely that at any time during the war she would have been willing to make this concession if permitted to import foodstuffs, and if the trade in munitions between the United States and the Allies had ceased. Accordingly Secretary of State Bryan sent, on February 20th, identic communications to Great Britain and Germany asking for mutual concessions so that an international modus operandi might be achieved which would not be fraught with such

- This note complained that "the British Government have armed English merchant vessels and instructed them to resist by force the German submarines. In these circumstances it is very difficult for the German submarines to recognize neutral merchant vessels as such, for even a search will not be possible in the majority of cases, since the attacks to be anticipated in the case of a disguised English ship would expose the commanders conducting a search and the boat itself to the danger of destruction," but no particular stress was laid upon this point. The questions of international law will receive consideration later. 


\section{AMERICA'S CASE AGAINST GERMANY}

a menace to neutrals. The United States would not surrender any rights, but modified practices on the part of the belligerents were asked to safeguard these rights.

Great Britain and Germany were asked to agree (1) not to sow any floating mines except within common range of harbors for defensive purposes; (2) not to use submarines to attack merchant vessels, belligerent or neutral, except to enforce the right of visit and search; and (3) not to use neutral flags as a ruse de guerre. Germany on her part was asked to permit all importations of food to be consigned to agencies designated by the United States, and to give assurances that the food would not be requisitioned or diverted for the armed forces, but would be distributed solely to retailers whose licenses would permit them to furnish to noncombatants only. The concession asked from Great Britain was that food would not be placed upon the list of absolute contraband, and that shipments to these designated agencies would not be interfered with. It was made clear that the United States, in this, the first of its proposals to secure mutual concessions from the 
belligerents to safeguard American interests and change conditions which caused infringement of American rights, was not admitting or denying "any belligerent or neutral right established by the principles of international law.'"

The reply of Germany to the American proposals was made on February 28th. It agreed that unanchored mines should not be used, but declined to forego the employment of mines for offensive purposes. As for the use of submarines against merchant vessels, the American suggestion was accepted but the acquiescence was immediately negatived, as will be found to be the case in a great many of the German communications, by a truly remarkable statement: "It would appear to be a matter of course that such mercantile also abstain from arming themselves and from all resistance by force, since such procedure contrary to international law would render impossible any action of the submarines in accordance with international law."

These words which I have italicized would seem to admit absolutely the American contention that it was illegal to sink merchant vessels 


\section{AMERICA'S CASE AGAINST GERMANY}

without warning. But the United States apparently took no advantage of the admission thus made. Furthermore, Germany professed herself willing to accept the expedient of having agencies designated by the United States to receive imports of food stuffs, but "the enemy Governments would have to permit the free entry into Germany of the raw material mentioned in the free list of the Declaration of London and to treat materials included in the list of conditional contraband according to the same principles as food and foodstuffs." This, of course, did not begin to meet the American proposal and was calculated to force a relaxation of the British measures to intercept Germany's trade. One cannot but marvel again at the ineptness of the German diplomacy. Surely half a loaf was better than none. The damage done by the use of mines for offensive purposes and submarines for attacks on merchant vessels was for months negligible; and full compliance with the suggestion concerning food stuffs would have served somewhat to conciliate American opinion and could have forced the United States to protest much more vigorously 
against Great Britain's disregard of the principles of the Declaration of London. Instead, there came what was practically an invitation that the Allies in their turn refuse the suggestions, but the note did not fail to point out again that the hardships on neutrals would be lessened if "some way could be found to exclude the shipping of munitions of war from neutral countries to belligerents on ships of any nationality.", 7

As I have already said, the Germain reply was such as to demand a refusal on the part of Great Britain and this came on March 13th. The opportunity was taken, however, for a statement regarding the position of the Allies. Attention was called to the treatment by Germany of civil-

7 The misrepresentation of the German reply as an acceptance of the American proposals has not been confined to Ambassador Bernstorff and the German Foreign Office. In the Senatorial debate on the War Resolution, for example, Senator La Follette said: "Without quoting at length the replies of the Governments of Germany and Great Britain, it is sufficient to say that under date of March 1, 1915 [the communication bears the date of February 28th], the German Government replied substantially acceding to the proposition made by the Government of the United States, and on March 15 [March 13th] the British Government replied substantially refusing to accede to our request."' Congressional Record, 65th Cong., 1st Sess., p. 300 (April 4, 1917). See below, p. 74 n. 


\section{AMERICA'S CASE AGAINST GERMANY}

ians in Belgium and the North of France; to inhumanities with regard to prisoners; the laying of mines on the high seas; the destruction, without warning, of British merchant vessels; the naval bombardment of unfortified towns, and the dropping of bombs on the east coast of England, where there were no strategic points to be attacked. Only two criticisms, on the other hand, had been made concerning British action. It was true that mines had been laid, but they became harmless when adrift and had not been resorted to until weeks after the discovery of the German practice.

As for the stoppage of foodstuffs the points of international law were not argued, but this important consideration was adverted to:

"Inasmuch as the stoppage of all foodstuffs is an admitted consequence of blockade, it is obvious that there can be no universal rule based on considerations of morality and humanity, which is contrary to this practice. The right to stop foodstuffs destined for the civil population must, therefore, in any case be admitted if an effective 'cordon' controlling intercourse with the enemy is drawn, announced, and maintained. Moreover, independently of rights arising from belligerent action in the nature of blockade, 
some other nations, differing from the opinion of the Governments of the United States and Great Britain, have held that to stop the food of the civil population is a natural and legitimate method of bringing pressure to bear on an enemy country, as it is upon the defense of a besieged town."

Prince Bismarck and Count Caprivi were quoted to show that such a measure "presumably is not repugnant to German morality." The latter said, for example, in the German Reichstag that "the private introduction of provisions into Paris was prohibited during the siege, and in the same way a nation would be justified in preventing the import of food and raw produce." And the practice of the Union during the American Civil War could also be cited to witness the weakness of the German complaint.

The British object, finally, would be attained without

"sacrificing neutral ships or noncombatant lives, or inflicting upon neutrals the damage that must be entailed when a vessel and its cargo are sunk without notice, examination, or trial.

"I must emphasize again that this measure is a 


\section{AMERICA'S CASE AGAINST GERMANY}

natural and necessary consequence of the unprecedented methods, repugnant to all law and morality, which have been described above, which Germany began to adopt at the very outset of the war, and the effects of which have been constantly accumulating."

Thus ended the preliminary exchanges between the United States and Germany. Submarines were already being used against merchant vessels; noncombatants were losing their lives; the measure was, by German admission, in violation of the existing rules of law, although she claimed that it was justified to meet the measures of her enemies, and asked that neutrals relinquish their rights in order not to suffer; but no American citizens were killed, and the United States refrained from entering any further protest on humanitarian grounds. Germany had been told that she would be held to a "strict accountability," and she had answered that she would endeavor to respect neutral rights, but that with the trade in munitions continuing, she would not be responsible for any unfortunate accidents. It was now a question 
of how soon American rights would be directly infringed. ${ }^{8}$

- Before March 10, 1915, eighty-eight British merchant vessels were captured or destroyed. Fifty-four of these were taken by cruisers, twelve were sunk by mines, and twenty-two were victims of the submarine warfare. The gross tonnage was 309,945 . This, however, did not begin to affect England seriously for in the same period the arrivals and departures of overseas steamers of all nationalities of more than 300 tons were 4,745. The New York Times Current History, Vol. II, p. 20 (April, 1915). 


\section{CHAPTER III}

SOME POINTS OF INTERNATIONAL LAW

IT has already been indicated briefly how Germany's submarine warfare did not achieve even a remote compliance with the principles of international law defining a blockade, and that, therefore, neutral vessels could be captured only for the carriage of contraband. The German plea that any war measure, with the purpose of starving her into submission was per se illegal has been mentioned. This will be returned to later when it will be necessary to consider in some detail the objections to the trade in munitions and the attempt to justify the submarine outrages on the ground that they were a proper retaliation for England's extensions of international law. But here it may be appropriate to direct attention to three problems of international law which were in- 
volved by these preliminary exchanges: The status of the Declaration of London, the limitations (which are of fundamental importance) on the right to destroy enemy and neutral merchant vessels, and the use of neutral flags on enemy ships.

The purpose of the Declaration of London, which was signed by ten powers (Germany, Austria-Hungary, Spain, France, Great Britain, the United States, Italy, Japan, the Netherlands and Russia) was twofold: It was designed in the first place to furnish the rules to govern the International Prize Court-provided for by the Second Hague Peace Conference but never brought into existence-in determining appeals from national prize courts in time of war; and secondly, it was intended to codify the rules of maritime warfare, the assumption being that the approval of these ten powers would lead to its acceptance by the other nations. To some extent this hope was not unjustified since, although neither state had ratified the instrument, it was proclaimed as the rule of conduct during the Italian-Turkish war; but in the present con- 


\section{AMERICA'S CASE AGAINST GERMANY}

flict it has been more honored in the breach than in the observance.

Although the London Naval Conference was called by Great Britain, which extended the invitation to the other nine maritime powers, a prize bill, incorporating the provisions of the Declaration was rejected by the House of Lords after it had passed the Commons (1911). Public opinion in Great Britain was unfavorable to it-particularly those provisions dealing with contraband. The United States Senate, however, ratified the Declaration and both Germany and France incorporated it in their naval codes. Upon the outbreak of the present war, the United States inquired of all the belligerents as to whether they would agree that the Declaration should be applicable upon condition of reciprocity, and expressed the belief "that an acceptance of the laws by the belligerents would prevent grave misunderstandings which may arise as to the relations between neutral powers and belligerents."' Germany and Austria-Hungary expressed their willingness, but Great Britain refused to abide by a number of provisions, the most important being those which de- 
fined contraband and limited the doctrine of continuous voyage to absolute contraband. Consequently, on October 22nd, the United States notified all the belligerents that the sugggestion was withdrawn and expressed the intention of the Government to "insist that the rights and duties of the United States and its citizens in the present war be defined by the existing rules of international law and the treaties of the United States irrespective of the Declaration of London." Actions of the belligerents, therefore, could not be deemed illegal simply because they traversed the provisions of the Declaration of London.

The importance which Germany attached to the refusal of England to abide by the Declaration of London may be attributed to two of the English war measures which the Declaration forbade. In the first place, England at once exercised the right which every belligerent in previous wars had asserted-to make up her own lists of absolute and conditional contraband-and as is the case each time, the measure favored her own rights at the expense of the interests of opponents and neutrals. There was 
nothing illegal about this, ${ }^{1}$ and although she put on her list articles which the London Declaration declared not to be contraband, she violated no international rule since the Declaration of London is not binding. Furthermore, as has already been indicated, there is a distinction between kinds of contraband, the classic division being threefold: (1) articles primarily used for military purposes in time of war; (2) articles of use for warlike or peaceful purposes, and (3) articles of no utility except for purposes of peace. If consigned to the belligerent country, articles of absolute contraband are considered as meant for the enemy forces, while articles of conditional contraband are liable to capture if intended for the armed forces, and this can be shown by their consignment to agents of the government or to naval and military stations. In two respects changed circumstances have made this distinction largely illusory : easy means of transportation by which articles landed at an unfortified port, some distance from the military forces, can be speedily

${ }^{1}$ Articles 23 and 25 of the Declaration expressly recognized the right to extend the lists of both kinds of contraband. 
devoted to war-like purposes, and, secondly, the organization of a country-such as was effected by the decree of the German Bundesrath-so that all food supplies and available resources are under the control of the Government and no distinction can be made between the peaceful and war-like purposes of imported articles.

The British Orders in Council, in addition to extending lists of contraband, ignored the distinction between the two kinds. But, more than that, they applied the doctrine of continuous voyage to shipments of conditional contraband. The Anglo-American practice, largely incorporated in the Declaration of London, permits the capture of absolute contraband of war, when destined for a neutral port if the ultimate destination of the cargo is a belligerent country. But this doctrine of continuous voyage, first applied in the French courts during the Crimean War, much extended, as is well known -and as England reminded us with her later consent-during the American Civil War, and used by Great Britain during the Boer War, relates only to absolute contraband and according to the Declaration of London may not apply 
46 AMERICA'S CASE AGAINST GERMANY

to shipments of conditional contraband. This distinction also, Great Britain made largely illusory, directly through the interference with articles of conditional contraband consigned to neutrals, and indirectly through the extension of the absolute contraband lists. The power of the British navy was used practically to license commerce between the United States and neutrals like the Netherlands, Norway, Sweden, and Denmark, and in order to continue to trade with America these countries were compelled to prohibit the export of articles which Great Britain would not allow to be imported with the possibility that they might find their way into the territory of her enemies.

This rather summary statement, explains, I think, the nature of the first British extensions of international law which Germany claimed gave her license to retaliate by submarine warfare. The extensions were forbidden by the. Declaration of London, and strict adherence to this instrument would have been greatly to the advantage of Germany, since she could have had more direct trade with the United States and 
could have imported commodities of American origin from the adjacent neutral countries. But since, unratified as it was, the Declaration of London was not binding, it had no sacrosanct character, and the importance given it in the German communications should be taken as attaching to the recognized principles of international law which the Declaration sought to, and in large part did, codify.

The German war zone decree asserted the right to destroy all enemy merchant ships found in the restricted area, and the sinking of neutral vessels, the intimation was given, might in some cases be unavoidable. It becomes pertinent to inquire, therefore, as to the right of destruction of enemy and neutral vessels by a belligerent power as defined by undisputed rules of international law.

It is not likely that the proclamation was intended to include all enemy ships, for at the Second Hague Peace Conference the powers agreed to a Convention (Number XI) limiting the right of capture in maritime warfare and 


\section{8 \\ AMERICA'S CASE AGAINST GERMANY}

exempting "vessels charged with religious, scientific, or philanthropic missions," and "vessels used exclusively for fishing along the coast or small boats employed in local trade" so long as they take no part in hostilities. Hospital ships were also exempted by the Geneva Conventions, and if international law prohibits capture, destruction is obviously illegal. While there have been instances in the present war of the destruction by German submarines of vessels thus exempted, it is more pleasant to assume that their initial threat meant to make these exceptions. ${ }^{2}$

In other cases, however, the right to destroy enemy prizes is admitted, although it is equally well recognized that, if possible, they should be brought into a prize court to have the legality of the capture determined. Some authorities have disapproved of the practice as barbarous; the German publicists Bluntschli and Heffter admitted it only in cases of absolute necessity, and Perels denied it until the prize court had determined the right of ownership. In recent wars the practice has been indulged in and its

'When submarine depredations began under the decree of January 31, 1917, no exceptions were made. See above, p. 9. 
legality seems to be beyond doubt, ${ }^{3}$ but it is subject to a fundamental limitation: the destruction cannot take place unless the safety of the passengers and crew is assured. An able authority-Professor James W. Garner-who has made an exhaustive investigation of the literature on the subject, asserts that no international law authority, admiralty court, or government (through prize regulations) has ever asserted a "right to destroy merchant vessels under any and all circumstances and subject to no restrictions. The universal opinion is that destruction is permissible only in certain exceptional cases and always subject to the observance of certain rules by the captor." 4 In every case the persons on board must be saved together with their baggage. The various Prize Codes-even that of the Imperial German Government-recognize this fundamental limitation.

In addition, the Prize Codes do not recognize

${ }^{3}$ In the Spanish American War three Spanish merchant ships were sunk by an American cruiser but the United States claimed that the vessels were transports.

"Garner, "International Law in the European War: War Zones and Submarine Warfare," American Journal of International Law, Vol. IX, pp. 594, 616. 


\section{AMERICA'S CASE AGAINST GERMANY}

an otherwise unlimited right of destruction. The American regulations permit it if there are controlling reasons why the prize may not be sent in for adjudication such as "unseaworthiness, the existence of infectious diseases, or the lack of a prize crew" or "imminent danger of recapture." The British code is similar, but both stipulate that the ship's crew and papers are to be removed; and where the obligation to safeguard the lives of noncombatants is not expressly affirmed, it is understood. Furthermore, there are two international agreements on the subject.

The Convention (Number VI) adopted at the Second Hague Conference to define the status of enemy merchant ships at the outbreak of hostilities declares that vessels on the high seas in ignorance of the outbreak of hostilities cannot be confiscated, but they are liable to detention, requisition, or even destruction, upon payment of compensation, "but in such cases provision must be made for the safety of the persons on board as well as the security of the ship's papers," and the specific statement of the rule in this instance is simply an affirmation of 
the general doctrine. Again, the Convention (Number XI) restricting the right of capture provides that when an enemy merchant ship is taken by a belligerent the neutrals in the crew cannot be made prisoners of war, and the same rule applies if the nationals of the enemy state make a formal promise, in writing, "not to undertake, while hostilities last, any service connected with the operations of the war." This, it hardly need be said, definitely negatives the right to take noncombatant lives. Finally, at the Second Hague Conference the American delegation pointed out that there were not adequate facilities on warships to care for persons taken from vessels that had been destroyed, and that apart from this such persons would be exposed to the dangers of naval battles. This was urged against the right of destruction, but, "In all the discussions on the subject, it was assumed that the right of destruction was conditioned upon the obligation of the captor to provide for the safety of the crews and passengers, and never once was it intimated that inability to make such provision constituted a sufficient 
defense against disregard of the obligation.", 5 It is, then, to repeat, not the destruction of enemy prizes which is unlawful, and although this might, contrary to previous practice, be illegally done in every case by the submarines, there would be nothing wanton or uncivilized about it; the failure to regard the sacred immunities of noncombatants is what condemns the German methods.

So far as neutral prizes are concerned, the same principles apply, although much more rigorously. Up until the 19 th century, there were no instances of the destruction of neutral vessels, and the first exercise of the right other than sporadically was during the Russo-Japanese War. This was authorized by the Russian prize code in exceptional cases only, however, after the commander " has taken off all persons on board, and as much of the cargo as possible, and arranged for the safety of the vessel's papers and any other objects which may be necessary for throwing light on the case at the inquiry to be instituted in accordance with the procedure in prize cases." No distinction was

${ }^{\circ}$ Garner, op. cit., p. 626. 
made between enemy and neutral vessels, but after Great Britain protested, the Russian regulations were modified so as to permit the destruction of the latter only in the "direst necessity.",

The naval codes of a number of other maritime powers admitted the destruction in very exceptional cases of ships which were liable to condemnation (for carrying contraband, breach of blockade, etc.), and upon this question an agreement was reached in the Declaration of London, which allowed destruction in cases of "exceptional necessity"--if taking the vessel into port "would involve danger to the safety of the warship or to the success of the operations in which she is engaged at the time" ; but before the vessel may be destroyed "all persons on board must be placed in safety and all the ship's papers and other documents which the parties interested consider relevant for the purpose of deciding on the validity of the capture must be taken on board the warship" (Articles 49 and 50).

This was apparently satisfactory to Germany 


\section{AMERICA'S CASE AGAINST GERMANY}

as her delegates signed the Declaration and she professed herself willing to accede to it at the beginning of the war. In fact, a German memorandum on the subject, presented to the Conference, was identical with the article as finally agreed upon, and the German Prize Code of 1909. published on August 3, 1914, recognized the right of destruction with terms but little broader than those of the Declaration of London. ${ }^{6}$ In short, this maritime war measure, of recent origin, of legality that has been denied by authoritative writers and important states, is not unlimited; but there is universal agreement that the lives of those on board must be safeguarded, whether enemy or belligerent.

Official notice was taken by the United States of the German complaint that the British Government had authorized the use of the neutral flag as a ruse de guerre, the particular incident cited being the action of the captain of the Lusitania in raising the American flag as the vessel

- Secretary Lansing's Lusitania note of June 9th reminded the Imperial Government of the code which had been issued providing that "before destruction all persons on board, if possible with their personal effects, are to be placed in safety." 
approached the British coast in order to escape an attack by a German submarine. ${ }^{7}$

Secretary Bryan reserved the question of legality, and while admitting the propriety of the occasional use of the flag in order to deceive an approaching enemy, objected to the "explicit sanction by a belligerent government for its merchant ships generally to fly the flag of a neutral power within certain portions of the high seas which are presumed to be frequented with hostile warships." This, he continued, "jeopardizes the vessels of the neutrals visiting those waters in a peculiar degree by raising the presumption that they are of belligerent nationality regardless of the flag which they may carry. ...

"A policy such as the one which his Maj-

${ }^{7}$ On February 7th the British Foreign Office issued a memorandum in which it was said that the use of a neutral flag is, with certain limitations, established as a valid ruse de guerre. "The only effect in the case of a merchantman of wearing a flag other than her national flag is to compel the enemy to follow the ordinary obligations of naval warfare, and to satisfy himself as to the nationality of the vessel and the character of the cargo by examination before eapturing her and taking her into a Prize Court for adjudication . . . No breach of international law is thereby committed." There were, furthermore, several instances in the early days of the war of the use by German vessels of neutral flags. 


\section{AMERICA'S CASE AGAINST GERMANY}

esty's Government is said to intend to adopt, would, if the declaration of the German Admiralty is put in force, it seems clear, afford no protection to British vessels, while it would be a serious and constant menace to the lives and vessels of American citizens." A failure to comply with this request would "impose upon the Government of Great Britain a measure of responsibility for the loss of American lives and vessels in case of an attack by a German naval force."'s

The practice of using the neutral flag was formerly quite common, and warships are permitted to assume colors other than their own, so long as they raise their true flags before going into action. Great Britain's reply, made on February 19th, said that the British shipping act permitted the use of the British flag by foreign merchant vessels for the purpose of escaping capture; that other nations had similar legislation; that Union merchant ships during the American Civil War had availed themselves

${ }^{8}$ This protest (February 10th) is an additional indication that the American "strict accountability" note of the same day was more concerned with the safety of American vessels than with the safety of American citizens on enemy vessels. 
of this privilege, and that it would be unreasonable to expect the British Government to enact legislation forbidding the use of foreign flags by her vessels. In the case of the Lusitania American passengers had requested that the flag be raised and this was done without any advice from the Government. The communication then proceeded to state correctly certain fundamental principles of international law:

"Now that the German Government have announced their intention to sink merchant vessels at sight, with their noncombatant crews, cargoes, and papers, a proceeding hitherto regarded by the opinion of the world not as war, but as piracy, it is felt that the United States Government could not fairly ask the British Government to order British merchant vessels to forego the means-always hitherto permitted-of escaping not only capture but the much worse fate of sinking and destruction. ...

"The obligation upon a belligerent warship to ascertain definitely for itself the nationality and character of a merchant vessel before capturing it, and a fortiori before sinking and destroying it, has been universally recognized. If that obligation is fulfilled, hoisting a neutral flag on board a British vessel ean not possibly endanger neutral shipping; and the British Government hold that if loss to neutrals 
is caused by disregard of this obligation, it is upon the enemy vessel disregarding it and upon the Government giving orders that it should be disregarded that the sole responsibility for injury to neutrals ought to rest."

This is a perfectly accurate statement of the recognized international rules. If the flag of the United States was never used as a ruse de guerre, American interests could not be involved, through "an unfortunate mistake" by the submarine warfare. But the rules, not only of international law but also of humanity, put war vessels under an obligation to examine a merchant ship before capturing it, and in case exceptional circumstances justify its destruction, to put the passengers and crew in places of safety before this may be done. Germany has no right to sink an English merchant vessel without warning and without safeguarding the lives of noncombatants, and one cannot, therefore, reach any conclusion other than that the abandonment by British ships of the use of the American flag would make it possible for Germany to violate international law with impunity, so far as American interests were con- 
cerned, except in cases where American property or citizens were on board of the British ship. And if British insistence upon the right to use the American flag would contribute to compelling the submarine to make an examination and to take care of the passengers and crew in order not to affect neutrals, then it was justified on this basis, apart from its legality. The ground of the German protest, to repeat, was that the submarines should be permitted to violate international law with reduced chances of affecting the United States; and the ground of the American protest was that by the relinquishment on the part of British ships of the use of the American flag the chances of American interests being affected would be more remote. 


\section{CHAPTER IV}

THE "LUSITANIA" AND OTHER OUTRAGES

American rights were first infringed on March 28th when the British steamer Falaba was sunk by a German submarine and an American citizen-Leon C. Thrasher-was drowned. Just a month later, the American ship Cushing was attacked by a German aeroplane, but no loss of life was occasioned. On May 1st, however, the American vessel Gulflight was torpedoed by a submarine and three American citizens met their death. Finally, on May 7 th, the Lusitania was sunk without warning, and more than one thousand innocent men, women and children were killed, more than one hundred of them being American citizens.

The United States and Germany had already had some correspondence over the sinking, on January 27th, of the American ship William $P$. Frye by the German auxiliary cruiser Prinz 
THE "LUSITANIA"-OTHER OUTRAGES 61

Eitel Frederick. A bill, claiming the value of the ship and some compensation for damages occasioned by its sinking (the personal effects of the captain, etc.), was presented on April $3 \mathrm{~d}$ and Germany very promptly replied (April 4th) assuming liability for the claim. I have referred above to her interesting but inconsistent attitude in justifying the destruction of this vessel with a cargo of wheat on practically the same grounds as those taken by Great Britain in claiming the right to detain foodstuffs going into Germany. But the phases of the case pertinent here are that Germany asserted that since the auxiliary cruiser was unable to take the vessel into port, the sinking was justified under the Declaration of London, and in accordance with the German Prize Code and Article 50 of that instrument, "the duties devolving" upon the cruiser before the destruction of the ship," as to the safety of the persons on board and the ship's papers were fulfilled. In the second place, Germany admitted that she was liable for damages under Article 13 of the Prussian-American treaty of friendship and commerce of July 11, 1799, taken in connection with 
Article 12 of the Prussian-American treaty of commerce and navigation of May 1, 1828.

These stipulations, which were called to the attention of the United States by Germany, are very remarkable. The treaty of 1828 revived certain clauses in the treaties of 1785 and 1799 which provided that American citizens may trade with Germany's enemies "as in full peace" and this would seem to estop Germany from protesting against the trade in munitions. Under the treaties, no articles in American vessels "shall be deemed contraband, so as to induce confiscation or condemnation and a loss of property to individuals." Nevertheless, Germany has the right to detain such vessels, subject to a reasonable compensation for loss to the proprietors, and is allowed to use the military stores upon payment of compensation. "But in the case supposed of a vessel stopped for articles of contraband, if the master of the vessel stopped will deliver out the goods supposed to be of contraband nature, he shall be admitted to do it, and the vessel shall not in that case be carried into any port, nor further detained, but shall be allowed to proceed on her 
voyage." Two points of controversy arose: as to the manner of settling the amount of damages and as to the nature of Germany's liability.

The United States, in view of the fact that the treaty was involved, objected to adjudication by a German prize court but insisted on arbitration, and Germany agreed to this in principle. The other important difference was that the United States claimed that the sinking of the Frye violated the treaty, but Germany asserted that under the treaty the sinking was justified subject to the payment of compensation. In either event, however, the treaty provisions are applicable to submarine warfare and give the United States a claim for damages even in those cases where the destruction of a neutral prize would be justified by the Declaration of London. Whether the treaty permits destruction or simply imposes liability, it does prohibit any indiscriminate warfare which would be directed against American vessels, and more than that, it expressly denies the legality of sinking without 
saving the noncombatants on board, for Article 15 provides :

"And to prevent entirely all disorder and violence in such cases, it is stipulated that when the vessels of the neutral party, sailing without convoy, shall be met by any vessel of war, public or private, of the other party, such vessel of war shall not send more than two or three men in their boat on board the said neutral vessel, to examine her passports and documents. And all persons belonging to any vessel of war, public or private, who shall molest or insult in any manner whatever the people, vessels, or effects of the other party, shall be responsible in their persons and property, for damages and interest, sufficient security for which shall be given by all commanders of private armed vessels before they are commissioned."

America's case against the use of submarines by Germany, however, was rested upon general principles of international law and the dictates of humanity, and in the correspondence these treaties are not stressed. But it may be remarked here that a submarine "blockade" applying to American ships cannot but violate these old instruments the binding character of which Germany admitted on her own initiative. 
After the sinking of the Lusitania and before an American protest could be made, two communications were received from Germany. The first expressed "deepest sympathy at the loss of lives on board the Lusitania," but maintained that the responsibility rested with the British Government, which, through its plan of starving the civilian population of Germany, had forced Germany to resort to retaliatory measures. The practice of arming British vessels made it impossible to treat them as merchant ships; and Germany regretted "that Americans felt more inclined to trust to English promises than to pay attention to warnings from the German side.". In the second communication, Germany explained her policy with respect to neutral ships in the "war zone." Instructions had been issued to avoid attacks on neutral vessels under all circumstances. "Even when such ships have contraband of war on board they are dealt with by submarines solely according to the rules of international law applying to prize warfare." In the event of an unfortunate accident regret would be expressed and damages afforded, and when 


\section{AMERICA'S CASE AGAINST GERMANY}

there was a dispute as to the facts, Germany was willing to submit the questions to an International Commission of Inquiry as provided by the Hague Convention for the Pacific Settlement of International Disputes.

The protest of the United States was sent to Germany on May 13th, after six days' deliberation by President Wilson. It referred in perhaps too fulsome terms to "the humane and enlightened attitude hitherto assumed by the Imperial German Government in matters of international right," and declared that

"having understood the instructions of the Imperial German Government to its naval commanders to be upon the same plane of humane action prescribed by the naval codes of other nations, the Government of the United States was loath to believe-it cannot now bring itself to believe-that these acts, so absolutely contrary to the rules, the practices, and the spirit of modern warfare, could have the countenance or sanction of that great Government. It feels it to be its duty, therefore, to address the Imperial German Government concerning them with the utmost frankness and in the earnest hope that it is not mistaken in expecting action on the part of the Imperial German Government which will correct the unfortunate im- 
THE "LUSITANIA"-OTHER OUTRAGES 67

pressions which have been created and vindicate once more the position of that Government with regard to the sacred freedom of the seas."

Germany had already been informed that the United States could not consent to "an abbreviation of the rights of American shipmasters or of American citizens bound on lawful errands as passengers on merchant ships of belligerent nationality" through the adoption of " methods of retaliation which go much beyond the ordinary methods of warfare at sea," and that the Imperial German Government would be held "to a strict accountability for any infringement of those rights, intentional or incidental." The United States, the note continued,

"does not understand the Imperial German Government to question those rights. It assumes, on the contrary, that the Imperial Government accept, as of course, the rule that the lives of noncombatants, whether they be of neutral citizenship or citizens of one of the nations at war, can not lawfully or rightfully be put in jeopardy by the capture or destruction of an unarmed merchantman, and recognize also, as all other nations do, the obligation to take the usual precaution of visit and search to ascertain 


\section{8 AMERICA'S CASE AGAINST GERMANY}

whether a suspected merchantman is in fact of belligerent nationality or is in fact carrying contraband of war under a neutral flag.

"The Government of the United States, therefore, desires to call the attention of the Imperial German Government with the utmost earnestness to the fact that the objection to their present method of attack against the trade of their enemies lies in the practical impossibility of employing submarines in the destruction of commerce without disregarding those rules of fairness, reason, justice, and humanity which all modern opinion regards as imperative. It is practically impossible for the officers of a submarine to visit a merchantman at sea and examine her papers and cargo. It is practically impossible for them to make a prize of her; and, if they can not put a prize crew on board of her, they can not sink her without leaving her crew and all on board of her to the mercy of the sea in her small boats. These facts, it is understood the Imperial German Government frankly admit. We are informed that in the instances of which we have spoken time enough for even that poor measure of safety was not given, and in at least two of the cases cited not so much as a warning was received. Manifestly submarines can not be used against merchantmen, as the last few weeks have shown, without an inevitable violation of many sacred principles of justice and humanity." 
Particular attention should be given the italicized clauses, for they marked a position which President Wilson abandoned in later exchanges, namely, that submarines should not be used against commerce at all, but that their operations should be confined to war vessels. Had this position thus asserted-and based, although perhaps vaguely, on the rights of humanity, of all noncombatants rather than simply American citizens-been maintained, the case of the Government would have been stronger and the regrettable controversy over armed merchantmen would probably not have arisen. Nevertheless, while in some places a vindication of public right and a condemnation of the illegal character of the German measures no matter what noncombatant nationals were affected, the note laid greatest stress upon the "indisputable rights" of American citizens to travel

"wherever their legitimate business calls them upon the high seas, and exercise those rights in what should be the well-justified confidence that their lives will not be endangered by acts done in clear violation of universally acknowledged international obligations, 


\section{AMERICA'S CASE AGAINST GERMANY}

and certainly in the confidence that their own Government will sustain them in the exercise of their rights."

The advertisement of the German Embassy, appearing in the newspapers before the liner sailed and warning Americans to keep away from the war zone, was referred to as a communication of "surprising irregularity" and it was pointed out

"that no warning that an unlawful and inhumane act will be committed can possibly be accepted as an excuse or palliation for that act or as an abatement of the responsibility for its commission.

"Long acquainted as this Government has been with the character of the Imperial German Government and with the high principles of equity by which they have in the past been actuated and guided, the Government of the United States can not believe that the commanders of the vessels which committed these acts of lawlessness did so except under a misapprehension of the orders issued by the Imperial German naval authorities. It takes it for granted that, at least within the practical possibilities of every such case, the commanders even of submarines were expected to do nothing that would involve the lives of noncombatants or the safety of neutral ships, even at the cost of failing of their object of capture or 
destruction. It confidently expects, therefore, that the Imperial German Government will disavow the acts of which the Government of the United States complains, that they will make reparation so far as reparation is possible for injuries which are without measure, and that they will take immediate steps to prevent the recurrence of anything so obviously subversive of the principles of warfare for which the Imperial German Government have in the past so wisely and so firmly contended."

And the note closed with the following strong paragraphs :

"Expressions of regret and offers of reparation in case of the destruction of neutral ships sunk by mistake, while they may satisfy international obligations, if no loss of life results, can not justify or excuse a practice, the natural and necessary effect of which is to subject neutral nations and neutral persons to new and immeasurable risks.

"The Imperial German Government will not expect the Government of the United States to omit any word or any act necessary to the performance of its sacred duty of maintaining the rights of the United States and its citizens and of safeguarding their free exercise and enjoyment."

Germany's reply was made on May 28th. It disclaimed, first, with regard to the Cushing 


\section{AMERICA'S CASE AGAINST GERMANY}

and Gulflight any intention to attack neutral vessels; explicit instructions had been given to the contrary and if these vessels came to grief through no fault of their own, "regret" would be expressed and indemnification promised if the facts justified it. ${ }^{1}$ In the case of the Falaba the submarine commander intended to give the passengers and crew an opportunity to save themselves, but when the English captain sent up rockets for help, warning was given that the ship would be sunk in ten minutes, and actually, it was claimed, twenty-three minutes were allowed.

With regard to the loss of life on the Lusitania, Germany, it was said, had already expressed regret to the neutral governments whose nationals had been killed. Important facts in connection with the Lusitania, however, had escaped the attention of the United

${ }^{1}$ A communication concerning the Gulfight and Cushing was sent to Washington three days later. The Gulfight had no neutral markings, was apparently accompanied by two British convoy ships, and the American flag was not noticed until the moment of attack. "According to the attendant circumstances there can be no doubt that the attack is not attributed to the fault of the commander, but to an unfortunate accident." Regret was expressed and compensation promised to American citizens who sustained damage. 
States, and these Germany proceeded to state: The Lusitania was a large and fast commerce steamer, constructed with government funds as an auxiliary cruiser; when she left New York, guns were on board, mounted under the decks and masked; furthermore, in view of the instructions of the British Admiralty that merchant vessels should attack submarines by ramming them,

"the Imperial Government is unable to consider English merchant vessels any longer as 'undefended territory' in the zone of maritime war designated by the Admiralty Staff of the Imperial German Navy, the German commanders are consequently no longer in a position to observe the rules of capture otherwise usual and with which they invariably complied before this. Lastly, the Imperial Government must specially point out that on her last trip the Lusitania, as on earlier occasions, had Canadian troops and munitions on board, including no less than 5,400 cases of ammunition destined for the destruction of brave German soldiers who are fulfilling with self-sacrifice and devotion their duty in the service of the Fatherland. The German Government believes that it acts in just self-defense when it seeks to protect the lives of its soldiers by destroying ammunition destined for the enemy with the means of war at its command. 


\section{AMERICA'S CASE AGAINST GERMANY}

The English steamship company must have been aware of the dangers to which passengers on board the Lusitania were exposed under the circumstances. In taking them on board in spite of this the company quite deliberately tried to use the lives of American citizens as protection for the ammunition carried, and violated the clear provisions of American laws which expressly prohibit, and provide punishment for, the carrying of passengers on ships which have explosives on board. The company thereby wantonly caused the death of so many passengers. According to the express report of the submarine commander concerned, which is further confirmed by all other reports, there can be no doubt that the rapid sinking of the Lusitania was primarily due to the explosion of the cargo of ammunition caused by the torpedo. Otherwise, in all human probability, the passengers of the Lusitania would have been saved."

A final statement of the German position was reserved until a reply could be received from the United States after it had made an examination of these facts. ${ }^{2}$

${ }^{2}$ The astounding statement is made that Germany had furnished "ample evidence of its good will by its willingness to consider" the proposals of the United States to Great Britain and Germany for mutual concessions to secure an international modus vivendi, but that "the realization of these proposals failed, as is known, on account of their rejection by the Government of Great Britain." A similar illusion seems to have 
THE "LUSITANIA"-OTHER OUTRAGES 75

This, of course, did not so much as attempt to traverse the American contention that the sinking of the Lusitania was an illegal, wanton act and it ignored the main points of the American note: that submarines could be used against commerce only in violation of international law and the dictates of humanity, and that reparation should be made and promises given for the future. Germany treated the two cases of the Gulfight and Cushing more at length in a separate communication, dated June 1st. The attack by the submarine on the former was "an unfortunate accident," due to mistaken identity, and full recompense would be furnished for damage done American citizens. As for the Cushing, this case had not yet been fully investigated but the attack was not "aimed at any American ship."

The reply of the American Government made on June 9th noted with satisfaction "the full recognition by the Imperial German Governpossessed Ambassador Bernstorff. In a memorandum which he presented on the question of armed merchantmen (March 8, 1916), he said: "Germany, on March 1, 1915, declared her willingness to comply with the proposal of the American Government." But, as the reader of the original note can easily discover, Germany did nothing of the sort. (See above, p. $33 \mathrm{ff}$.) 


\section{AMERICA'S CASE AGAINST GERMANY}

ment, in discussing the cases of the Cushing and the Gulflight, of the principle of the freedom of all parts of the open sea to neutral ships and the frank willingness of the Imperial German Government to acknowledge and meet its liability where the fact of attack upon neutral ships 'which have not been guilty of any hostile act' by German aircraft or vessels of war is satisfactorily established.' Information regarding the Cushing was promised in due course and then the note proceeded to discuss the real issue and show the inadequacy and evasion of the German reply:

"With regard to the sinking of the steamer Falaba, by which an American citizen lost his life, the Government of the United States is surprised to find the Imperial German Government contending that an effort on the part of a merchantman to escape capture and secure assistance alters the obligation of the officers seeking to make the capture in respect of the safety of the lives of those on board the merchantman, although the vessel had ceased her attempt to escape when torpedoed. These are not new circumstances. They have been in the minds of statesmen and of international jurists throughout the development of naval warfare, and the Government of the 
United States does not understand that they have ever been held to alter the principles of humanity upon which it has insisted. Nothing but actual forcible resistance or continued efforts to escape by flight when ordered to stop for the purpose of visit on the part of the merchantman has ever been held to forfeit the lives of her passengers or crew. The Government of the United States, however, does not understand that the Imperial German Government is seeking in this case to relieve itself of liability, but only intends to set forth the circumstances which led the commander of the submarine to allow himself to be hurried into the course which he took."

In the case of the Lusitania, it was the duty of the United States, as in every clearance of a merchant vessel from American ports, to see that there was no armament for offensive purposes, that she was not serving as a transport, that her cargo was not illegal under American statutes, and that she was not in fact a British auxiliary vessel. This duty was carried out, and the United States could say that the Imperial German Government had been misinformed. The contention regarding the carriage of contraband and its explosion was irrelevant 
in considering the legality of the German methods for

"The sinking of passenger ships involves principles of humanity which throw into the background any special circumstances of detail that may be thought to affect the cases, principles which lift it, as the Imperial German Government will no doubt be quick to recognize and acknowledge, out of the class of ordinary subjects of diplomatic discussion or of international controversy. Whatever be the other facts regarding the Lusitania, the principal fact is that a great steamer, primarily and chiefly a conveyance for passengers, and carrying more than a thousand souls who had no part or lot in the conduct of the war, was torpedoed and sunk without so much as a challenge or a warning, and that men, women, and children were sent to their death in circumstances unparalleled in modern warfare. The fact that more than 100 American eitizens were among those who perished made it the duty of the Government of the United States to speak of these things and, once more with solemn emphasis, to call the attention of the Imperial German Government to the grave responsibility which the Government of the United States conceives that it has incurred in this tragic occurrence, and to the indisputable principle upon which that responsibility rests. The Government of the United States is contending for something much 
greater than mere rights of property or privileges of commerce. It is contending for nothing less high and sacred than the rights of humanity, which every Government honors itself in respecting and which no Government is justified in resigning on behalf of those under its care and authority. Only her actual resistance to capture or refusal to stop when ordered to do so for the purpose of visit could have afforded the commander of the submarine any justification for so much as putting the lives of those on board the ship in jeopardy. This principle the Government of the United States understands the explicit instructions issued on August 3, 1914, by the Imperial German Admiralty to its commanders at sea to have recognized and embodied, as do the naval codes of all other nations, and upon it every traveler and seaman had a right to depend. It is upon this principle of humanity as well as upon the law founded upon this principle that the United States must stand."

This measured indictment of the German policy of frightfulness seems to protest against all submarine warfare, even where American citizens are not actually affected, and while there is no recurrence to the contention of the first Lusitania note, that the submarine should not be used against commerce at all, there is no intimation that this contention has been de- 
parted from. The note goes on to acknowledge the expression of willingness on the part of Germany to reach an agreement with Great Britain, but meanwhile "confidently looks to see the justice and humanity of the Government of Germany vindicated in all cases where Americans have been wronged or their rights as neutrals invaded," and "very earnestly and very solemnly renews the representations" of its first note which had not been answered.

"The Government of the United States," it was said in conclusion, "cannot admit that the proclamation of a war zone from which neutral ships have been warned to keep away may be made to operate as in any degree an abbreviation of the rights either of American shipmasters or of American citizens bound on lawful errands as passengers on merchant ships of belligerent nationality. It does not understand the Imperial German Government to question those rights. It understands it, also, to accept as established beyond question the principle that the lives of noncombatants can not lawfully or rightfully be put in jeopardy by the capture or destruction of an unresisting merchantman, and to recognize the obligation to take sufficient precaution to ascertain whether a suspected merchantman is in fact of belligerent nationality or is in fact carrying contraband 
of war under a neutral flag. The Government of the United States therefore deems it reasonable to expect that the Imperial German Government will adopt the measures necessary to put these principles into practice in respect of the safeguarding of American lives and American ships, and asks for assurances that this will be done." 3

\section{The first half of the German reply (July 8th)}

\section{to this second Lusitania note, was taken up}

${ }^{3}$ The resignation of the then Secretary of State, Mr. Bryan, rather than sign this note, is an incident of personal and domestic importance rather than of international significance. He was anxious, it will be remembered, to employ the principle of investigation embodied in his thirty peace treaties (although there was no dispute that more than a thousand noncombatants were killed), and meanwhile to prevent Americans from traveling on belligerent ships or on American ships carrying contraband. In the third place he wanted our case against Great Britain pushed much more strongly. He explained his signing of the first note, which is a much more vigorous communication, on the ground that it presented the plaintiff's case; when this was not accepted, he desired to recede gracefully.

There are probably many phases of this whole incident that have not been made public. After Mr. Bryan resigned, the noto was softened (the change has not been published) but in his judgment it was not sufficient. During the eampaign of 1916 there was some talk of a mysterious postscript to conciliate Germany that was deleted just before transmission. Also, a full explanation has never been given of Mr. Bryan's interview with the Austro-Hungarian Ambassador who was told that the first Lusitania note was for "home consumption." But with the exception of the possible effects of this interview, the incident is of only domestic interest. 
with a protest against British trade restraints and the refusal to ratify the Declaration of London. There was a hint of justification on the basis of Realpolitik when the reply said: "It is the sacred duty of the Imperial Government to do all within its power to protect and to save the lives of German subjects. If the Imperial Government were derelict in these, its duties, it would be guilty before God and history of the violation of those principles of highest humanity which are the foundation of every national existence."

In the case of the Lusitania, there was the same evasion of the issue that had characterized the previous statements. Its destruction was declared to show "with horrible clearness to what jeopardizing of human lives the manner of conducting the war employed by our adversaries leads." If the commander of the submarine. which destroyed the Lusitania had given the crew and passengers time to leave the ship before torpedoing it, this would have meant the destruction of his own vessel. Furthermore, it was to be anticipated that such a ship would remain above water for a sufficient 
time to allow an escape to be made, and the explosive character of the cargo was responsible for the failure of this expectation. Again, it was "pointed out that if the Lusitania had been spared thousands of cases of ammunition would have been sent to Germany's enemies, and thereby thousands of German mothers and children robbed of their supporters," the argument, here, apparently being that American and English mothers and children could be murdered on the supposition that the vessel contained war material.

Promises were made, however, that American shipping would be respected, and the suggestion was offered that the vessels be marked so as to be easily recognizable. It was "confidently" hoped "that the American Government will assume the guarantee that these vessels have no contraband on board," and the details of their unhampered passage would have to be agreed upon by both belligerents. Perhaps it would be possible for a reasonable number of neutral steamers to be put under the American flag and thus "adequate facilities for travel across the Atlantic Ocean can be 


\section{AMERICA'S CASE AGAINST GERMANY}

afforded American citizens. There would therefore appear to be no compelling necessity for American citizens to travel to Europe in time of war on ships carrying an enemy flag. In particular, the Imperial Government is unable to admit that American citizens can protect an enemy ship through the mere fact of their presence on board." 4

${ }^{4}$ The note said that if it should not be possible to acquire neutral steamers, "the Imperial Government is prepared to interpose no objections to the placing under the American flag by the American Government of four enemy passenger steamers for the passenger traffic between America and England. The assurances of 'free and safe' passage for American passenger steamers would then be extended to apply under the identical pre-conditions to these formerly hostile passenger ships. . . .

"Germany merely followed England's example when it declared part of the high seas an area of war. Consequently accidents suffered by neutrals on enemy ships in this area of war ean not well be judged differently from aceidents to which neutrals are at all times exposed at the seat of war on land, when they betake themselves into dangerous localities in spite of previous warning."

Perhaps the German Foreign Office believed that such communications would serve to palliate the American people; but certainly Ambassador Bernstorff was under no such delusion. The first note was published in the papers on May 31st and there was an outburst of criticism. Count Bernstorff asked for and secured an interview with the President and obtained permission to send to Germany a member of the Embassy staff who traveled under a safe conduct arranged for by the State Department (June 3rd). There was much difficulty, the Ambassador said, in communicating by cable; but it would not 
As was the case with the first German reply on the Lusitania tragedy, this note was followed by an unexpected communication designed to conciliate American opinion and persuade the country that the submarine campaign would be directed only against enemy merchant vessels and that there was some fairness in the contention that Americans should not be used to protect such vessels, particularly if they carried contraband of war. Submarine activities had apparently continued with but slight, if any restraint, for on May 25th, the American steamer Nebraskan, bound for Delaware Breakwater was torpedoed 45 miles off the south coast of Ireland. The crew at once took to the boats, but the vessel had been struck forward and did not sink, so the crew was able to take her back to Liverpool. No submarine was seen, but the circumstances of the explosion, and fragments of metal found in the hull of the Nebraskan indicated that the vessel had not struck a mine.

seem that the Embassy's representative (Dr. Anton MeyerGerhard) contributed much towards making the note of July 8 th more satisfactory. 
On July 12th Ambassador Gerard sent to the State Department Germany's admission that the Nebraskan had been attacked by a submarine. No formal protest had been made, but when "the German Government received from newspaper reports the intelligence" of the incident, it "started a thorough investigation without delay." Germany asserted that the vessel had no markings, that the submarine commander was therefore justified in assuming that it was an English steamer, but that when, sometime after the torpedo was fired, the Nebraskan hoisted the American flag, further attack was refrained from.

"It results from this, without a doubt, that attack on the steamer Nebraskan was not meant for the American flag; nor is it traceable to any fault on the part of the commander of the German submarine, but is to be considered an unfortunate accident. The German Government expresses its regret at the occurrence to the Government of the United States of America and declares its readiness to make compensation for the damage thereby sustained by American citizens.

"As in the case of the steamer Gulflight, the German Government begs to suggest that the American 
THE "LUSITANIA"-OTHER OUTRAGES 87

Government submit to it a detailed statement of such damage or, if doubt might arise as to certain points, to designate an expert to fix the amount of compensation, acting in conjunction with a German expert."

But, other cases occurred during the exchanges over the Lusitania which were so flagrant that it was but scant comfort to know that Germany was willing to make reparation for the Gulfight and the Nebraskan. American interests were directly affected when the British steamer Armenian was torpedoed off the Cornwall coast on June 28th, several Americans employed to care for the horses and mules of the vessel's cargo being killed. In this particular instance, however, the United States could not regard the sinking as an "unfriendly act," because the Armenian attempted to escape, and a chase of an hour ensued with the submarine shelling the vessel. The captain then surrendered, and after he and the crew had left the ship, it was torpedoed, the only exceptional feature on account of the nature of the submarine being that the crew had but the "poor security" of the open sea and were not taken on board of the capturing ves- 


\section{AMERICA'S CASE AGAINST GERMANY}

sel. Likewise, the British merchantman AngloCalifornian, on July 2nd, tried to escape from a submarine, the captain and several members of the crew being killed by shells, but wireless calls for help brought British destroyers to the scene and the submarine was forced to submerge. Again, three Americans were saved by the American bark Normandy when the Russian steamer Leo was sunk with no opportunity for saving lives. ${ }^{5}$

On July 9th, a repetition, although on a smaller scale, of the Lusitania outrage, was narrowly missed. The British steamship Orduna, bound west from Liverpool, with twentyone American passengers on board was attacked by a submarine. A torpedo cleared the stern by a margin of only ten feet and six shells were fired, but the Orduna was able to escape. ${ }^{6}$

- The charge was made that the submarine compelled the Normandy to act as a shield while the approach of the Leo was awaited. Associated Press Dispatch, dated July 13, 1915.

- The German explanation made on September 9 th and transmitted by Mr. Gerard on the 11th, said that the Orduna had no markings but that the first attack on her "by a torpedo was not in accordance with the existing instructions, which provide that large passenger steamers are only to be torpedoed after previous warning and after the rescuing of passengers and erew. The failure to observe the instructions was based on an error, which 
On July 25th, the American ship Leelanaw was sunk while flying the American flag, with no loss of life. Ample time was given the crew to leave the vessel and the submarine towed the life-boats for some distance. ${ }^{7}$

A few days before the news of this last incident came, Secretary of State Lansing sent his last formal communication on the Lusitania (July 21st). He called the German reply "very unsatisfactory" for instead of meeting the real differences it proposed arrangements which would set aside the principles of law

is at any rate comprehensible, and the repetition of which appears to be out of the question, in view of the more explicit instructions issued in the meantime. Moreover, the commanders of the submarines have been reminded that it is their duty to exercise greater eare and to observe carefully the orders issued."

${ }^{7}$ On October 16th, the German Foreign Office declared that the commander had acted in accordance with the prineiples of international law and that he was justified in sinking the vessel since more than one half of the eargo was absolute contraband (flax). The commander was unable to take the steamer into a port without impairing the success of his operations and was justified in destroying the vessel under the Declaration of London. However, in this case, as in that of the William $P$. Frye, the Treaty of 1799 was applicable, and the Prize Court would determine the amounts due the American owners. The reply of the United States (November 30th) insisted, as it had in the Frye ease, that the amount of the indemnity be determined by diplomatic negotiation. 


\section{AMERICA'S CASE AGAINST GERMANY}

and humanity for which the Government of the United States was contending. The Government of the United States noted with satisfaction, however,

"that the Imperial German Government recognizes without reservation the validity of the principles insisted on in the several communications which this Government has addressed to the Imperial German Government with regard to its announcement of a war zone and the use of submarines against merchantmen on the high seas-the principle that the high seas are free, that the character and cargo of a merchantman must first be ascertained before she can lawfully be seized or destroyed, and that the lives of noncombatants may in no case be put in jeopardy unless the vessel resists or seeks to escape after being summoned to submit to examination; for a belligerent act of retaliation is per se an act beyond the law, and the defense of an act as retaliatory is an admission that it is illegal."

This definitely narrowed the controversy until the German case was made to rest merely on the ground that the submarine blockade was justified as retaliatory for England's extensions of international law, and to such an argument the United States interposed a denial which, as will be seen later, was generally 


\section{sound, if too broad, although this is not to say} that the German contention should be accepted, even in part. ${ }^{8}$

${ }^{8}$ Anticipatory of a more detailed consideration later, it may be pointed out here, that the British Ambassador in a note of March 1, 1915, frankly justified England's more stringent measures as retaliatory for Germany's violations of international law; but it was promised that they would be enforced "without risk to neutral ships or to neutral or noneombatant life and in strict observance of the dictates of humanity." With regard to the German methods, there were the following pertinent remarks:

"The sinking of prizes is in itself a questionable act, to be resorted to only in extraordinary circumstances and after provision has been made for the safety of all the crew or passengers (if there are passengers on board). The responsibility for discriminating between neutral and enemy vessels, and between neutral and enemy cargo, obviously rests with the attacking ship, whose duty it is to verify the status and character of the vessel and eargo, and to preserve all papers before sinking or ever capturing it. So also is the humane duty of providing for the safety of the crews of merchant vessels, whether neutral or enemy, an obligation upon every belligerent. It is upon this basis that all previous discussions of the law for regulating warfare at sea have proceeded.

"A German submarine, however, fulfills none of these obligations. She enjoys no local command of the waters in which she operates. She does not take her captures within the jurisdiction of a prize court. She carries no prize crew which she ean put on board a prize. She uses no effective means of discriminating between a neutral and an enemy vessel. She does not receive on board for safety the crew and passengers of the vessel she sinks. Her methods of warfare are therefore entirely outside the scope of any of the international instruments regulating operations against commerce in time of war. The German declaration substitutes indiscriminate destruction for regulated capture." 


\section{AMERICA'S CASE AGAINST GERMANY}

"The Government of the United States is, however," the note said, "keenly disappointed to find that the Imperial German Government regards itself as in large degree exempt from the obligation to observe these principles, even where neutral vessels are concerned, by what it believes the policy and practice of the Government of Great Britain to be in the present war with regard to neutral commerce." Germany was told here, just as she was to be told more forcibly in connection with her qualified pledge after the sinking of the Sussex, ${ }^{9}$ that the conduct of other belligerents was irrelevant to a discussion of "grave and unjustifiable violations of the rights of American citizens by German naval commanders"; these "illegal and inhuman acts, however justifiable they may be thought to be against an enemy who is believed to have acted in contravention of law and humanity, are manifestly indefensible when they deprive neutrals of their acknowledged rights, particularly when they violate the right to life itself.

"If a belligerent can not retaliate against an ${ }^{\circ}$ See below, p. $173 \mathrm{ff}$. 
THE "LUSITANIA"—OTHER OUTRAGES 93

enemy without injuring the lives of neutrals, as well as their property, humanity, as well as justice and a due regard for the dignity of neutral powers, should dictate that the practice be discontinued."

The Government of the United States professed itself not unmindful of the fact that when the existing international rules were formulated, the nations did not have in view the use of submarines, and announced that it was "ready to make reasonable allowances for these novel and unexpected aspects of war at sea; but it can not consent to abate any essential or fundamental right of its people because of a mere alteration of circumstances. The rights of neutrals in time of war are based upon principle, not upon expediency, and the principles are immutable. It is the duty and obligation of belligerents to find a way to adapt the new circumstances to them."

Secretary of State Lansing then apparently took the position that submarines could be used against commerce with a regard for the principles of international law and humanity and thus abandoned the belief, expressed in the first 


\section{AMERICA'S CASE AGAINST GERMANY}

Lusitania note that no submarine activities against commerce should be resorted to. In a paragraph of doubtful accuracy he said:

"The events of the past two months have clearly indicated that it is possible and practicable to conduct such submarine operations as have characterized the activity of the Imperial German Navy within the so-called war zone in substantial accord with the accepted practices of regulated warfare. The whole world has looked with interest and increasing satisfaction at the demonstration of that possibility by German naval commanders. It is manifestly possible, therefore, to lift the whole practice of submarine attack above the criticism which it has aroused and remove the chief causes of offense." ${ }^{10}$

${ }^{10}$ Here he probably had reference to the attacks on the Armenian and Anglo-Californian both of which attempted to escape. But it would seem that the inapplicability of the submarine to warfare on commerce had been demonstrated by the "unfortunate accidents" of the Gulfight and Nebraskan, admitted by Germany, "accidents" which could not have happened in cruiser warfare according to the recognized principles of international law. The facts of the Orduna incident which appear to negative Secretary Lansing's position even more definitely did not become known until after the despatch of his note. In the second American Lusitania note, a paragraph with reference to the Falaba correctly said that an effort to escape did not alter the obligation to safeguard the lives of those on board the merchantman. The force used could only be sufficient to check the flight or overcome the resistance. See above, p. 51 and below, p. 159 . 
Finally, the German Government was again called upon to disavow "the wanton act of its naval commander in sinking the Lusitania," and to offer "reparation for the American lives lost so far as reparation can be made for a needless destruction of human life by an illegal act." The suggestion regarding vessels under the American flag which would have free passage in the war zones was rejected since "the very agreement would, by implication, subject other vessels to illegal attack and would be a curtailment and therefore an abandonment of the principles for which this Government contends and which in times of calmer counsels every nation would concede as of course." And this solemn warning was conveyed:

"The very value which this Government sets upon the long and unbroken friendship between the people and Government of the United States and the people and Government of the German nation impels it to press very solemnly upon the Imperial German Government the necessity for a scrupulous observance of neutral rights in this critical matter. Friendship itself prompts it to say to the Imperial Government that repetition by the commanders of German naval vessels of acts in contravention of those rights 
must be regarded by the Government of the United States, when they affect American citizens, as deliberately unfriendly."

This, as I have said, was the final formal word of the United States on the Lusitania; further negotiations, to be referred to later, were conducted by means of "conversations" between the German Ambassador and the Secretary of State. But in the meantime a repetition, on a smaller scale, of the Lusitania tragedy brought the crisis to a head and wrung concessions and pledges, although limited, from the Imperial German Government. ${ }^{11}$

${ }^{11}$ The British Admiralty announced on May 18th that the submarine campaign had sunk 460,628 tons of British merchant and fishing vessels. This had caused the death of about 1556 persons. "On the other hand, no enemy or neutral subject had lost his life in consequence of the destruction by the English of enemy merchant vessels. Moreover, British warships had saved from drowning more than 1200 members of the crews of German warships destroyed, whereas no members of British crews had been saved by the Germans." Quoted by Garner, "International Law in the European War," American Journal of International Law, Vol. IX, p. 607. 


\section{CHAPTER V}

THE GERMAN PLEDGES

IN defense of her action in sinking the Lusitania Germany had alleged, among the various reasons to which from time to time she resorted, that the vessel was carrying contraband, and that, in order to prevent innocent women and children from being widowed and orphaned, she was justified in taking any measures to stop such a cargo before it reached her enemy. The Arabic, however, permitted no such "defense," for this White Star Liner was bound for New York and hence carrying no contraband, was unarmed, and was torpedoed without warning (August 19th), twenty-five of the crew and nineteen passengers being reported missing, among them two Americans. Here, certainly, it seemed, was the "deliberately unfriendly" act referred to in the last American note.

That Germany and her Ambassador in this 
country recognized the seriousness of the incident is shown by the instructions which Count Bernstorff received from Berlin and which he made public on August 24th. In the absence of official information, the statement said,

"The German Government trusts that the American Government will not take a definite stand at hearing only the reports of one side, which, in the opinion of the Imperial Government, cannot correspond with the facts, but that a chance will be given to Germany to be heard equally.

"Although the Imperial Government does not doubt the good faith of the witnesses whose statements are reported by the newspapers in Europe, it should be borne in mind that these statements are naturally made under excitement which might easily produce wrong impressions.

"If Americans should actually have lost their lives, this would naturally be contrary to our intentions. The German Government would deeply regret the fact, and begs to tender sincere sympathies to the American Government."

And, realizing that American public opinion would tolerate no more evasions, pleas of "unfortunate accidents," or further justification of the submarine warfare as a measure of reprisal, 
the Imperial Government authorized Ambassador Bernstorff to convey to the United States formal assurances that the outrages would be stopped. This was done in the following note, addressed to Secretary Lansing and dated September 1st:

"My Dear Mr. Secretary:

"With reference to our conversation of this morning I beg to inform you that my instructions ${ }^{1}$ concerning our answer to your last Lusitania note contain the following passage:

“ 'Liners will not be sunk by our submarines without warning and without safety of the lives of noncombatants, provided that the liners do not try to escape or offer resistance.'

"Although I know that you do not wish to discuss the Lusitania question till the Arabic incident has been definitely and satisfactorily settled, I desire to inform you of the above because this policy of my Government was decided on before the Arabic incident occurred.

"I have no objection to your making any use you may please of the above information.

"I remain, etc.,

\section{"J. BernstorfF."}

${ }^{1}$ The exchange of formal notes had ceased and the Lusitania case was being discussed by the Ambassador and the State Department. 


\section{AMERICA'S CASE AGAINST GERMANY}

Commenting on this letter, Secretary of State Lansing said:

"In view of the clearness of the foregoing statement, it seems needless to make any comment in regard to it, other than to say that it appears to be a recognition of the fundamental principle for which we have contended."

But subsequent events showed that this comment by Secretary Lansing was too optimistic.

The German excuse for the sinking of the Arabic (made on September 7 th) was that the commander thought

"that the steamer had the intention of attacking and ramming him. In order to anticipate this attack he gave orders to have the submarine submerge and fired a torpedo at the steamer. After firing he convinced himself that the people on board were being rescued in fifteen boats.

"According to his instructions the commander was not allowed to attack the Arabic without warning and without saving lives unless the ship attempted to escape or offered resistance. $\mathrm{He}$ was forced to conclude from the attendant circumstances that the Arabic planned a violent attack on the submarine. This conclusion is all the more obvious, as he had been fired upon at a great distance in the Irish Sea 
on August 14-that is, a few days before-by a large passenger steamer apparently belonging to the British Royal Mail Steam Packet Company, which he had neither attacked nor stopped.

"The German Government most deeply regrets that lives were lost through the action of the commander. It particularly expresses this regret to the Government of the United States on account of the death of American citizens."

Germany refused to acknowledge any obligation to grant indemnity, even if the commander was mistaken, but offered to submit this phase of the incident to the Hague Tribunal. This position, while marking from the standpoint of the United States a qualified diplomatic victory, was far from satisfactory, and serious doubt was thrown on the bona fides of the German pledges by the torpedoing of the Hesperian. This liner was sunk on September 4th with the loss of twenty-six lives, and the incident aided in impressing on the United States the need for a very definite understanding with Germany. ${ }^{2}$

${ }^{2}$ On September 14th a semi-official statement of the German position asserted that the disaster must have been caused by a mine. "According to a pre-arranged distribution," it was not 


\section{AMERICA'S CASE AGAINST GERMANY}

Another month of negotiation ensued, and then the Arabic crisis was apparently settled. On October 5th the German Ambassador notified the State Department that the instructions to the submarine commanders had been "made so stringent that the recurrence of incidents similar to the Arabic case is considered out of the question.

"According to the report of Commander Schneider of the submarine that sank the Arabic, and his affidavit as well as those of his men, Commander Schneider was convinced that the Arabic intended to ram the submarine. On the other hand, the Imperial Government does not doubt the good faith of the affidavits of the British officers of the Arabic, according to which the Arabic did not intend to ram the submarine. The attack of the submarine, therepossible for a German submarine to be in that vicinity when the Hesperian sank; and the statement elaimed, further, that "the explosion, according to descriptions received from British sources, was of such a nature as to indicate from its effects that it was rather of a mine than of a torpedo." The British Admiralty forwarded to the State Department fragments of metal picked up on the deck which American naval experts declared were parts of a torpedo. This decision was announced by the State Department on October 30th. The case against Germany, on account of this incident, however, was not pressed. 
fore, was undertaken against the instructions issued to the commander. The Imperial Government regrets and disavows this act and has notified Commander Schneider accordingly.

"Under these circumstances my Government is prepared to pay an indemnity for American lives which to its deep regret have been lost on the Arabic. I am authorized to negotiate with you about the amount of this indemnity.", 3

This result of the Arabic incident seemed to indicate that Germany was alarmed over the danger of a break with the United States. "A diplomatic victory for the United States" was the description given by Count von Bernstorff and the concessions now secured after the stringent announcement of February 4 th included the following, as set forth in a semiofficial statement: (1) an acknowledgment of the right of American ships to sail through the

${ }^{3}$ Ambassador Bernstorff in a note to the State Department on September 4th reported the action of an English merchant vessel in firing on a submarine without a challenge of any kind and stressed "the point that British merchant vessels which attack German submarines of course expose themselves to the danger of destruction; American citizens who travel on such vessels do so on their own responsibility and incur the greatest risk." 


\section{AMERICA'S CASE AGAINST GERMANY}

war zone; (2) an acknowledgment of liability for American ships damaged or sunk, even when carriers of contraband, this liability arising, however, under the Treaty of 1799 and not under general principles of international law; (3) a promise not to sink American ships carrying conditional contraband; (4) an offer to arbitrate the German claim that American ships carrying absolute contraband might be sunk (the Frye case) ; (5) an acknowledgment of liability for damages to American citizens on merchant ships, even those of the enemy, when the attack was without warning and with no resistance or attempt to escape; (6) a promise not to attack "liners" even when enemy ones, without allowing time for the escape of the passengers and crew; (7) a disavowal of the sinking of the Arabic and an expression of regret at the incident; (8) a promise that in the future a mistake by a submarine commander in thinking that he was to be attacked would not be regarded as diminishing liability for damages to American citizens. ${ }^{4}$

4 On October 30th the German Foreign Secretary in a communication to Ambassador Gerard, noted "with satisfaction that a full understanding has been reached between our two 
Unquestionably the United States had won a great diplomatic victory. The war party in Germany and a majority of the people seemed to be convinced of the righteousness of the submarine warfare, and of the pro-English, unreasonable character of the threats of the United States, veiled, to be sure, but nevertheless very real, that the continuance of friendly relations was contingent upon an abandonment of such methods. However, even these pledges afforded reasons for doubt about the future. While no official announcement was made, apparently authentic reports were to the effect that the British had been very successful in destroying German submarines, and perhaps the Imperial Government was willing to make pledges, which would prevent a crisis for the time being, until new submarines could be constructed. The word "liners" was ambiguous, and ensuing incidents would inevitably cause a debate over its meaning. President Wilson's

Governments"-with particular reference to the Arabic incident. He repeated Count Bernstorff's statement that " the attack of the submarine to our regret, was not in accordance with their instructions issued, and that the commander has been notified accordingly.", 
106 AMERICA'S CASE AGAINST GERMANY

address to Congress on the Sussex case indicated that he did not consider it to include more than passenger vessels, and there was thus left open the question of American seamen on British vessels which carried no passengers. More than that, the measure of safety which would be afforded noncombatants in case a liner was sunk without warning was undefined and, although a month later, Germany did indicate her conception of the duties imposed upon her submarines, the Arabic pledges left this question open.

The communication to which I refer was sent on November 29th (although not published until January 8, 1916) and related to the settlement of the Frye case. It contained these paragraphs, pertinent to the submarine controversy and corroborative of the German pledges:

"Until the decision of the permanent court of arbitration, the German naval forces will sink only such American vessels as are loaded with absolute contraband, when the pre-conditions provided by the Declaration of London are present.

"In this the German Government quite shares the view of the American Government that all possible 
care must be taken for the security of the crew and passengers of a vessel to be sunk. Consequently, the persons on board of a vessel may not be ordered into her lifeboats except when the general conditions, that is to say, the weather, the condition of the sea, and the neighborhood of the coasts afford absolute certainty that the boats will reach the nearest port. For the rest, the German Government begs to point out that in cases where the German naval forces have sunk neutral vessels for carrying contraband no lass of life has yet occurred."

And in a communication dated September 9, 1915 (but not published until October 29th), the German Foreign Office asserted that the American bark Normandy, from New York to Liverpool with a cargo of lumber, "was permitted to continue her voyage unhindered, as it was impossible to guarantee that the crew would be surely rescued in the small boats if the ship were sunk.", 5

These statements were reassuring. The Lusitania case had not been settled, but there

${ }^{5}$ This communication explained the attack on the Orduna. See above, p. 88. The Normandy also figured in the submarine operations when, it was charged, she was used as a shield during an attack on the Russian ship Leo. See above, p. 88 . 
were no further outrages by submarines, and in view of the concessions already secured, the Administration probably feared that it would seem too insistent if, by reason of potential dangers, it pressed for definitions. More than that, an admission had been obtained that the legal position taken by the United States was unassailable, and the German argument had been boiled down to her assertion in the Lusitania note of May 28th, that the Imperial Government acted "in just self-defense when it seeks to protect the lives of its soldiers by destroying munitions destined for the enemy with the means of war at its command." The disavowal of the Arabic and the pledges, although not entirely satisfactory, seemed to clear the way for a settlement of the Lusitania controversy between Ambassador Bernstorff and Secretary Lansing. 


\section{CHAPTER VI}

THE TRADE IN MUNITIONS OF WAR

IN the communications from the German Government to the United States concerning the war zone decree and submarine blockade which have already been referred to, there occur occasional references to the extensive trade in munitions of war carried on by American citizens. Thus, in the German reply to President Wilson's "strict accountability" note of February 10th, attention was directed "very particularly and with the greatest emphasis" to the fact "that a trade in arms exists between American manufacturers and Germany's enemies which is estimated at many hundred million marks." No formal breach of neutrality was charged, but Germany professed herself "at a great disadvantage through the fact that the neutral powers have hitherto achieved no success or only an unmeaning success in their 


\section{AMERICA'S CASE AGAINST GERMANY}

assertion of the right to trade with Germany, acknowledged to be legitimate by international law, whereas they make unlimited use of their right to tolerate trade in contraband with England and our other enemies. Conceded that it is the formal right of neutrals not to protect their legitimate trade with Germany and even to allow themselves knowingly and willingly to be induced by England to restrict such trade, it is on the other hand not less their good right, although unfortunately not exercised, to stop trade in contraband, especially the trade in arms, with Germany's enemies."

The same argument was made by the German Ambassador in a memorandum which he presented to the State Department on April 4, 1915. After complaining against the British trade restrictions and asserting that the lack of success on the part of the United States in securing a relaxation of the measures taken justified the assumption that the violations of international law were acquiesced in, he adverted to the attitude of the United States on the munition question. Here consideration should be given not only to the formal aspect of the case 
but also to "the spirit in which neutrality is carried out." He recognized that an obvious retort was that in previous wars Germany had supplied arms to belligerents, but the situation now was different, for, he said, "then it was not a question whether war material should be supplied to the belligerents, but who should supply it in competition with other nations. In the present war all nations having a war material industry worth mentioning are either involved in the war themselves or are engaged in perfecting their own armaments, and have therefore laid an embargo against the exportation of war material. The United States is accordingly the only neutral country in a position to furnish war materials. The conception of neutrality is thereby given a new purport, independently of the formal question of hitherto existing law. In contradiction thereto, the United States is building up a powerful arms industry in the broadest sense, the existing plants not only being worked but enlarged by all available means, and new ones built. The international conventions for the protection of the rights of neutral nations doubtless sprang 


\section{AMERICA'S CASE AGAINST GERMANY}

from the necessity of protecting the existing industries of neutral nations as far as possible from injury in their business. But it can in no event be in accordance with the spirit of true neutrality if, under the protection of such international stipulations, an entirely new industry is created in a neutral state, such as is the development of the arms industry in the United States, the business whereof, under the present conditions, can benefit only the belligerent powers."

Assuming a theoretical willingness to supply Germany, the case would not be altered. If America desired a true neutrality, the United States could prevent this one-sided trade or at least utilize the weapon which it offered, and by declaring an embargo protect legitimate trade with Germany, particularly in foodstuffs, it being probable that Great Britain could thus be made to acquiesce. Finally, the memorandum requested that the spirit of " genuine neutrality" that had actuated the United States in putting an embargo on the shipment of arms to Mexico should dictate a similar policy in 
this instance. The position of the Administration had already been stated very definitely.

Orders were received by American manufacturers soon after the war began, and on October 15 th, in response to requests as to the legality of the traffic, the State Department issued a memorandum which informed the contractors that they were at liberty to meet any demands, subject to the risk that, if intercepted, the goods could be confiscated and destroyed. The first official complaint against the attitude of the United States, or rather against the activities of the manufacturing firms, came on December 8th, when Count Bernstorff charged that the English army was using dumdum bullets, furnished by an American company. The State Department replied a month later, refusing to consider the charges, and transmitting categorical denials from the companies that they had made any war implements the use of which was not permitted by international law. ${ }^{1}$

Meanwhile, the State Department had taken

${ }^{1}$ This and several other paragraphs in this chapter are taken from an article entitled "The American Congress and the Export of War Munitions", which I contributed to the Contemporary Review for December, 1915. 


\section{AMERICA'S CASE AGAINST GERMANY}

a position which, in the opinion of a good many able international lawyers, while commendable for its motive, was too far advanced. The Department advised the Bethlehem Steel Company that the construction of submarine parts for England, to be assembled after delivery, would be a violation of the Hague provision that neutrals may not fit out and arm war vessels for a belligerent. This opinion was at the request of the President of the Steel Company, and did not follow any formal protest. Nevertheless the Administration's apparent willingness to be too strict led the German Ambassador on January 18 th to protest that the construction of hydro-aeroplanes was a violation of the same provision. To this the Secretary of State replied as follows:

"As to the assertion of the character of the hydro-aeroplanes, I submit the following comments: The fact that a hydro-aeroplane is fitted with apparatus to rise from and alight upon the sea does not, in my opinion, give it the character of a vessel any more than the wheels attached to an aeroplane fitting it to rise from and alight upon land give the latter the charac- 
THE TRADE IN MUNITIONS OF WAR 115

ter of a land vehicle." "The answer of the Secretary of State was a nugget of gold in the dry pages of diplomatic correspondence," says a recent writer. "Presumably, if conditions were reversed, and the British were protesting hydro-aeroplanes which were being shipped to Germany, the ingenious German Ambassador would contend that the machines had asbestos fittings on their wings and hence were to be classed as fireflies." 2

The American position on the general question was restated in January when Secretary of State Bryan issued, in the form of a letter to Senator Stone, a denial of current charges that the United States, in observing neutrality, had been unfriendly to Germany and Austria-Hungary. This letter, written by Mr. Lansing, referred to the sales by German manufacturers during the Russo-Japanese War, and quoted a memorandum of the Imperial Government in which it was said that "under the general principles of international law, no exception can be taken to neutral states, letting war material go to Germany's enemies from or through neu-

${ }^{2}$ Clapp, Economic Aspects of the War, pp. 296-297. 
116 AMERICA'S CASE AGAINST GERMANY

tral territory." In the United States, however, those who for various reasons desired an embargo, were on the increase both in number and in power, so the German Government was encouraged to continue the discussion, not so much on the legal principle, as in relation to our controversy with Great Britain, and there followed the German communication of February 16th and the Ambassador's memorandum of April 4th.

President Wilson himself is said to have written the reply to the latter and it was in the nature of a rebuke. He declared, first of all, that the "relations of the two Governments with one another cannot wisely be made a subject of discussion with a third Government, which cannot be fully informed as to the facts, and which cannot be fully cognizant of the reasons for the course pursued." That the United States had ever yielded any of its rights to one of the belligerents was vigorously denied; and the note expressed surprise that Count Bernstorff had not referred to the attempt to secure mutual concessions from the belligerents, not as of right but as a friend of 
both parties. The attempt was unsuccessful since Germany, as I have pointed out, gave but a very limited approval, and President Wilson regretted "that your Excellency did not deem it worthy of mention in modification of the impressions you expressed.', The note concluded with the following statement:

"This Government holds, as I believe Your Excellency is aware, and as it is constrained to hold in view of the present indisputable doctrines of international law, that any change in its own laws of neutrality during the progress of a war which would affect unequally the relations of the United States with the nations at war would be an unjustifiable departure from the principles of strict neutrality by which it has consistently sought to direct its actions, and I respectfully submit that none of the circumstances urged in Your Excellency's memorandum alters the principle involved. The placing of an embargo on the trade in arms at the present time would constitute such a change and be a direct violation of the neutrality of the United States. It will, I feel assured, be clear to Your Excellency that, holding this view and considering itself in honor bound by it, it is out of the question for this Government to consider such a course." 3

a"A neutral Power is not bound to prevent the export or transit, for the use of either belligerent, of arms, ammunitions, 


\section{AMERICA'S CASE AGAINST GERMANY}

This position was in exact consonance with the traditional American attitude which need not be discussed in any great detail. The legality of the traffic has been maintained without exception. It was first asserted during the Napoleonic Wars, when, in its efforts to preserve a strict and impeccable neutrality, the United States was confronted by problems, which, comparatively, were more important than those of the present, for the period was one in which the fundamental principles of neutrality were being slowly, but definitely shaped. To a memorial protesting against shipments to France, Jefferson answered "that our citizens have always been free to make, vend, and export arms; that it is the constant occupation and livelihood of some of them. To suppress their callings, the only means, perhaps, of their subsistence, because a war exists in foreign and

or, in general, of anything which could be of use to an army or fleet." (Article 7).

" ... these rules should not, in principle, be altered, in the course of the war, by a neutral Power, except in a case where experience has shown the necessity for such change for the protection of the rights of that power.' (Preamble.) Convention (XIII) Concerning the Rights and Duties of Neutral Powers in Naval War, Hague Conference, 1907. 
distant countries, in which we have no concern, would scarcely be expected. It would be hard in principle and impossible in practice." Carried to its logical conclusion, the theory of an embargo would necessarily be extended to cover conditional contraband. As Secretary Seward told the Mexican Minister in 1862: "If Mexico shall prescribe to us what merchandise we shall not sell to French subjects, because it may be employed in military operations against Mexico, France must equally be allowed to dictate to us what merchandise we shall allow to be shipped to Mexico, because it might be belligerently used against France. Every other nation which is at war would have a similar right, and every other commercial nation would be bound to respect it as much as the United States. Commerce in that case, instead of being free or independent, would exist only at the caprice of war.' Such has been the consistent American position, grounded in law and strengthened by strong considerations of policy, not only for the specific reasons enumerated by Mr. Seward, but for others that will be adverted to presently. 


\section{AMERICA'S CASE AGAINST GERMANY}

Three incidents in the diplomatic history of the United States, however, have been made much of to justify the claim of those desiring an embargo, that such a measure would not be a departure from all precedent; that, in fact, the United States belongs to the company of belligerents, who, during almost every war, have entered protests against munitions being sent to their enemies by the citizens of a neutral nation. First of all, it is argued that the socalled French Arms debate in the United States Senate following the Franco-Prussian War showed that we had violated our duties as a neutral, and that the speech made upon this occasion by Carl Schurz was a protest against such conduct. But the question at issue in that debate was not, as the advocates of an embargo frequently allege, whether we had helped the French with arms and ammunition; on the contrary, it was whether the United States had been defrauded and officials had profited by the sale to France of arms owned but discarded by the United States Government. There are a good many ramifications to the incident, but it is clear that there is no parallel to present con- 
ditions. The War Department, moreover, when it learned the destination of the arms, offered Prussia the privilege of buying the same number upon the same terms, but the proposal was declined, and Prussia added that she had no objection to the continuance of shipments to the French. The debate in the Senate was upon the responsibility for the sales and there was no mention of the condition which exists at present, namely, the transactions being conducted by private individuals who manufacture the munitions which they furnish.

The second incident used to charge inconsistency against the United States is that, during the Spanish-American War, the American Ambassador to Germany requested the German Government to take "vigorous steps" to prevent the shipment of even small arms from Germany to Spain. The citation was mentioned by Count Bernstorff when he gave out his memorandum of protest on April 4th, but that he attaches no great importance to the incident is shown by the fact that it does not figure in any of his official communications. Nevertheless, in 


\section{AMERICA'S CASE AGAINST GERMANY}

garbled forms, and often twisted to the bare statement that the United States solemnly protested, the story has been worked pretty hard. The facts have been made public by the American State Department.

"It appears," says the Department's account, "that on May 18, 1898, Ambassador Andrew D. White received a telephonic message from the American consul at Hamburg that the Spanish ship Pinzon would sail within an hour for Cardiff to take on a cargo of coal for a Spanish port; that a part of the message was indistinct, and that it could not be clearly understood whether the ship was or was not liable to seizure on other grounds. The Ambassador, therefore, not desiring to incur delay by asking explanations went immediately to the Foreign Office and asked for the arrest and search of the vessel, and it was promised that everything possible should be done.

"On the next morning the Ambassador received a telegram from the American consul that the Pinzon when passing Cuxhaven the preceding night was searched for war contraband by order of the German Chancellor, but that nothing was found."

If the matter had ended there, the United States could hardly have been accused of departing from its traditional and consistently adhered to policy of permitting the export of 


\section{THE TRADE IN MUNITIONS OF WAR 123}

arms, and of not objecting to the same attitude on the part of foreign governments. But when news of the incident reached the State Department, Ambassador White was, on June 6, 1898, sent the following instruction:

"In view of the reported action of the Imperial German Government in directing the search of the Pinzon for contraband of war, the Department desires to be advised whether there are any laws or regulations in force which forbid the shipment of contraband of war from Hamburg or any other German port. It is assumed that you can obtain such information without applying to the German Government for it. It is important that if any such laws or regulations exist this Government and its agents may be informed of them, so as to avoid the embarrassments which might arise, if it should appear to protest on the general principles of international law against neutral governments allowing articles regarded merely as contraband of war to be shipped from their ports."

In reply to this instruction, which was almost a reproof, Mr. White later informed the State Department that there were no laws on the subject; the German Government had issued no proclamation of neutrality, and the Reichstag 


\section{AMERICA'S CASE AGAINST GERMANY}

had not discussed the subject of contraband since 1894. Comment of my own upon this incident would be useless. When the incomplete account given by Mr. White in his Autobiography (Chap. XVI, p. 168) is amplified by the facts of the State Department's memorandum, the United States is shown once more to have asserted its belief in the legality and policy of munition shipments by a neutral.

More convincing, however, at least at first glance, is the precedent cited by the German Ambassador in his memorandum of April 4ththat the United States placed an embargo on the export of arms and munitions to Mexico. But the conditions which made such action seem advisable were entirely exceptional. The struggle in Mexico was between two civil factions and menaced the peace of the United States. While the enforcement of an embargo could not of itself restore order, there was a reasonable hope that it would reduce the extent and duration of the conflict, and in any event, the policy of the measure must be considered in the light of the peculiar relations between the United States and Latin American coun- 
THE TRADE IN MUNITIONS OF WAR 125

tries, and not as dictated, or even permitted, by the general principles of international law. In fact, the executive order of the President raising the embargo (issued on February 3, 1914, when there was no likelihood that a European War would soon present the question of restrictive measures) declared the original order to have been "a departure from the accepted practice of neutrality." It is submitted, therefore, that even were conditions similar, this admission would prevent the Mexican policy from being quoted as a binding precedent.

Such, then, are the incidents in the diplomatic history of the United States that were used by those desiring an embargo; and it is difficult to see how any conclusion can be reached, other than that the traditional attitude of the United States has been to permit its citizens freely to export arms and ammunition to one or all of the belligerents. President Wilson's reply to Count Bernstorff's memorandum was entirely appropriate from the standpoint of the consistent policy of the United States, her interests, and the rules of international law.

Germany's record of sales of munitions in 


\section{AMERICA'S CASE AGAINST GERMANY}

previous wars, which she confessed but avoided as binding precedents in view of changed conditions, made it inadvisable for her to file any formal remonstrance and so this was left for the Austro-Hungarian Government which on June 29, 1915, sent the United States a protest against the continued trade in munitions. It was true, the note said, that under the Hague Conventions the traffic was legal, and that the rules of international law could not be altered during a war except when necessary for the protection of the rights of the neutral. But,

"According to all authorities on international law who concern themselves more particularly with the question now under consideration, a neutral government may not permit traffic in contraband of war, to be carried on without hindrance when this traffic assumes such a form or such dimensions that the neutrality of the nation becomes involved thereby."

And the suggestion was made that the United States might very well,"confront the opponents of Austria-Hungary and Germany with the possibility of the prohibition of the exportation of foodstuffs and raw materials" in order to compel Great Britain to rescind her illegal meas- 
ures and to nullify "the wanton efforts of the enemies of Austria-Hungary and Germany to use hunger as an ally.",

Now, apart from the suggestion as to our controversy with Great Britain the only point of any importance in this communication is that which attempts--as Count Bernstorff's memorandum did-to assert a quantitative norm as determining whether the munitions trade can go on in accordance with true neutrality. This distinction was supported by Bluntschli and one or two other German jurists; it has never received anything approaching general support, and has in fact received its strongest condemnation from German writers on international law, the vast majority of whom, as Secretary Lansing pointed out in his reply to the AustroHungarian communication, pronounce the traffic unexceptionally legal. From the standpoint of accepted international rules, this criterion is novel f from the standpoint of ethical obligation, it would be impossible of application. The magnitude of exports must depend on the size of the market, and this varies with the scope of the conflict and the preparation of the bel- 


\section{AMERICA'S CASE AGAINST GERMANY}

ligerents. As a distinguished German jurist, Professor von Bar of Göttingen, has said:

"If two states go to war with each other the world is not bound to suspend its customary pursuits in order to prevent one of the belligerents from deriving an advantage or suffering a disadvantage in consequence of such trade. To hold the contrary is to assume that belligerents, as such, have a right to dominate the rest of the world. What a belligerent has a right to expect is only that the relation between his adversary and neutral states shall remain as they were before the war; consequently the subjects of neutral states may continue to maintain commercial relations as formerly, and if they manufacture arms and ammunition, and have, before the war, sold them to everybody, they may continue to do so after the outbreak of the war, even to belligerents. ...

"It is wrong, therefore, to denounce, as has often been done, the sale of arms by neutrals to belligerents, as a business which pollutes the hands and honor of neutral countries. This phrase has no more force than a tirade launched against a fire insurance company on the ground that it is engaged in a miserable business which draws its profits from the misfortunes of others." $3 \mathrm{a}$

${ }^{s_{a}}$ See Garner, "The Sale and Exportation of Arms and Munitions of War to Belligerents," American Journal of 


\section{This and other points of the Austro-Hun-} garian memorandum were exceptionally well answered by Secretary Lansing's note sent on August 12th:

"To this assertion of an obligation to change or modify the rules of international usage on account of special conditions the Government of the United States cannot accede. The recognition of an obligation of this sort, unknown to the international practice of the past, would impose upon every neutral nation a duty to sit in judgment on the progress of a war and to restrict its commercial intercourse with a belligerent whose naval successes prevented the neutral from trade with the enemy.

"The contention of the Imperial and Royal Government appears to be that the advantages gained to a belligerent by its superiority on the sea should be equalized by the neutral powers by the establishment of a system of nonintercourse with the victor. The Imperial and Royal Government confines its comments to arms and ammunition, but, if the principle for which it contends is sound, it should apply with equal force to all articles of contraband. A belligerent controlling the high seas might possess an ample supply of arms and ammunition, but be in want of food and clothing. On the novel principle International Law, Vol. X, pp. 749, 755, and Proceedings of the American Society of International Law, Vol. X, pp. 18, 28. 


\section{AMERICA'S CASE AGAINST GERMA}

that equalization is a neutral duty, neutral nations would be obligated to place an embargo on such articles because one of the belligerents could not obtain them through commercial intercourse.

"But if this principle, so strongly urged by the Imperial and Royal Government, should be admitted to obtain by reason of the superiority of a belligerent at sea, ought it not to operate equally as to a belligerent superior on land? Applying this theory of equalization, a belligerent who lacks the necessary munitions to contend successfully on land ought to be permitted to purchase them from neutrals, while a belligerent with an abundance of war stores or with the power to produce them should be debarred from such traffic.

"Manifestly the idea of strict neutrality now advanced by the Imperial and Royal Government would involve a neutral nation in a mass of perplexities which would obscure the whole field of international obligation, produce economic confusion and deprive all commerce and industry of legitimate fields of enterprise, already heavily burdened by the unavoidable restrictions of war."

Attention was called to the fact that AustriaHungary and Germany, particularly the latter, had produced a great surplus of arms and ammunition which they sold to belligerents; and 
they had not applied the principle now advocated. The quantities were small when compared to those of the present war, but the principles involved were the same. More than this, on grounds of policy the United States must continue to assert an unrestricted right to engage in an unrestricted trade in military supplies.

"It has never been the policy of this country to maintain in time of peace a large military establishment or stores of arms and ammunition sufficient to repel invasion by a well-equipped and powerful enemy. It has desired to remain at peace with all nations and to avoid any appearance of menacing such peace by the threat of its armies and navies. In consequence of this standing policy the United States would, in the event of attack by a foreign power, be at the outset of the war seriously, if not fatally, embarrassed by the lack of arms and ammunition and by the means to produce them in sufficient quantities to supply the requirements of national defense. The United States has always depended upon the right and power to purchase arms and ammunition from neutral nations in case of foreign attack. This right, which it claims for itself, it cannot deny to others.

"A nation whose principle and policy it is to rely 


\section{AMERICA'S CASE AGAINST GERMANY}

upon international obligations and international justice to preserve its political and territorial integrity might become the prey of an aggressive nation whose policy and practice it is to increase its military strength during times of peace with the design of conquest, unless the nation attacked can, after war has been declared, go into the markets of the world and purchase the means to defend itself against the aggressor.

"The general adoption by the nations of the world of the theory that neutral powers ought to prohibit the sale of arms and ammunition to belligerents would compel every nation to have in readiness at all times sufficient munitions of war to meet any emergency which might arise and to erect and maintain establishments for the manufacture of arms and ammunition sufficient to supply the needs of its military and naval forces throughout the progress of a war. Manifestly the application of this theory would result in every nation becoming an armed camp, ready to resist aggression, and tempted to employ force in asserting its rights rather than appeal to reason and justice for the settlement of international disputes." ${ }_{4}$

Secretary Lansing's very able note covers practically all phases of the question, but attention should be directed to the fact that, for any

- The Austro-Hungarian reply made on September 24th added nothing to the discussion. 
restrictive measure to accomplish its purpose it would have to cover, to some extent at least, materials used in making munitions, for in the shipment of these we have probably done the greatest harm to Germany. Any embargo would, of course, involve the danger that we would make ourselves liable for damage done as a result of exports which had taken place in violation of law. Applied only to munitions, the measure would impose a burden that would soon prove to be intolerable; ultimate as well as primary destination would have to be inquired into unless the restriction was absolute, and even then a small army of officials would be required to make it effective. But where would the line be drawn? Would the embargo apply only to absolute contraband or to conditional as well? The practical difficulties would seem to be well nigh insurmountable. Food is even more essential to England than munitions; yet to supply this would not be deemed unneutral by any one.

It is evident, therefore, that the refusal of the United States Government to restrict the trade in munitions was abundantly justified by 


\section{AMERICA'S CASE AGAINST GERMANY}

its traditional practice; by its own interests which require that in order not to become an armed camp it be permitted, when a belligerent, to buy military stores from neutrals; by definite provisions of international law, the change of which during the progress of a war so as to deprive one group of belligerents of the advantages which they have derived through superior sea-power would be unneutral; by the difficulty of drawing any logical line, and the impossibility and danger of enforcing a restrictive measure.

A rule of international law and a very general practice sanctioned by the vast majority of authorities, must, it is submitted, have some ethical justification. That the shipments of war materials from the United States have been sufficiently large to play any decisive part in the European struggle, is, I think, extremely doubtful. But, assume that this country, through the trade of its citizens, is actually taking part in the war. Here again our legal position would be impeccable, and our moral position also, for, in the last analysis, the question would be answered by our sympathies. At the time Ger- 
many invaded Belgium, the United States entered no formal protest, but its citizens protested then, and their condemnation of Germany has ever been more bitter-augmented by the Lusitania and other outrages, the many atrocities alleged, diplomatic arrogance, and insidious propaganda. Above all considerations of the legality of restriction the United States would be unwilling, through an embargo, to assist Germany to a successful outcome of her conspiracy against the peace of the world. This, after all, is a very potent issue, and American public opinion would suffer no refusal to continue a policy that is legal, whose disregard would be unfriendly, and that, persisted in, would aid in some small measure those noble peoples (now our Allies) who were fightirg for a better civilization.

This discussion of the trade in war materials has been ventured in order to make more complete the sketch of the diplomatic exchanges between the United States and Germany during the present war. But, as I have already indicated, the munitions trade was bound up in the 


\section{AMERICA'S CASE AGAINST GERMANY}

German notes with the submarine warfare. There is no logical connection, for, while a neutral government may not itself furmish supplies to a belligerent, individuals may engage in such a trade at their own risk. That is to say, the contraband articles which are shipped, and the vessels which carry them are liable to capture and confiscation. This is the sole penalty which international law attempts to impose upon a trade in contraband. The character of a vessel's cargo does not, therefore, furnish any justification for a change in the rule. Those engaged in carrying the contraband cannot be punished; if neutrals, they cannot even be made prisoners of war. The sole penalty, to repeat, is the loss by the owners of the cargo and of the vessel. It is thus seen that it is absolutely immaterial what a particular vessel contains when it is overtaken by a submarine. The sacred immunities of the noncombatants on board are the same, and the taking of their lives cannot be justified on the ground that they are engaged in a traffic, which, however objectionable to one of the belligerents, is recognized by international law. And, in fact, while jus- 
tifying her submarine warfare on the ground that it was a reprisal for the illegal British Orders in Council, Germany has not claimed that rules of international law and considerations of humanity give her any greater license with regard to the crew or passengers on contraband-carrying boats. The justice of the trade in munitions seems, on the contrary, to have been injected into the diplomatic exchanges for the same reason that the protest against the use of the neutral flag was madeto attempt to coerce the United States into a position which would illegally operate to the detriment of the Allies, with the alternative, for refusal, of an inhuman and illegal disregard for the lives of all noncombatants-neutral as well as enemy-on the high seas. ${ }^{5}$

- Although it does not seem to have figured in the exchanges, attention may be called to the fact that the Prussian treaties (see above, p. 62) expressly justify a trade in contraband by one of the parties when the other is a belligerent. These treaties have been accepted by Germany as fully binding. 


\section{CHAPTER VII}

SUBMARINE WARFARE IN THE MEDITERRANEAN

THE German pledges which have been described came simultaneously with a marked decrease of the activity of submarines in the waters around Great Britain; and the opinion has already been ventured that perhaps so many had been destroyed that it seemed to the Imperial Government the best plan to accede to the American demands pending the completion of the many and more powerful undersea boats which were contemplated. In the Mediterranean, however, a new campaign was inaugurated, apparently participated in by both German and Austrian submarines. American interests were vitally affected when the Italian liner Ancona, bound from Naples to New York, was sunk in the Mediterranean without warning (November 7th) and more than two hundred passengers lost their lives, among them Ameri- 
can citizens. After a month's delay in order to be sure of the facts, President Wilson addressed a note--in some respects the strongest of those published-to the Austro-Hungarian Government. He said:

"The Government of the United States considers that the commander violated the principles of international law and of humanity by shelling and torpedoing the Ancona before the persons on board had been put in a place of safety or even given sufficient time to leave the vessel. The conduct of the commander can only be characterized as wanton slaughter of defenseless noncombatants, since at the time when the vessel was shelled and torpedoed she was not, it appears, resisting or attempting to escape; and no other reason is sufficient to excuse such an attack, not even the possibility of rescue."

The United States, therefore, was forced to conclude either that the commander of the submarine failed to act in accordance with his instructions or that Austria-Hungary had not issued to its under-sea boats the same orders that had been announced by Germany "in accordance with the law of nations and the principles of humanity." This latter alternative the 
United States was reluctant to believe for it would have

"to credit the Austro-Hungarian Government with an intention to permit its submarines to destroy the lives of helpless men, women, and children. It prefers to believe that the commander of the submarine committed this outrage without authority and contrary to the general or special instructions which he had received.

"As the good relations of the two countries must rest upon a common regard for law and humanity, the Government of the United States cannot be expected to do otherwise than to demand that the Imperial and Royal Government denounce the sinking of the $A n$ cona as an illegal and indefensible act; that the offcer who perpetrated the deed be punished; and that reparation by the payment of an indemnity be made for the citizens of the United States who were killed or injured by the attack on the vessel.

"The Government of the United States expects that the Austro-Hungarian Government, appreciating the gravity of the case, will accede to its demand promptly; and it rests this expectation on the belief that the Austro-Hungarian Government will not sanction or defend an act which is condemned by the world as inhumane and barbarous, which is abhorrent to all civilized nations, and which has caused the death of innocent American citizens." 
These were strong words and indicated that the United States was tired of temporizing; that the submarines must conduct their operations so as to safeguard the lives of noncombatants, with the alternative of having diplomatic relations severed.

Austria's reply, made on December 15th, was a very evasive and in some respects impertinent document. It said that the "sharpness with which the Government of the United States considers it necessary to blame the commanding officer of the submarine" was not justified by any specification of the exact circumstances of the sinking; that the number, names. and fate of the American citizens on board were not enumerated; that no juridical reasons for the demands were given but in lieu thereof the correspondence with Germany was referred to, and Austria-Hungary had no authentic knowledge of all the pertinent communications; and that the Dual Monarchy "must, in order to preclude possible misunderstandings, declare that as a matter of course it reserves to itself full freedom of maintaining its own legal views in the discussion of the case of the Ancona." Aus- 


\section{AMERICA'S CASE AGAINST GERMANY}

tria-Hungary, the note concluded, "in no less degree than the American Government and under all circumstances sincerely deplores the fate of the innocent victims of the incident in question."

The American demands were repeated immediately. They quoted the Austro-Hungarian Chargé d'Affaires at Washington as communicating to the Department of State subsequent to the sinking, an admiralty report in which it was admitted that the vessel had been sunk while her engines were stopped and passengers were still on board.

"This admission alone is, in the view of the Government of the United States, sufficient to fix upon the commander of the submarine which fired the torpedo the responsibility for having willfully violated the recognized law of nations and entirely disregarded those humane principles which every belligerent should observe in the conduct of war at sea. In view of these admitted circumstances the Government of the United States feels justified in holding that the details of the sinking of the Ancona, the weight and character of the additional testimony corroborating the Admiralty's report, and the number of Americans killed or injured are in no way essential mat- 
ters of discussion. The culpability of the commander is in any case established, and the undisputed fact is that citizens of the United States were killed, injured, or put in jeopardy by his lawless act.

"The rules of international law and the principles of humanity which were thus willfully violated by the commander of the submarine have been so long and so universally recognized and are so manifest from the standpoint of right and justice that the Government of the United States does not feel called upon to debate them and does not understand that the Imperial and Royal Government questions or disputes them."

To the United States, therefore, the only course open was to hold the Imperial and Royal Government responsible for the act of its commander and to renew the demands of the previous communication. The seriousness of the incident and the necessity for compliance were again intimated in the concluding warning that the United States "sincerely hopes that the foregoing statement of its position will enable the Imperial and Royal Government to perceive the justice of those demands and to comply with them in the same spirit of frankness and with the same concern for the good relations now 


\section{AMERICA'S CASE AGAINST GERMANY}

existing between the United States and AustriaHungary which prompted the Government of the United States to make them."

In response to this (December 29th), AustriaHungary expressed itself in thorough agreement with the Washington cabinet "that even in war the sacred demands of humanity must be complied with." And agreement was expressed also with the principle "that hostile private ships, in so far as they do not flee or offer resistance, may not be destroyed without the persons on board having been placed in safety." This was an important admission and conceded practically everything that the United States was contending for. The note then went on to outline the evidence secured by an investigation and to discuss the circumstances of attack-in contradiction of the American view as to the damage done after the Ancona had stopped-and the responsibility for the loss of life. While the vessel was torpedoed after it had ceased the attempt to get away, the Imperial and Royal Government asserted that inexpert launching of the lifeboats and failure of 
the crew to put the passengers in a place of safety were responsible.

The officer in command of the submarine had been "punished in accordance with the rules in force in this matter for exceeding his instructions," and while the case of the Ancona could be regarded as having been cleared up, the Imperial and Royal Government reserved "to itself for a future time the discussion of the difficult questions of international law in connection with submarine warfare." 1

${ }^{1}$ In respect to the indemnity to American citizens, the following observations were offered: "As a matter of course the investigation into the sinking of the Ancona could not establish to what degree American citizens are entitled to a claim for indemnity. Even according to the view of the Washington Cabinet, the Imperial and Royal Government can not be held answerable for the injuries which were caused by the undoubtedly justified firing upon the fleeing ship. Just as little might it have to answer for the injuries which occurred before the torpedoing due to the faulty rigging out of the boats or to the eapsizing of the boats which had been lowered.

"The Imperial and Royal Government must assume that the Washington Cabinet is able and willing to furnish it with the information which is required in this respect and which is certainly not immaterial. However, should the more precise circumstances under which the American citizens were injured be unknown to the Government of the United States due to a lack of the proper material evidence, the Government of the Imperial and Royal Government in consideration of the humanely deeply deplorable incident, and guided by the desire 


\section{AMERICA'S CASE AGAINST GERMANY}

This reply was encouraging, but the satisfaction was short-lived ${ }^{2}$ for almost immediately word was received of the sinking of the Peninsular \& Oriental liner Persia off the coast of Crete on December 30th. More than two hundred noncombatants lost their lives, among them an American consul. Secretary Lansing at once instructed the American ambassadors at Berlin and Vienna to make informal inquiries looking to the nationality of the submarine responsible. The facts are not yet clear

of again manifesting to the Government of the United States its friendly sentiments, would be readily willing to overlook this gap in the evidence and to extend the indemnity also to those injuries the direct cause of which could not be ascertained."

${ }^{2}$ On December 5, 1915, the American ship Petrolite had been shelled by a submarine and compelled to furnish it supplies. The commander of the submarine explained the firing on the ground that he thought that the American flag was a ruse de guerre and that the vessel was attempting to ram him. Negotiations dragged and on July 21, 1916, in the last published communication to Austria-Hungary, Secretary of State Lansing denounced "the conduct of the commander of the submarine in attacking the Petrolite and in coercing the captain as a deliberate insult to the flag of the United States and an invasion of the rights of American citizens for which this Government requests that an apology be made; that the commander of the submarine be punished; and that reparation be made for the injuries sustained by the payment of a suitable indemnity." 
as Germany, Austria-Hungary, and Turkey have all denied that one of their submarines sank the vessel, but it is certain that the forceful language of the United States had but slight effect since two other passenger steamers were sunk without warning in the Mediterraneanthe Japanese liner Yasaka Maru on December 21st and the French liner Ville de la Ciotat on December 24th.

But Ambassador Bernstorff again came to the fore on January 7 th with renewed pledges:

"1. German submarines in the Mediterranean had, from the beginning, orders to conduct cruiser warfare against enemy merchant vessels only in accordance with general principles of international law, and in particular measures of reprisal, as applied in the war zone around the British Isles, were to be excluded.

" 2. German submarines are therefore permitted to destroy enemy merchant vessels in the Miediterranean -i. e., passenger as well as freight ships as far as they do not try to escape or offer resistance-only after passengers and crews have been accorded safety.

"3. All cases of destruction of enemy merchant ships in the Mediterranean in which German submarines are concerned are made the subject of official investigation and, besides, submitted to regular prize 


\section{AMERICA'S CASE AGAINST GERMANY}

court proceedings. In so far as American interests are concerned, the German Government will communicate the result to the American Government. Thus also in the Persia case if the circumstances should call for it.

"4. If commanders of German submarines should not have obeyed the orders given to them, they will be punished; furthermore, the German Government will make reparation for damage caused by death of or injuries to American citizens." 3

These pledges were of course tantamount to further admissions that the submarine campaign was illegal ; but Count Bernstorff's promise in settlement of the Arabic incident was, in the immunity given "liners," not limited to locality and read in connection with the assertions of the German note of May 4th, replying to our ultimatum in the Sussex case, cast doubt on the bona fides of all the pledges. In this communication-which will be treated more in detail later-Germany said that no assurances had been given the United States concerning the warfare against enemy trade in enemy ves-

${ }^{8}$ At the time these pledges were made, Secretary Lansing published the note of November 29, 1915 concerning the Frye case and defining the measure of safety to be accorded those on vessels that were to be sunk. See above, p. 106. 
sels-yet the note of September 1st in promising that "liners" would not be sunk without warning surely was calculated to convey a contrary impression to the American people. But before this open avowal of May 4th, the locality mentioned in this pledge of January 7 th was sufficient to cause many doubts to be cast upon the sincerity of the German undertakings.

Nevertheless, the "conversations" between Secretary Lansing and Count Bernstorff over the Lusitania continued, and there were prolonged negotiations during which, it was reported, diplomatic relations were several times on the point of being broken off because Germany refused to admit that her act was unjustifiable. The exact terms of the settlement have not been made public, but their general nature has been the subject of apparently inspired newspaper reports. Germany, in view of the fact that, contrary to her own interpretation of international law, the United States did not consider reprisals legal, admitted that the attack on the Lusitania was unjustifiable so far as it involved the lives of neutrals, agreed to pay an indemnity for the American lives lost "as an 
act of liability,' and promised that the outrage would not be repeated. ${ }^{4}$

But on February 8th, while the negotiations neared a conclusion, Germany announced a new policy toward armed merchantmen which wiped out her repeated pledges, vitiated the Lusitania agreement, and reopened the whole submarine controversy. For the attitude of the United States was that in sinking the Lusitania Germany had committed a hostile act which would have to be disavowed with offers of reparation in order that diplomatic relations might continue between the two powers, and pending any attitude on Germany's part other than an intention to abide by her pledges, the settlement would not be proceeded with.

Before considering the question of armed merchantmen, which in some respects raises more difficult points of international law than any other phase of the controversy, it may be well to enumerate briefly once more just what concessions the United States had thus far se-

"The last point of difference was as to whether Germany would "assume" or "admit" liability and the latter word was assented to by Berlin on February 15th. 
cured. Austria-Hungary had in general agreed to abide by existing international rules-although contrary to the demands of the first Lusitania note submarines could be used against merchant ships if the safety of those on board was assured-and this pledge was joined in by Germany so far as the Mediterranean operations were concerned. ${ }^{5}$ In the socalled war zone around the British Isles the pledges were limited only to "liners" that did not attempt to escape, and while the right of American vessels to traverse this war zone was apparently admitted, Germany did not consider "unfortunate accidents" in sinking them illegal but simply as imposing liability on her under

s One other incident caused further exchanges between the United States and Austria-Hungary. On April 11, 1916, the Russian bark Imperator was destroyed by an Austrian submarine in the Mediterranean and an American citizen was wounded. It was explained that after the vessel had been warned by a shot across her bows, no disposition was shown on the part of the crew to abandon her. A second shot was fired through the rigging. The crew then embarked in boats, and of two sailors who had been wounded, neither was an American citizen. According to the ship's papers there was only one American eitizen on board, and if, "to the regret of the Austro-Hungarian authorities,' he was wounded, the explanation was that " the bark failed to comply with the submarine's challenge to stop when ordered.", 


\section{AMERICA'S CASE AGAINST GERMANY}

the old Prussian treaties. Finally, the measure of safety to be accorded was but poorly defined. Nevertheless, while relinquishing the international spirit of the first Lusitania note that submarines were not adapted for cruiser warfare on commerce, the United States had conceded none of its neutral rights. But all these questions were again opened, with the position of the United States more assailable, by the announcement that after March 1st all armed private ships would be sunk without warning. 


\section{CHAPTER VIII}

ARMED MERCHANTMEN

$\mathrm{A}_{\mathrm{T}}$ the outbreak of the war the American Department of State had very definitely passed upon the question of armed merchantmen. The British Embassy at Washington informed the Secretary of State that a certain number of merchantmen had been armed, but solely for defense, and that since the British naval regulations did not permit the conversion of merchantmen into warships on the high seas or in neutral ports, these armed merchantmen did not have even a potential combatant status. These communications were merely acknowledged, but on September 19, 1914, the Department of State issued a comprehensive memorandum defining the status of merchant ships carrying guns.

The memorandum stated that a merchant vessel of belligerent nationality might carry an 


\section{AMERICA'S CASE AGAINST GERMANY}

armament for the sole purpose of defense without acquiring the character of a ship of war, but that the presence on board of an armament created a presumption that it was for offensive purposes. This might be rebutted by suitable proof that the number of guns was small and that their caliber did not exceed six inches; that they were not mounted on the forward part of the vessel; that the quantity of ammunition was small; that the ship carried only its usual crew; that the purpose to engage in trade, as before the outbreak of war, was clearly evident, only sufficient fuel for this purpose being carried; that the cargo was not suited for a vessel engaging in hostile operations; that passengers were carried, and that the speed of the ship was slow.

Against this ruling Germany protested on the ground that it failed "to comply with the principles of neutrality. This equipment of British merchant vessels with artillery is for the purpose of making armed resistance against German cruisers. Resistance of this sort is contrary to international law, because, in a military sense, a merchant vessel is not permitted to de- 
fend itself against a war vessel." This protest was received on October 15th and the reply of the United States was made on November 7th. It said that "the practice of a majority of nations and the consensus of opinion by the leading authorities on international law, including many German writers, support the proposition that merchant vessels may arm for defense without losing their private character, and that they may employ such armament against hostile attack without contravening the principles of international law."

Now, this was a vigorous and exact statement of the accepted international law of the question. Chief Justice Marshall in the famous case of the Nereide had decided that a belligerent vessel had a perfect right to arm in selfdefense and that a neutral had a right to transport his goods in such an armed vessel. The armed vessel in this case "had a right to defend herself, did defend herself, and might have captured an assailing vessel; but to search for the enemy would have been a violation of her charter party and of her duty."

The practice of arming ships in self-defense 


\section{AMERICA'S CASE AGAINST GERMANY}

is a very old one, and dates from the time when the seas were infested by pirates. With the disappearance of pirates and the abolition by the Declaration of Paris (1856) of privateering, the necessity of ships arming to defend themselves was diminished, because against a modern cruiser a defensively armed merchantman would be almost impotent. But at the Second Hague Peace Conference a convention was adopted providing for the conversion of merchant vessels into war ships and against these a defensively armed merchant vessel would have the same chance of escape that it formerly had against a privateer or a pirate. A reason for the armament therefore came into existence at the Second Hague Peace Conference, and in March, 1913, it was announced that British merchant vessels were to be defensively armed. That this was perfectly legal was recognized, as I have said, by established practice, the United States Supreme Court, a Hague Convention, and the publicists of Great Britain, the United States, France, Italy, Belgium, and Holland. The consensus of international opinion was in its favor, as correctly stated by the 
memorandum of the United States in reply to the German protest.

Furthermore, in 1913, the Institute of International Law at its Oxford meeting in Article 12 of the "Manuel des Lois de la Guerre Maritime" said that the use of force against the attack of a naval enemy was permissible. This view was combated by one of the German representatives but was adopted by a large majority. Some German opinion, however, has been opposed to the rule, but as a leading authority on the subject points out:

"The right of a merchant ship to defend herself, and to be armed for that purpose, has not, so far as I am aware, been doubted for two centuries, until the question has again become one of practical importance. The historical evidence of the practice down to the year 1815 is overwhelming. Dr. Schramm [a German writer], in his elaborate denial of the right, fails to distinguish between the position in which a belligerent warship stands to an enemy merchant ship, and that in which it stands to a neutral merchant ship. This failure is important, and goes to the root of the matter, for whereas the visit of a belligerent warship to an enemy merchant ship is, under existing law, merely the first step to capture and is itself a hostile act, and is undertaken solely 


\section{AMERICA'S CASE AGAINST GERMANY}

in order to enable the captor to ascertain that the ship is one which is not exempt by custom, treaty or convention from capture; the visit to a neutral ship, though justified by the fact of the existence of war, is not a hostile act. By long custom a belligerent warship has a right of visit and search of all neutral merchant vessels, and this right is exercised in order to ascertain whether a vessel is in fact neutral, and not engaged in any acts such as attempting to break blockade, the carriage of contraband or the performance of any unneutral service which would justify its detention and condemnation. 'It has been truly denominated a right growing out of, and ancillary to the greater right of capture. Where this greater right may be legally exercised without search [as in the case of enemy ships] the right of search can never arise or come into question.' A belligerent warship has a right to capture an enemy merchant ship, and the latter is under no duty to submit; it has a corresponding right to resist capture, which is an act of violence and hostility. By resisting, the belligerent violates no duty, he is held by force and may escape if he can. But forcible resistance, as distinct from flight, on the part of a neutral merchant ship is universally admitted as a just ground for the condemnation of the ship.", 1

${ }^{1}$ Higgins, "Armed Merchant Ships," American Journal of International Law, Vol. 8, p. 705. The quotation is from Chief Justice Marshall in the Nereide, 9 Cranch, 338 (1815). 
In addition, the crews of vessels which resist capture become prisoners of war; the resisting vessel, according to the Anglo-American doctrine, can make a lawful prize of the vessel which attacks it. "The crew of a merchant ship is a body of men acting together in defense of their ship and their liberty, a body of individuals who by the customary law of nations have received combatant privileges when resisting capture by an enemy warship. They offer a striking analogy to the spontaneous rising of the inhabitants of an occupied territory, who have now received by convention the right which merchant sailors have had for centuries." 2

Now the mere fact that a merchant vessel may resist capture, does not, of course, permit the capturing vessel to sink it without warning. The provisions of international law are definite on this point. If resistance takes place, sufficient force can be used to overcome this resistance, but to the merchant vessel is given the option of deciding whether it will submit at

'Higgins, op. cit., and Hague Convention (IV, 1907) Respecting the Laws and Customs of War on Land. 


\section{AMERICA'S CASE AGAINST GERMANY}

once, attempt to flee, or resist, and the vessel desiring to make the capture must await the exercise of this option before it uses force. Passengers on a defensively armed merchant vessel are protected until the resistance takes place; then the responsibility is on the captain of the merchant vessel if the exercise of force by the capturing vessel, conceding that this force is no more than is necessary to overcome the resistance, causes injury to the passengers. And the mere fact that a submarine may be sunk by one shot does not furnish any basis for a change in the rule. It is one of the hazards of submarine activity against commerce that resistance may be immediately and completely effective.

With Mr. Lansing's reply of November 7, 1914, the question of armed merchantman rested for some time. In the communications over the war zone and the Lusitania, Germany claimed that armed merchantmen could not be considered undefended territory, and that she was, therefore, justified in sinking them without warning. One of her excuses for sinking the Lusitania was that the ship carried an 
armament, but in its replies, the United States did not attempt to controvert this view of the obligations on the submarine, but contented itself with pointing out that the Lusitania was in fact unarmed.

In the early part of 1916, however, the whole question was raised again. Italian and British ships were armed on account of the ruthless submarine campaign which was being waged in the Mediterranean. The hint was given that Germany intended to sink all armed merchantmen without warning, and so on January 18, 1916, Secretary of State Lansing issued a truly remarkable document which was designed to obviate this threat to the lives and interests of American citizens on board of vessels which might carry an armament. He proposed that the practice of arming merchant vessels be abolished, and while he had himself signed the note of November 7th which upheld the right of a merchantman to resist capture, he now declared that "an enemy merchant vessel when ordered to do so by a belligerent submarine should immediately stop." The memorandum concluded with this statement: 


\section{AMERICA'S CASE AGAINST GERMANY}

"I should add that my Government is impressed with the reasonableness of the argument that a merchant vessel carrying armament of any sort, in view of the character of the submarine warfare and the defensive weakness of underseas craft, should be held to be an auxiliary cruiser and so treated by a neutral as well as by a belligerent Government, and is seriJusly considering instructing its officials accordingly."

Now, this proposal was of course unanimously declined by the Entente Allies. Figures announced much later by the British Admiralty showed that more than seventy-five per cent. of all armed vessels escaped destruction by submarines, while of the unarmed ones only twentyfour per cent. escaped when attacked. The acceptance of Mr. Lansing's suggestion would have meant that the Entente Powers voluntarily permit a much larger proportion of their shipping to be sunk, with the saving of more lives perhaps, but with license on the part of Germany to plead in any case that destruction without warning was justified because of the presence of a gun or a threatened attack. The effectiveness of submarines against commerce -a use which had been objected to by the 
United States in its early Lusitania exchanges -would be immeasurably increased.

Germany, however, took advantage of the proposals thus made by Secretary Lansing, and on February 11, 1916, announced that after March 1st all armed merchantmen would be sunk without warning. The diplomatic position of the United States had been weakened and discussion of the matter began in Congress where a resolution was introduced warning Americans to keep off armed merchant ships of belligerent nationality. With apparently a majority in each House favoring its passage, the Administration interfered. Secretary Lansing's note had been merely a proposal for a modus vivendi like the suggestions made to England and Germany in the early days of the war zone; when rejected by one group of belligerents, it could not be put into operation by the other group nor could any advantage be derived from its having been made. President Wilson wrote (February 24th) Senator Stone that the duty of the country was clear:

"No nation, no group of nations, has the right while war is in progress to alter or disregard the 


\section{AMERICA'S CASE AGAINST GERMANY}

principles which all nations have agreed upon in mitigation of the horrors and sufferings of war, and if the clear rights of American citizens should ever unhappily be abridged or denied by any such action we should, it seems to me, have in honor no choice as to what our own course should be.

"For my own part, I cannot consent to any abridgement of the rights of American citizens in any respect. The honor and self-respect of the nation are involved. We covet peace and shall preserve it at any cost but the loss of honor. To forbid our people to exercise their rights for fear we might be called upon to vindicate them would be a deep humiliation indeed. It would be an implicit, all but an explicit, acquiescence in the violation of the rights of mankind everywhere and of whatever nation or allegiance. It would be a deliberate abdication of our hitherto proud position as spokesmen, even amidst the turmoil of war, for the law and the right. It would make everything this Government has attempted and everything that it has achieved during this terrible struggle of nations meaningless and futile.

"It is important to reflect that if in this instance we allowed expediency to take the place of principle, the door would inevitably be opened to still further concessions. Once accept a single abatement of right and many other humiliations would certainly follow, and the whole fine fabric of international law might 
crumble under our hands piece by piece. What we are contending for in this matter is of the very essence of the things that have made America a sovereign nation. She cannot yield them without conceding her own impotency as a nation and making virtual surrender of her independent position among the nations of the world."

This letter had its effect and the resolution was tabled.

Meanwhile there was much uncertainty, as the position of the Administration was not definitely announced until April 26th, when there was published a memorandum dated March 25th which set forth in a comprehensive fashion the views of the United States as to armed merchantmen. Following are the pertinent paragraphs with reference to the duties of a belligerent cruiser or submarine upon overtaking a defensively armed vessel:

“(7) When a belligerent warship meets a merchantman on the high seas, which is known to be enemy owned, and attempts to capture the vessel, the latter may exercise its right of self-protection either by flight or by resistance. The right to capture and the right to prevent capture are recognized as equally justifiable. 


\section{AMERICA'S CASE AGAINST GERMANY}

"(8) The exercise of the right of capture is limited, nevertheless, by certain accepted rules of conduct based on the principles of humanity and regard for innocent property, even if there is definite knowledge that some of the property, cargo, as well as the vessel, is of enemy character. As a consequence of these limitations, it has become the established practice for warships to give merchant vessels an opportunity to surrender or submit to visit and search before attempting to seize them by force. The observance of this rule of naval warfare tends to prevent the loss of life of noncombatants and the destruction of innocent neutral property, which would result from sudden attack.

"(9) If, however, before a summons to surrender is given, a merchantman of belligerent nationality, aware of the approach of an enemy warship, uses its armament to keep the enemy at a distance, or after it has been summoned to surrender it resists or flees, the warship may properly exercise force to compel surrender.

"(10) If the merchantman finally surrenders, the belligerent warship may release it or take it into custody. In the case of an enemy merchantman it may be sunk, but only if it is impossible to take it into port, and provided always that the persons on board are put in a place of safety. In the case of neutral merchantman, the right to sink it in any circumstance is doubtful. 
"(11) A merchantman entitled to exercise the right of self-protection may do so when certain of attack by an enemy warship, otherwise the exercise of the right would be so restricted as to render it ineffectual. There is a distinct difference, however, between the exercise of the right of self-protection and the act of cruising the seas in an armed vessel for the purpose of attacking enemy naval vessels.

"(12) In the event that merchant ships of belligerent nationality are armed and under commission or orders to attack in all circumstances certain classes of enemy naval vessels for the purpose of destroying them, and are entitled to receive prize money for such service from their Government, or are liable to a penalty for failure to obey the orders given, such merchant ships lose their status as peaceable merchant ships and are to a limited extent incorporated in the naval forces of their Government, even though it is not their sole occupation to conduct hostile operations.

"(13) A vessel engaged intermittently in commerce and under a commission or orders of its Government imposing a penalty, in pursuing and attacking enemy naval craft, possesses a status tainted with a hostile purpose which it can not throw aside or assume at will. It should, therefore, be considered as an armed public vessel and receive the treatment of a warship by an enemy and by neutrals. Any person taking passage on such a vessel can not expect immunity 


\section{AMERICA'S CASE AGAINST GERMANY}

other than that accorded persons who are on board a warship. A private vessel, engaged in seeking enemy naval craft, without such a commission or orders from its Government, stands in a relation to the enemy similar to that of a civilian who fires upon the organized military forces of a belligerent, and is entitled to no more considerable treatment."

These are so clear that further comment of mine is useless, and in concluding this brief treatment of the attitude of the United States on the subject of armed merchantmen, only one consideration need be stressed. Nothing has been said here about the German claim that British merchant vessels were armed for offense against submarines. If true, the situation would be altered, but in no case has Germany been able to relieve herself of liability to the United States on the basis of her plea that a defensively armed vessel is not undefended territory. She has, to be sure, claimed, as she did in the Lusitania case, that the ship sunk carried a gun, but the United States has had no difficulty in traversing these contentions. The German decree of January 31, 1917, furthermore, does not confine the operations of submarines 
to armed vessels and thus America's case against Germany is firmly established without the necessity of rebutting the German plea that an armed vessel can be sunk without warning. 


\section{CHAPTER IX}

THE "SUSSEX" AND THE PLEDGES CONDITIONALLY RENEWED

German submarine activities against shipping began on March 1st, the day the new campaign was to go into effect, but the sinkings were indiscriminate and were not confined to merchantmen that carried armament. Thus the status of armed merchant vessels was not introduced to embarrass the United States or to excuse Germany. The unarmed French liner Patria from Naples to New York was attacked by a submarine north of Tunis but was able to escape. The Norwegian bark Silius while lying at anchor in Havre Roads was torpedoed without warning on March 9th and of the seven Americans in the crew, one was injured. Of three Americans on board the Dutch liner Tubantia in the North Sea all were saved, but during this same period Ambassador Gerard 
was requested to obtain prompt reports from the Imperial German Government as to their responsibility for the sinking of the Englishman, the Manchester Engineer, the Eagle Point, and the Berwindale, all of which had Americans on board. But the crowning outrage came on March 24th when the channel steamer Sussex, an unarmed passenger boat, was sunk without warning. Several Americans were among the passengers who were killed or injured.

The reply to Mr. Gerard's inquiry as to whether German submarines were responsible - that they were was indisputable from the fact that in several instances periscopes or the underseas boats themselves had been visiblewas dated April 10th. It first considered the four minor cases concerning which inquiry had been made. The Berwindale, the Englishman, and the Eagle Point had all tried to escape and had been shelled in order to compel surrender. Time was afforded for the crews to leave before the sinkings were effected. In the case of the Manchester Engineer, the investigation had not been concluded. As for the Sussex, Germany attempted to make the extraordinary plea 


\section{AMERICA'S CASE AGAINST GERMANY}

that her submarines had not been responsible for this outrage.

In the locality in which the Sussex sank, it was explained, a German submarine commander encountered what seemed to him to be a war vessel. "He was led to this conviction, one, by the flush of the vessel; two, by the warship form of stern, protruding diagonally backward and then falling downward; three, by the warshiplike coat of paint; four, by the high speed of about eighteen sea miles developed by the vessel; five, by the circumstances that the vessel did not follow" the naval course for merchant shipping, "but sailed in the middle of the channel, pointing about for Havre." The vessel was torpedoed and a severe explosion tore loose the whole foreship up to the bridge. This warranted "the safe conclusion that there were large quantities of ammunition on board." To the note were attached sketches made by the submarine commander of the vessel he sank at this time, and a sketch of the Sussex taken from the London Daily Graphic. A comparison of the pictures would show that the two vessels were not identical. Under these circumstances, 
"the German Government is forced to assume that the damaging of the Sussex is to be attributed to another cause than the attack of a German submarine." It was suggested that an English mine might have been responsible, since, it was claimed, twenty-six of them were exploded by German naval forces in the Channel on April 1st and 2nd. Finally, Germany declared "its readiness to permit the facts to be ascertained by a mixed commission of investigation, pursuant to" the Hague Convention for the Pacific Settlement of International Disputes.

President Wilson's reply, on April 18th, was the sharpest yet sent to Germany, and the threat that diplomatic relations would be severed, coupled with his appearance before Congress, so convinced Germany of the seriousness of his purpose that she pledged herself not to sink vessels within or without the war zone "without warning and without saving human lives unless the ship attempts to escape or offer resistance." The note (the address to Congress was largely in the same language) with elaborate appendices giving the evidence avail- 
174 AMERICA'S CASE AGAINST GERMANY

able, showed it to be indisputable that a submarine had sunk the Sussex. If it had been an isolated case, "the Government of the United States might find it possible to hope that the officer who was responsible for that act had willfully violated his orders or had been criminally negligent in taking none of the precautions they prescribed, and that the ends of justice might be satisfied by imposing upon him an adequate punishment, coupled with a formal disavowal of the act and payment of a suitable indemnity by the Imperial Government. But, though the attack upon the Sussex was manifestly indefensible and caused a loss of life so tragical as to make it stand forth as one of the most terrible examples of the inhumanity of submarine warfare as the commanders of German vessels are conducting it, it unhappily does not stand alone.

"On the contrary, the Government of the United States is forced by recent events to conclude that it is only one instance, even though one of the most extreme and most distressing instances, of the deliberate method and spirit of indiscriminate destruction of merchant ves- 
sels of all sorts, nationalities, and destinations which have become more and more unmistakable as the activity of German undersea vessels. of war has in recent months been quickened and extended."

The President then reviewed his course since Germany announced her intention in February, 1915. The United States had taken the position that such a measure "could not be pursued without constant gross and palpable violations of the accepted law of nations"' which was "not of recent origin or founded upon merely arbitrary principles set up by convention," but was "'based, on the contrary, upon manifest principles of humanity and has long been established with the approval and by the express assent of all civilized nations." The Imperial Government declined to abandon this policy and promised that the danger to neutrals would be reduced to a minimum by the instructions issued submarine commanders, but this result did not take place.

"Again and again the Imperial Government has given its solemn assurances to the Government of the United States that at least passenger ships would 


\section{AMERICA'S CASE AGAINST GERMANY}

not be thus dealt with, and yet it has repeatedly permitted its undersea commanders to disregard those assurances with entire impunity. As recently as February last it gave notice that it would regard all armed merchantmen owned by its enemies as part of the armed naval forces of its adversaries and deal with them as with men-of-war, thus, at least by implication, pledging itself to give warning to vessels which were not armed and to accord security of life to their passengers and crews; but even this limitation their submarine commanders have recklessly ignored.

"Vessels of neutral ownership, even vessels of neutral ownership bound from neutral port to neutral port, have been destroyed, along with vessels of belligerent ownership, in constantly increasing numbers. Sometimes the merchantmen attacked have been warned and summoned to surrender before being fired on or torpedoed; sometimes their passengers and crews have been vouchsafed the poor security of being allowed to take the ship's boats before the ship was sent to the bottom. But again and again no warning has been given, no escape even to the ship's boats allowed to those on board. Great liners like the Lusitania and Arabic, and mere passenger boats like the Sussex, have been attacked without a moment's warning, often before they have even become aware that they were in the presence of an armed ship of the enemy, and the lives of noncombatants, passengers, 
and crew, have been destroyed wholesale and in a manner which the Government of the United States cannot but regard as wanton and without the slightest color of justification. No limit of any kind has, in fact, been set to their indiscriminate pursuit and destruction of merchantmen of all kinds and nationalities within the waters which the Imperial Government has chosen to designate as lying within the seat of war. The roll of Americans who have lost their lives upon ships thus attacked and destroyed has grown month by month until the ominous toll has mounted into the hundreds. ${ }^{1}$

"The Government of the United States has been

${ }^{1}$ In his address to Congress President Wilson referred particularly to the Sussex as follows:

"One of the latest and most shocking instances of this method of warfare was that of the destruction of the French cross-channel steamer Sussex. It must stand forth, as the sinking of the steamer Lusitania did, as so singularly tragical and unjustifiable as to constitute a truly terrible example of the inhumanity of submarine warfare as the commanders of German vessels have for the past 12 months been conducting it. If this instance stood alone, some explanation, some disavowal by the German Government, some evidence of criminal mistake or willful disobedience on the part of the commander of the vessel that fired the torpedo, might be sought or entertained, but unhappily it does not stand alone. Recent events make the conclusion inevitable that it is only one instance, even though it be one of the most extreme and distressing instances, of the spirit and method of warfare which the Imperial German Government has mistakenly adopted and which from the first exposed that Government to the reproach of thrusting all neutral rights aside in pursuit of its immediate objects." 


\section{AMERICA'S CASE AGAINST GERMANY}

very patient. At every stage of this distressing experience of tragedy after tragedy it has sought to be governed by the most thoughtful consideration of the extraordinary circumstances of an unprecedented war and to be guided by sentiments of very genuine friendship for the people and Government of Germany. It has accepted the successive explanations and assurances of the Imperial Government as, of course, given in entire sincerity and good faith, and has hoped, even against hope, that it would prove to be possible for the Imperial Government so to order and control the acts of its naval commanders as to square its policy with the recognized principles of humanity as embodied in the law of nations. It has made every allowance for unprecedented conditions and has been willing to wait until the facts became unmistakable and were susceptible of only one interpretation.

"It now owes it to a just regard for its own rights to say to the Imperial Government that that time has come. It has become painfully evident to it that the position which it took at the very outset is inevitable, namely, the use of submarines for the destruction of an enemy's commerce, is, of necessity, because of the very character of the vessels employed and the very methods of attack which their employment of course involves, utterly incompatible with the principles of humanity, the long-established and incontrovertible 
rights of neutrals, and the sacred immunities of noncombatants.

"If it is still the purpose of the Imperial Government to prosecute relentless and indiscriminate warfare against vessels of commerce by the use of submarines, without regard to what the Government of the United States must consider the sacred and indisputable rules of international law and the universally recognized dictates of humanity, the Government of the United States is at last forced to the conclusion that there is but one course it can pursue: Unless the Imperial Government should now immediately declare and effect an abandonment of its present methods of submarine warfare against passenger and freight-carrying vessels, the Government of the United States can have no choice but to sever diplomatic relations with the German Empire altogether. This action the Government of the United States contemplates with the greatest reluctance, but feels constrained to take in behalf of humanity and the rights of neutral nations.", 2

${ }^{2}$ The concluding paragraphs of the President's address to Congress were as follows:

"I have deemed it my duty, therefore, to say to the Imperial German Government that if it is still its purpose to prosecute relentless and indiscriminate warfare against vessels of com. merce by the use of submarines, notwithstanding the now demonstrated impossibility of conducting that warfare in accordance with what the Government of the United States must consider the sacred and indisputable rules of international law and the universally recognized dictates of humanity, the Government 


\section{AMERICA'S CASE AGAINST GERMANY}

Here, it should be noticed, President Wilson reverted to the position of his first Lusitania note that submarines could not be used against commerce without a disregard of the sacred immunities of noncombatants, and, more than that, he asserted the inevitability of a break with Germany, not simply on account of the

of the United States is at last forced to the conclusion that there is but one course it can pursue, and that unless the $1 \mathrm{~m}$ perial German Government should now immediately declare and effect an abandonment of its present methods of warfare against passenger and freight carrying vessels this Government can have no choice but to sever diplomatic relations with the Government of the German Empire altogether.

"This decision I have arrived at with the keenest regret; the possibility of the action contemplated I am sure all thoughtful Americans will look forward to with unaffected reluctance. But we can not forget that we are in some sort and by the force of circumstances the responsible spokesmen of the rights of humanity, and that we can not remain silent while those rights seem in process of being swept utterly away in the maelstrom of this terrible war. We owe it to a due regard for our own rights as a Nation, to our sense of duty as a representative of the rights of neutrals the world over, and to a just conception of the rights of mankind to take this stand now with the utmost solemnity and firmness.

"I have taken it, and taken it in the confidence that it will meet with your approval and support. All sober-minded men must unite in hoping that the Imperial German Government, which has in other circumstances stood as the champion of all that we are now contending for in the interest of humanity, may recognize the justice of our demands and meet them in the spirit in which they are made." 
loss of American citizens but because the methods of attack were "incompatible with the principles of humanity" and the rights of neutrals. But the objection to the use of submarines at all is apart from the main contention that the passengers and crew must be saved before a vessel may be sunk and Germany's agreement satisfied the demands of the United States.

The German reply, delivered on May 4th, admitted the possibility that the ship torpedoed was the Sussex but repudiated the assertion of the United States that the incident was "but one instance of a deliberate method of indiscriminate destruction of vessels of all sorts, nationalities, and destinations by German submarine commanders." Since the United States had omitted to refer to concrete facts, it was of little avail to enter upon details. Germany, the note claimed, "had imposed far-reaching" restraints upon the use of the submarine weapon, solely in consideration of neutrals' interests, in spite of the fact that these restrictions are necessarily of advantage to Germany's enemies. No such consideration has ever been shown neutrals by Great Britain and her 
Allies." German submarine commanders have had orders to act in accordance with the principles of visit and search, the sole exception being warfare against enemy trade carried on in enemy vessels in the war zone. No assurances as to this have ever been given the United States. These orders are executed in good faith but errors can not be prevented; and even in cases where only cruiser warfare is resorted to, neutral persons and property come to grief. Germany had made proposals ${ }^{3}$ to the United States to reduce to a minimum the dangers of naval warfare, but these had not been accepted. Germany was still ready to come to an agreement along these lines, and after professing a desire to confine warfare on sea and land to the armed forces of the belligerents, the note continued:

"In self-defense against the illegal conduct of British warfare, while fighting a bitter struggle for national existence, Germany had to resort to the hard but effective weapon of submarine warfare.

${ }^{3}$ That merchant ships should not be armed, that the United States should compel Great Britain to relax her restrictions upon Germany's trade, and that an embargo should be placed upon the exports of arms to the Allies. See above, p. $33 \mathrm{ff}$. 
"As matters stand, the German Government cannot but reiterate its regret that the sentiments of humanity which the Government of the United States extends with such fervor to the unhappy victims of submarine warfare, are not extended with the same warmth of feeling to many millions of women and children who, according to the avowed intention of the British Government, shall be starved, and who by sufferings shall force the victorious armies of the Central Powers into ignominious capitulation.

"The German Government, in agreement with the German people, fails to understand this discrimination, all the more as it has repeatedly and explicitly declared itself ready to use the submarine weapon in strict conformity with the rules of international law as recognized before the outbreak of the war, if Great Britain likewise was ready to adapt the conduct of warfare to these rules.

"Several attempts made by the Government of the United States to prevail upon the British Government to act accordingly failed because of flat refusal on the part of the British Government. Moreover, Great Britain again and again has violated international law, surpassing all bounds in outraging neutral rights. ...

"The German people knows that the Government of the United States has the power to confine the war to armed forces of the belligerent countries, in the interest of humanity and maintenance of international 


\section{AMERICA'S CASE AGAINST GERMANY}

law. The Government of the United States would have been certain of attaining this end had it been determined to insist, against Great Britain, on the incontrovertible rights to freedom of the seas. But, as matters stand, the German people is under the impression that the Government of the United States, while demanding that Germany, struggling for existence, shall restrain the use of an effective weapon and while making compliance with these demands a condition for maintenance of relations with Germany, confines itself to protests against illegal methods adopted by Germany's enemies. Moreover, the German people knows to what considerable extent its enemies are supplied with all kinds of war material from the United States.

"It will, therefore, be understood that the appeal made by the Government of the United States to sentiments of humanity and principles of international law can not, under the circumstances, meet the same hearty response from the German people which such an appeal otherwise always is certain to find here. If the German Government, nevertheless, is resolved to go to the utmost limit of concessions, it has been guided not alone by the friendship connecting the two great nations for over one hundred years, but also by the thought of the great doom which threatens the entire civilized world should the cruel and sanguinary war be extended and prolonged.

“The German Government, conscious of Germany's 
strength, twice within the last few months announced before the world its readiness to make peace on a basis safeguarding Germany's vital interests, thus indicating that it is not Germany's fault if peace is still withheld from the nations of Europe. The German Government feels all the more justified in declaring that responsibility could not be borne before the forum of mankind and history if after twenty-one months of the war's duration the submarine question, under discussion between the German Government and the Government of the United States, were to take a turn seriously threatening maintenance of peace between the two nations."

Germany declared that she wished to prevent such an occurrence, and that for the duration of the war she was prepared to confine its operations to the fighting forces of the belligerents,

"thereby also insuring the freedom of the seas, a principle upon which the German Government believes, now as before, that it is in agreement with the Government of the United States.

"The German Government, guided by this idea, notifies the Government of the United States that German naval forces have received the following order:

" "In accordance with the general principles of visit and search and the destruction of merchant vessels, recognized by international law, such vessels, both 


\section{AMERICA'S CASE AGAINST GERMANY}

within and without the area declared a naval war zone, shall not be sunk without warning and without saving human lives unless the ship attempt to escape or offer resistance.'

"But neutrals can not expect that Germany, forced to fight for existence, shall, for the sake of neutral interests, restrict the use of an effective weapon, if the enemy is permitted to continue to apply at will methods of warfare violating rules of international law. Such a demand would be incompatible with the character of neutrality, and the German Government is convinced that the Government of the United States does not think of making such a demand, knowing that the Government of the United States repeatedly declares that it is determined to restore the principle of freedom of the seas, from whatever quarter it has been violated."

The pledge thus made was immediately qualified by the ominous statement that Germany did "not doubt that the Government of the United States will now demand and insist that the British Government shall forthwith observe the rules of international law universally recognized before the war," and threatened that "should the steps taken by the Government of the United States not attain the object it desires to have the laws of humanity followed 
by all belligerent nations, the German Government would then be facing a new situation in which it must reserve to itself complete liberty of decision."

President Wilson replied by accepting the pledge and ignoring the qualification that America's case against Great Britain would have to be successfully pressed. He said:

"The Government of the United States feels it necessary to state that it takes it for granted that the Imperial German Government does not intend to imply that the maintenance of its newly announced policy is in any way contingent upon the course or result of diplomatic negotiations between the Government of the United States and any other belligerent Government, notwithstanding the fact that certain passages in the Imperial Government's note of the 4th instant might appear to be susceptible of that construction. In order, however, to avoid any possible misunderstanding, the Government of the United States notifies the Imperial Government that it can not for a moment entertain, much less discuss, a suggestion that respect by German naval authorities for the rights of citizens of the United States upon the high seas should in any way or in the slightest degree be made contingent upon the conduct of any other Government affecting the right of neutrals and non- 


\section{AMERICA'S CASE AGAINST GERMANY}

combatants. Responsibility in such matters is single, not joint; absolute, not relative."

The exchanges were concluded with Germany's note of May 8th, admitting the destruction of the Sussex through a mistake by the submarine commander in forming a too hurried judgment of the character of the vessel. $\mathrm{He}$ did not, therefore,

"act fully in accordance with the strict instruction which called upon him to exercise particular care.

"In view of these circumstances the German Government frankly admits that the assurance given to the American Government, in accordance with which passenger vessels were not to be attacked without warning, has not been adhered to in the present case. As was intimated by the undersigned in the note of the 4th instant, the German Government does not hesitate to draw from this resultant consequences. It therefore expresses to the American Government its sincere regret regarding the deplorable incident and declares its readiness to pay an adequate indemnity to the injured American citizens. It also disapproved of the conduct of the commander, who has been appropriately punished." 4

4 But no information has ever been available as to the nature of the penalty suffered by the commander in this case or in that of the Ancona. The commander of the submarine which sank the Lusitania was decorated. 


\section{CHAPTER X}

THE PARTING OF THE WAYS

From the date of these conditional pledges to the decree of January 31, 1917, there occurred no sinkings which were deemed by the United States to violate the promises made, although the warfare of submarines seemed very far from being conducted with a regard for noncombatant lives, whether enemy or neutral. Two vessels under charter by the American Commission for Relief in Belgium were among those sunk, and on May 8th the White Star liner Cymric, engaged in the freight service, was torpedoed without warning, five being killed and many wounded, but there were no Americans on board. During the latter part of May and the first weeks in June, submarine activities seemed to abate somewhat, but Germany issued a warning that a neutral vessel could be attacked, if, upon being commanded 


\section{AMERICA'S CASE AGAINST GERMANY}

to stop by. a submarine, it refused to obey. In the Mediterranean, the campaign was more successful than in the war zone, and in both regions during August and September submarines were able to account for about seventyfive vessels, some of them neutral. The safety and interests of American citizens were not affected, and so, from the purely national standpoint now taken by the United States, the German pledges had been kept. In October, however, there were sensational but not illegal developments.

A German submarine (U-53) of the largest type appeared on October 7 th in the harbor at Newport and lay there several hours. It was, the captain said, seventeen days out of Wilhelmshaven and had sufficient supplies of all kinds for a three months' cruise. The incident was a noteworthy one for the U-53 was the first war submarine to cross the Atlantic without a convoy, and that a war engine belonging to a European belligerent could rise silently from the sea in an American harbor showed more effectively than any theoretical argument could, that our days of "splendid isolation" are 
over. The U-53 left that evening and the next day sank five vessels at distances of from forty to eighty miles from the mainland. One Dutch, one Norwegian, and two British freighters thus met their fate, together with the Stephano, a British passenger liner running between New York and Halifax. The American steamer Kansan was stopped, but was allowed to proceed. No lives were lost as warning was given in each case and those on board the vessels took to small boats. That the "poor safety" thus accorded did not result in some casualties is due to the fact that seventeen American torpedo boat destroyers were sent out and helped to bring in the passengers and crew.

Now, although in those cases warning was given before the vessels were sunk, but for the services of the American torpedo boat destroyers some of the passengers of the Stephano would doubtless have been drowned or injured since the vessel was forty-two miles from land when sunk. Nevertheless the United States considered that its neutral rights had not been infringed and apparently made no protest. Furthermore, on August 31st the United States 


\section{AMERICA'S CASE AGAINST GERMANY}

had declined to accept the proposals of a memorandum from the French Government in which it was urged that the difficulty in determining the nationality of a submarine and its combatant character, and the likelihood that, if far from base it would be able to secure supplies surreptitiously, should exclude undersea boats from the benefits of the rules regarding the admission and sojourn of war and merchant vessels in neutral waters. Merchant submarines like the Deutschland and belligerent ones like the U-53 would, according to the policy of the United States, enjoy the same privileges as liners or cruisers belonging to one of the Entente Powers. A contrary rule was announced by some of the European neutrals.

But cases immediately arose which did affect the neutral rights of the United States. On October 30th the British steamships Marina and Rowanmore were sunk off the Irish coast. The former was a horse transport with Americans in the crew; the latter was a freighter with a mixed cargo. When the Marina was attacked six Americans lost their lives. On November 6th, the Peninsular \& Oriental liner 
Arabia was torpedoed in the Mediterranean without warning, but apparently all of the 450 passengers were saved. The next day the American Hawaiian steamship Columbian, with a cargo of steel for Italy, was torpedoed, the crew being compelled to take to open boats.

Since the destruction of the Marina caused the death of six Americans, and the attack on the Arabia was a violation of the pledge that "liners" would not be sunk without warning, the United States made representations in both cases to the Imperial German Government. The reply as to the Arabia stated that the submarine commander was convinced that it was a transport ship and consequently attacked without delay. If it could be shown that the Arabia was a passenger steamer, "the action of the commander would not have been in accordance with the instructions given him" and the case would then be "a regrettable mistake, from which the German Government would promptly draw the necessary consequences." As for the Marina all the pertinent facts were not at the disposal of Germany. But the issues presented 


\section{AMERICA'S CASE AGAINST GERMANY}

were very serious, ${ }^{1}$ and they were aggravated by the sinking off the Spanish coast of the American ship Chemung and in the Mediterranean of the British horse transport Russian, with the loss of seventeen Americans.

It was felt that a crisis was approaching even though on November 15th a denial was made by Dr. Alfred Zimmermann, German Secretary for Foreign Affairs, that neutral merchant ships were being sunk per se. The German naval forces were simply "sinking as a defensive measure ammunition transports and other contraband shipments to our enemies that are calculated to lengthen the war." This was being done "in punctilious compliance with the rules of international law applying to cruiser warfare." Accordingly, the statement continued, Germany would "continue to exercise her perfect good right to take these defensive measures. If neutrals have to lament the loss

${ }^{1}$ A statement issued by the British Admiralty announced that from May 5th (the date of Germany's Sussex pledge) to October 28th 22 British merchant ships had been torpedoed without warning and 131 non-combatants had lost their lives. Some of the details of these sinkings are particularly revolting. During the same period 107 British ships had been sunk, the crews and passengers being given time to take to open boats. 
of ships and cargoes, it should be remembered that the real blame lies on England."

In spite of the isolated cases of sinkings it was generally thought that Germany still stood by her pledges, and meanwhile occurred the peace proposals which obscured, in the popular mind at least, all thoughts of the submarine warfare. These proposals are slightly germane to the present discussion because they are mentioned in the final German communication. The first was made by Germany herself on December 12, 1916. Addressed to the neutral powers for transmission to the Allies, it expressed the willingness of the Central Powers to negotiate for peace and disclaimed any responsibility if the war continued. On December 18th President Wilson addressed a note to all the belligerents calling upon them to state the objects for which they were fighting in order to learn "how near the haven of peace may be for which all mankind longs with an intense and increasing longing." The German reply was couched in vague terms and merely expressed a willingness to send delegates to a meeting of the belligerent states. On the other hand, the re- 
plies of the Entente Allies to the German proposals (December 30th) and to President Wilson's note (January 10th, 1917) more nearly answered Mr. Wilson's request for a statement of the objects for which the war was being fought and the terms upon which peace would be agreed to. In addition to this, they constituted a severe arraignment of the part played by Germany in bringing on the war and her methods of conducting it. Germany's reply to the Allies, dated January 11th, did little more than repeat the first proposal. Finally, on January 22nd, Mr. Wilson appeared before the United States Senate, as the body associated with him "in the final determination of our international obligation," and set forth his views as to the nature of a European peace that would be likely to be permanent and the terms upon which the United States would join a League in order to insure such a peace by a joint guarantee.

Copies of this address were transmitted to the belligerent governments and in his communication of January 31st Count Bernstorff said that it had received careful consideration and 
had gratified the Imperial Government in "that the main tendencies of this important statement correspond largely to the desires and principles professed by Germany." The Imperial Government regretted "that the attitude of her enemies who are so entirely opposed to peace makes it impossible for the world at present to bring about the realization of these lofty ideals." This created a new situation and Germany was forced to new decisions-she must use every weapon at her disposal in the fight for existence.

"Since two years and a half England is using her naval power for a criminal attempt to force Germany into submission by starvation. In brutal contempt of international law the group of powers led by England not only curtail the legitimate trade of their opponents but they also by ruthless pressure compel neutral countries either to altogether forego every trade not agreeable to the Entente Powers or to limit it according to their arbitrary decrees. The American Government knows the steps which have been taken to cause England and her allies to return to the rules of international law and to respect the freedom of the seas. The English Government, however, insists upon continuing its war of starvation, 


\section{AMERICA'S CASE AGAINST GERMANY}

which does not at all affect the military power of its opponents but compels women and children, the sick and the aged, to suffer for their country pains and privations which endanger the vitality of the nation. Thus British tyranny mercilessly increases the sufferings of the world indifferent to the laws of humanity, indifferent to the protests of the neutrals whom they severely harm, indifferent even to the silent longing for peace among England's own allies. Each day of the terrible struggle causes new destruction, new sufferings. Each day shortening the war will on both sides preserve the life of thousands of brave soldiers and be a benefit to mankind.

"The Imperial Government could not justify before its own conscience, before the German people, and before history the neglect of any means destined to bring about the end of the war. Like the President of the United States, the Imperial Government had hoped to reach this goal by negotiations. Since the attempts to come to any understanding with the Entente Powers have been answered by the latter with the announcement of an intensified continuation of the war, the Imperial Government-in order to serve the welfare of mankind in a higher sense and not to wrong its own people-is now compelled to continue the fight for existence, again forced upon it, with the full employment of all the weapons which are at its disposal.

"Sincerely trusting that the people and Govern- 
ment of the United States will understand the motives for this decision and its necessity, the Imperial Government hopes that the United States may view the new situation from the lofty heights of impartiality and assist on their part to prevent further misery and avoidable sacrifice of human life."

The two memoranda enclosed announced a campaign on the high seas utterly unparalleled in its lawlessness. The first memorandum charged that the Entente Powers were violating all the rules of international law while Germany had not made unrestricted use of the weapon which she possessed in her submarines. Since the Entente Powers had made it impossible to come to an understanding based upon the equality of rights of all nations, "Germany is unable further to forego the full use of her submarines." The United States would understand, it was not doubted, that this situation was forced upon Germany by the brutal methods of warfare used against her and the determination of the Allies to crush the Central Powers. These considerations gave back to Germany the freedom of action which she reserved in her note on the Sussex, May 4, 1916. 
"Under these circumstances Germany will meet the illegal measures of her enemies by forcibly preventing after February 1, 1917, in a zone around Great Britain, France, Italy, and in the Eastern Mediterranean all navigation, that of neutrals included, from and to England and from and to France, etc. All ships met within that zone will be sunk.

"The Imperial Government is confident that this measure will result in a speedy termination of the war and in the restoration of peace which the Government of the United States has so much at heart. Like the Government of the United States, Germany and her allies had hoped to reach this goal by negotiations. Now that the war, through the fault of Germany's enemies, has to be continued, the Imperial Government feels sure that the Government of the United States will understand the necessity of adopting such measures as are destined to bring about a speedy end of the horrible and useless bloodshed. The Imperial Government hopes all the more for such an understanding of her position, as the neutrals have, under the pressure of the Entente Powers, suffered great losses, being forced by them either to give up their entire trade or to limit it according to conditions arbitrarily determined by Germany's enemies in violation of international law."

The second memorandum gave the details of the zone in which all kinds of merchant shipping 
would be sunk. Trade with the Entente Powers was absolutely barred. "Americans en route to the blockade zone on enemy freight steamers are not endangered," it was said, "as the enemy shipping firms can prevent such ships in time from entering the zone." American passenger steamers could continue undisturbed if the port of destination was Falmouth; if a specified course was taken; if the steamers were marked with the American flag on the hull as described; if the flags at the mast heads were arranged as indicated, and if the steamers were lighted at night. No other American vessels, however, could use these markings, the cargoes must be guaranteed to be of a non-contraband character, and only one steamer a week could sail in either direction, with arrival at Falmouth on Sunday and departure from Falmouth on Wednesday.

This declaration came as a thunderbolt. There had, it is true, been forecasts in the press reports from Germany that a resumption of an unrestricted submarine campaign was urged and might be attempted. Uncensored correspondence from Cologne (dated January 12th) 


\section{AMERICA'S CASE AGAINST GERMANY}

to the London Times, for example, said that more than one thousand underseas boats were in course of construction; three hundred were in use; less than one hundred had been destroyed, and a more extensive use of them was contemplated. But few indeed expected such a drastic announcement as that made on January 31st. What would be the attitude of the United States?

President Wilson announced his policy on February $3 d$ in an address to the two houses of Congress in joint session. He quoted the solemn warning of his Sussex note that unless Germany immediately abandoned her use of submarines contrary to international law and "the universally recognized dictates of humanity" the United States would sever diplomatic relations, and the German pledge, in reply, that it would "do its utmost to confine the operations of war for the rest of its duration to the fighting forces of the belligerents," instructions having been issued that vessels should not be sunk in the war zone "without warning and without saving human lives, unless these ships attempt to escape or offer resistance." This promise, 
however, as has been pointed out above, was qualified by the intimation that England must relax some of her restrictions on commerce; and since the rejoinder of the United States on May 8th to the effect that the rights of American citizens on the high seas could not be made contingent upon the conduct of any other belligerent was not replied to, the German pledge had been accepted unreservedly. This pledgeand likewise the many preceding it-was withdrawn by the decree of January 31 st, and his policy with regard to this action President Wilson went on to outline in measured words that deserve to be quoted in full:

"I think that you will agree with me that, in view of this declaration, which suddenly and without prior intimation of any kind deliberately withdraws the solemn assurance given in the Imperial Government's note of the fourth of May, 1916, this Government has no alternative consistent with the dignity and honor of the United States but to take the course which, in its note of the eighteenth of April, 1916, it announced that it would take in the event that the German Government did not declare and effect an abandonment of the methods of submarine warfare which it was then 


\section{AMERICA'S CASE AGAINS'T GERMANY}

employing and to which it now purposes again to resort.

"I have, therefore, directed the Secretary of State to announce to His Excellency the German Ambassador that all diplomatic relations between the United States and the German Empire are severed, and that the American Ambassador at Berlin will immediately be withdrawn; and, in accordance with this decision, to hand to His Excellency his passports.

"Notwithstanding this unexpected action of the German Government, this sudden and deeply deplorable renunciation of its assurances, given this Government at one of the most critical moments of tension in the relations of the two Governments, I refuse to believe that it is the intention of the German authorities to do in fact what they have warned us they will feel at liberty to do. I can not bring myself to believe that they will indeed pay no regard to the ancient friendship between their people and our own or to the solemn obligations which have been exchanged between them and destroy American ships and take the lives of American citizens in the willful prosecution of the ruthless naval program they have announced their intention to adopt. Only actual overt acts on their part can make me believe it even now.

"If this inveterate confidence on my part in the sobriety and prudent foresight of their purpose should unhappily prove unfounded; if American ships and 
American lives should in fact be sacrificed by their naval commanders in heedless contravention of the just and reasonable understandings of international law and the obvious dictates of humanity, I shall take the liberty of coming again before the Congress to ask that authority be given me to use any means that may be necessary for the protection of our seamen and our people in the prosecution of their peaceful and legitimate errands on the high seas. I can do nothing less. I take it for granted that all neutral Governments will take the same course.

"We do not desire any hostile conflict with the Imperial German Government. We are the sincere friends of the German people and earnestly desire to remain at peace with the Government which speaks for them. We shall not believe that they are hostile to us unless and until we are obliged to believe it; and we purpose nothing more than the reasonable defense of the undoubted rights of our people. We wish to serve no selfish ends. We seek to stand true alike in thought and in action to the immemorial principles of our people which I sought to express in my address to the Senate only two weeks ago-seek merely to vindicate our right to liberty and justice and an unmolested life. These are the bases of peace, not war. God grant we may not be challenged to defend them by acts of willful injustice on the part of the Government of Germany!"’ 
The same day Ambassador Bernstorff was given his passports, the American diplomatic and consular representatives were ordered to leave Germany, and the United States began to prepare for possible eventualities if Germany committed some "overt act." 


\section{CHAPTER XI}

OVERT ACTS, ARMED NEUTRALITY, AND WAR

Afrer the break in diplomatic relations every phase of Germany's activities showed that she was unwilling to yield and would insist upon carrying out the program which she had announced. The American representative in Berlin, Ambassador Gerard, did not receive the courtesies to which international law and comity entitled him; it was intimated that his departure and the safety of Americans who were leaving might be made dependent upon Mr. Gerard's agreeing to a revision of the old Prussian treaties so that the United States would be estopped from seizing the German ships in American harbors. Furthermore, it seemed like a studied affront to the United States when the Imperial Government persisted in detaining seventy-two American sailors from the Yarrowdale on the ground that they had 
208 AMERICA'S CASE AGAINST GERMANY

accepted pay on an armed vessel and were hence prisoners of war. The United States very properly insisted that they could not have this status unless they had committed hostile acts, and on February 16th the men were released. Humiliating indignities were reported to have been suffered by Americans leaving Berlin and altogether Germany seemed to be losing no opportunity to affront the United States.

The destruction of merchant vessels by submarines began on a wider and more successful scale than had at any time been the case since the first declaration of February, 1915. During the first two weeks after diplomatic relations were broken, nearly one hundred ships were reported sunk with a total of more than 200,000 tons. Of special concern to the United States were the sinking of two American vessels and an attack on the French steamer Athos which caused the death of an American missionary. More serious, however, was the virtual embargo which was laid on the mails and shipments of various sorts to Europe. With no protective measures decided upon by the Wilson Adminis- 


\section{OVERT ACTS-WAR}

tration, American vessels were naturally fearful of braving the submarine menace, and the country suffered a tremendous freight congestion as well as a serious diminution of its export trade.

At the end of three weeks it seemed to be clear that the threat of Mr. Wilson's address to Congress in breaking off diplomatic relations would have no effect, and so on February 26th he again addressed both houses, this time to ask for the authority he deemed necessary to safeguard the rights of the United States. He reported that two American vessels had been sunk : the Housatonic (February 3d), which appeared to be a case like that of the William $P$. Frye in which Germany had admitted liability and had safeguarded the lives of the crew with reasonable care, and the Lyman M. Law (February 12th) which "disclosed a ruthlessness of method which deserves grave condemnation, but was accompanied by no circumstances which might not have been expected at any time in connection with the use of the submarine against merchantmen, as the German Government has used it." Five Norwegian vessels 


\section{AMERICA'S CASE AGAINST GERMANY}

with Americans on board had been sunk, but the situation was practically the same as on February $3 \mathrm{~d}$ when diplomatic relations had been broken, with the exception of the fact that ships were tied up in American ports because of the unwillingness of the owners to incur risk without adequate protection and a congestion of commerce was growing more serious every day. No "overt act" had occurred, but the expressions of intention by the German authorities and press were not calculated to allay apprehension, and, "no thoughtful man can fail to see that the necessity for definite action may come at any time, if we are in fact, and not in word merely, to defend our elementary rights as a neutral nation. It would be most prudent to be unprepared." Mindful of the fact that the session of Congress was to expire almost immediately, President Wilson sought "to obtain from you full and immediate assurance of the authority which I may need at any moment to exercise," and declared:

"No one doubts what it is our duty to do. We must defend our commerce and the lives of our people in the midst of the present trying circumstances, 
with discretion but with clear and steadfast purpose. Only the method and the extent remain to be chosen, upon the occasion, if occasion should indeed arise. Since it has unhappily proved impossible to safeguard our neutral rights by diplomatic means against the unwarranted infringements they are suffering at the hands of Germany, there may be no recourse but to armed neutrality, which we shall know how to maintain and for which there is abundant American precedent.

"It is devoutly to be hoped that it will not be necessary to put armed forces anywhere into action. The American people do not desire it, and our desire is not different from theirs. I am sure that they will understand the spirit in which I am now acting, the purpose I hold nearest my heart and would wish to exhibit in everything $I$ do. $I$ am anxious that the people of the nations at war also should understand and not mistrust us. I hope that I need give no further proofs and assurances than I have already given throughout nearly three years of anxious patience that I am the friend of peace and mean to preserve it for America so long as I am able. I am not now proposing or contemplating war or any steps that need lead to it. I merely request that you will accord me by your own vote and definite bestowal the means and the authority to safeguard in practice the right of a great people who are at peace and who are desirous of exercising none but the rights of peace to follow 


\section{AMERICA'S CASE AGAINST GERMANY}

the pursuits of peace in quietness and good willrights recognized time out of mind by all the civilized nations of the world. No course of my choosing or of theirs will lead to war. War can come only by the willful acts and aggressions of others.

"... I request that you will authorize me to supply our merchant ships with defensive arms, should that become necessary, and with the means of using them, and to employ any other instrumentalities or methods that may be necessary and adequate to protect our ships and our people in their legitimate and peaceful pursuits on the seas. I request also that you will grant me at the same time, along with the powers I ask, a sufficient credit to enable me to provide adequate means of protection where they are lacking, including adequate insurance against the present war risks.

"I have spoken of our commerce and of the legitimate errands of our people on the seas, but you will not be misled as to my main thought-the thought that lies beneath these phrases and gives them dignity and weight. It is not of material interests merely that we are thinking. It is, rather, of fundamental human rights, chief of all the right of life itself. I am thinking, not only of the rights of Americans to go and come about their proper business by way of the sea, but also of something much deeper, much more fundamental than that. I am thinking of those rights of humanity without which there is no civili- 
zation. My theme is of those great principles of compassion and of protection which mankind has sought to throw about human lives, the lives of noncombatants, the lives of men who are peacefully at work keeping the industrial processes of the world quick and vital, the lives of women and children and of those who supply the labor which ministers to their sustenance. We are speaking of no selfish material rights but of rights which our hearts support and whose foundation is that righteous passion for justice upon which all law, all structures alike of family, of state, and of mankind must rest, as upon the ultimate base of our existence and our liberty. I cannot imagine any man with American principles at his heart hesitating to defend these things."

A measure was immediately prepared by the Foreign Relations Committee and introduced in the Senate to carry out President Wilson's policy of armed neutrality. It authorized the commanders and crews of all merchant vessels bearing the registry of the United States "to arm and defend such vessels against unlawful attacks." To the President was given power to supply such vessels with defensive arms, fore and aft, and "to employ such other instrumentalities and methods as may in his judgment and 
214 AMERICA'S CASE AGAINST GERMANY

discretion seem necessary and adequate to protect such vessels and the citizens of the United States in their lawful and peaceful pursuits on the high seas." A bond issue of $\$ 100,000,000$ was authorized to pay the necessary expenses. The House Committee on Foreign Affairs was unable to reach an immediate agreement. A similar measure was before it, but opposition developed to granting the President the very broad power of employing "such other instrumentalities and methods" as might be necessary, and it was urged also that the stipulation be made that the President should not protect ships carrying contraband of war.

On February 28th, with the apparent intention of rousing Congress to early action and informing the country of the dangers of the international situation and the consequences of the submarine warfare, the Administration made public a note from the German Foreign Minister to the German Minister in Mexico suggesting an offensive alliance with Japan against the United States. This remarkable communication was as follows: 


\section{"Berlin, Jan. 19, 1917.}

"On the 1st of February we intend to begin submarine warfare unrestricted. In spite of this, it is our intention to endeavor to keep neutral the United States of America.

"If this attempt is not successful, we propose an alliance on the following basis with Mexico: That we shall make war together and together make peace. We shall give general financial support, and it is understood that Mexico is to reconquer the lost territory in New Mexico, Texas, and Arizona. The details are left to you for settlement.

"You are instructed to inform the President of Mexico of the above in the greatest confidence as soon as it is certain that there will be an outbreak of war with the United States, and suggest that the President of Mexico, on his own initiative, should communicate with Japan suggesting adherence at once to this plan. At the same time, offer to mediate between Germany and Japan.

"Please call to the attention of the President of Mexico that the employment of ruthless submarine warfare now promises to compel England to make peace in a few months.

“Zimmermann."

The publication of this note diminished the opposition and the armed neutrality resolution passed the House of Representatives on March 
1st by an overwhelming vote, but the rules of the Senate which failed to limit debate permitted "a group of willful men," in Mr. Wilson's phrase, to prevent action before the time set for the Congress to come to an end. To call an immediate special session was futile on account of these rules, but at the extra session of the Senate held after the inauguration to pass upon nominations, the rules were radically revised, and an overwhelming majority of members in favor of a particular measure, as was the case with the armed neutrality resolution, will now be able to force a vote. On March 9th, President Wilson issued a proclamation calling Congress in special session for April 16th, the reason assigned being the necessity for a great variety of emergency legislation, but preparations for armed neutrality went on without legislative authorization and on March 12 th it was announced that the United States had "determined to place upon all American merchant vessels sailing through the barred areas an armed guard for the protection of the vessels and the lives of the persons on board." Meanwhile Germany continued to commit 
overt acts. Just before he started for the capitol to read his armed neutrality address to Congress, President Wilson received word of the sinking of the Laconia (February 25th) with the loss of twelve persons, among them two American citizens. On March 12th, the American steamship Algonquin was sunk and fourteen Americans who were members of the crew had to spend twenty-six hours in open boats. On March 19th, the sinking of three American ships was announced. The City of Memphis, plainly marked by the American flag and with her name in letters that could be read three miles away, was bound from Cardiff for New York in ballast; the Vigilancia bound for Havre with provisions, was torpedoed without warning and fifteen of her crew lost their lives. The third American ship whose sinking was announced was the Illinois, a tanker bound from Port Arthur, Texas, to London. ${ }^{1}$

${ }^{1}$ Other submarine depredations which affected American interests were as follows: The sinking of the Aztec, an armed merchant vessel, was reported on April 2d, the day of President Wilson's war message; the Healdton, an American oil ship, was sunk on March 22d, and of the twenty-one members of the crew who lost their lives, seven were Americans; two smaller American steamers were sunk in the Mediterranean on 


\section{AMERICA'S CASE AGAINST GERMANY}

These sinkings showed that armed neutrality was inadequate. On March 21st, the President summoned Congress into special session on April 2d "to receive a communication by the Executive on grave questions of national policy, which should be immediately taken under consideration," and steps were at once taken to mobilize the military and economic resources of the country for the prosecution of a war. Much had already been done.

It was practically a foregone conclusion that President Wilson intended to ask Congress to declare the existence of a state of war. The pretense of armed neutrality was anomalous and inadequate. As Mr. Wilson pointed out in

April 4th and 7 th; four Belgian relief ships, earrying 17,000 tons of food, were torpedoed. "On April 10 it was reported by the State Department that up to April 3, 1917, German submarines had sunk during the war 686 neutral vessels, including 19 American, and attacked unsuccessfully 79 others, including 8 American. Since the German war zone decree went into effect on Feb. 1 more than one-third of the vessels sunk were neutral, and a large number of other neutral vessels were terrorized into staying in port. The neutral vessels sunk were as follows:

"Norwegian, 410; Swedish, 111; Dutch, 61; Greek, 50; Spanish, 2; Argentine, 1; Brazilian, 1; American, 8. Total, 79."

The New York Times Current History, Vol. VI, p. 239 (May, 1917). 
his address, Germany would probably have the effrontery to treat American ships that were armed as pirates. Again, the use of force against one belligerent and not against the other in order to maintain neutral rights, was difficult of comprehension and was not given the support that would be accorded a declaration of war. Particularly was this the case with regard to munitions. Senator Stone represented a good deal more than his own opinion when he sought to amend the armed ship bill so that the United States could not arm or convoy vessels carrying absolute contraband to Great Britain or her allies. A large number of Americans believed that Germany was justified in taking any measures to stop shipments of munitions from reaching her enemies, and that the United States should not use force to protect her citizens engaged in this trade. They could not understand the justice of the indisputable principles of international law for which the United States had contended: That the trade in such articles should continue, subject to the belligerent rights of blockade, capture, visit and search, with the lives of the crew 


\section{AMERICA'S CASE AGAINST GERMANY}

being safe-guarded in every case. And if an armed munition ship had been destroyed by a German submarine, there would, I venture, have been no great outcry from American opinion and no overwhelming decision that the final overt act had occurred and war was the only possible resort. There has seemed to be a curious mental vacuity on the justice of the assertion that the crew of a munition ship have rights identical with those of a passenger liner, if both are unresisting, or if both resist the exercise of the belligerent authority. This was a very weak feature of our armed neutrality. On the other hand, wanton acts like the sinking of the Lusitania and Laconia appealed to the people as justifying war by the United States. If by reason of these overt acts war were embarked upon, then public opinion would sanction any measures which would contribute to the defeat of Germany; and the peculiar status which munition ships occupy in the popular mind would be done away with, for insuring their passage would be one of our contributions to the conduct of the war.

Armed neutrality, furthermore, could not 
protect Americans on board of belligerent merchant vessels. Should our sole answer to the German threats be the arming of our own vessels? Should we sit by quiescent when-as would certainly be the case unless the English measures against the submarines were extraordinarily successful-American citizens continued to lose their lives through the sinking of belligerent vessels? And, finally, so long as the United States maintained a pretense of neutrality, it would be more difficult to punish offenses against the Government. It is not possible constitutionality, while we are at peace, to put within federal jurisdiction all the activities of German agents in this country; we have even witnessed the ridiculously impotent expedient of attempting to punish plotters under the Sherman anti-trust law. More than that, rigorous definition and severe punishment for the acts which ought to be prohibited would be much more palatable to our liberty loving ideals if the country were actually at war and the punishment were for giving aid and comfort to the enemies of the United States-in short, for treason. The defense of the realm from the ac- 


\section{AMERICA'S CASE AGAINST GERMANY}

tivities of German agents within our territory would be easier from both standpoints if we abandoned an attempt to remain neutral.

All that I have said omitted a fundamental consideration: That the cause of the Allies is the cause of the United States; that our interests would be subserved by their speedy victory and that our interests would be menaced by their defeat; that it is our moral duty to give them what assistance we can in order to insure their success, irrespective of our grievances against Germany for her murder of American citizens. This was in part adverted to by Mr. Wilson when he addressed Congress. The submarine warfare was against all mankind, against all nations; and in entering the conflict we would be "but one of the champions of the rights of mankind," fighting "ffor democracy, for the right of those who submit to authority to have a voice in their own governments, for the rights and liberties of small nations, for a universal dominion of right by such a concert of free peoples as shall bring peace and safety to all nations and make the world itself at last free." 
Four days after the President's address, both Houses of Congress passed the joint resolution declaring that whereas the Imperial German Government had committed repeated acts of war against the United States, the state of war thus forced upon this country was formally declared, and the President was directed "to employ the entire naval and military forces of the United States and the resources of the Government to carry on war against the Imperial German Government; and to bring the conflict to a successful termination all the resources of the country are hereby pledged by the Congress of the United States.', This resolution was the formal declaration of the fifth war in which the United States had ever engaged with a foreign power. 


\section{CHAPTER XII}

\section{THE RIGHT OF RETALIATION}

$\mathrm{I}_{\mathrm{N}}$ view of the measured indictments which one after another Mr. Wilson's notes furnish of the German methods and of the ethically and legally justifiable ground for hostile measures on the part of the United States, it is unnecessary here to attempt any exhaustive summary. The list of American ships destroyed, the callous disregard of the nature of their nationality, passengers, and cargo, the destruction of vessels carrying women and children with the loss of many lives, and the final announcement of an unrestricted campaign of frightfulness have all been set forth. It only remains to comment on one phase of the controversy-namely, the lack of justification for reprisals like those of Germany, and the apparent lenience with which the United States has treated the British interferences with our trade. 
Both the British Orders in Council stopping trade to the Central Powers, and the German war zone decrees allege that they are proper retaliations for disregard of international law on the part of the enemy. The United States in its Lusitania note of July 21, 1915, answered this claim by asserting that "a belligerent act of retaliation is per se an act beyond the law, and the defense of an act as retaliatory is an admission that it is illegal." Now, reprisals are recognized belligerent rights and it is only to be expected that neutrals may to some extent be injured. But, there is a vast difference between a reprisal aimed directly at the enemy and calculated to have immediate effect on the conduct of the war, which incidentally affects neutrals, and one which is not directed against the armed forces of the enemy at all but wantonly and immediately kills or injures neutrals and noncombatants. As a recent writer of authority has said:

"Through reprisal and counter-reprisal, each exceeding the other in barbarity, war would inevitably revert to its most primitive form, and there would be nothing to prevent a final burning of prisoners at 


\section{AMERICA'S CASE AGAINST GERMANY}

the stake. Nor should overbidding be permitted in reprisals which tend to injure neutrals. An act of reprisal must not involve a more serious impairment of neutral rights than the alleged offense for which the reprisal is taken. For otherwise, through reprisal and counter-reprisal, all neutral rights might eventually disappear in such a world-war as is now raging.

"If our Government had taken this position, it would, I think, have enlisted the support of all neutrals, and its suggestions would probably have been accepted, at least after the establishment of peace, by all the countries now at war. And it would have found a clear and tenable ground on which to protest against the German 'war zone' proclamation. Applying the principles suggested, it could have said to Germany: Your proposal to sacrifice non-combatant lives and to endanger the lives of neutrals is not a legitimate retaliation for any measure, however illegal, which Great Britain has adopted; for the taking of life is no proper retaliation for the taking of goods." 1

In this important distinction we find the answer to the argument that we have treated England more leniently than Germany. Great Britain has had an almost absolute command of the

${ }^{1}$ Munro Smith, "American Diplomacy in the European War,' Political Science Quarterly, Vol. XXXI, pp. 481, 508. 
sea and she has very largely extinguished neutral trading rights. Against this action we made only feeble protests while Germany we answered with a threat of war. The difference is to be found in considerations of humanity, for England's restrictions upon trade have not caused the loss of a single life while the submarine campaign has resulted in the death of more than two thousand noncombatants. Rousseau first put emphasis upon war as a struggle between States and their armed forces and this gave rise to the distinction between combatants and noncombatants. The disregard of this distinction by Germany is the real cause of our answering her with acts and not words; had her reprisals been comparable in degree and humanity with those of England, we would simply have protested and would have laid a basis for claims in damages after the conclusion of the war.

But this takes no account of the German plea that the submarine campaign is a proper reply to the criminal and illegal attempt of England to starve Germany into submission through stopping all trade, or that the submarine is a 


\section{AMERICA'S CASE AGAINST GERMANY}

new weapon and that the old rules concerning the destruction of prizes are inapplicable. Thus Ambassador Bernstorff's note of January 31, 1917, protests that for two and a half years England had been "using her naval power for a criminal attempt to force Germany into submission by starvation," this being "in brutal contempt of international law." And in the note which he presented to the State Department on March 8, 1916, he said that "in order to fight her opponents' measures, which were absolutely contrary to international law, she chose for this purpose a new weapon, the use of which had not yet been regulated by international law, and, in doing so, could and did not violate any existing rules but only took into account the peculiarity of the new weapon, the submarine boat."

In answer to these claims attention should be directed to the able comment of Lord Robert Cecil, British Blockade Minister, made at the time of the exchanges with Germany over the Sussex. Lord Robert declared that

"So far as is known, the measures taken by Great Britain against German trade have cost no neutral 
life. Great Britain maintains that they are in accord with the principles of international law and is prepared to make good that claim. They can surely compare favorably, so far as consideration to neutrals is concerned, with a policy whose fruits are seen in the tragedies of the Lusitania, the Arabic, and the Sussex."

In answer to the plea that British trade restrictions compelled Germany to resort to the submarine campaign, he set out the following incidents :

"September, 1914.-Dutch vessel Maria, from California for Dublin and Belfast with cargo of grain for the civil population, sunk by the German cruiser Karlsruhe.

"Oct. 26, 1914.-The Admiral Ganteaume, with 2,000 unarmed refugees, sunk by a German submarine.

“December, 1914.-Admiral von Tirpitz foreshadowed adoption of submarine campaign.

“Jan. 27, 1915.-American ship William P. Frye, with wheat from Seattle for Queenstown, sunk by German auxiliary cruiser Kronprinz Wilhelm. [The William P. Frye was sunk by the Prinz Eitel Friedrich, according to the records.]

"Feb. 4, 1915.-Declaration by the German Government of their intention to institute a general sub- 


\section{AMERICA'S CASE AGAINST GERMANY}

marine blockade of Great Britain and Ireland, with the avowed purpose of cutting off all supplies from these islands. This blockade was put into effect officially Feb. 18, although, as a matter of fact, a merchant ship had been sunk by a German submarine at the end of January.

Not until March 11, 1915, did Great Britain attempt to cut off German trade absolutely and before that time submarine outrages had taken place. ${ }^{2}$ Noncombatants in Germany, furthermore, were not suffering so very severely, since the German Chancellor had recently declared:

"Our enemies forget that, thanks to the organizing powers of the whole nation, Germany is equal to the task of the distribution of victuals. Our stocks of bread and grain will not only be sufficient, but will leave an ample reserve with which to commence the new year. We have not run short of anything in the past, nor shall we run short of anything in the future."

Nevertheless, assuming that there was actual want in Germany it was a legitimate method of

" "As for their pretended tenderness for noncombatants," said Lord Robert, "their slaughter of old men, children, women, and girls in Belgium and Northern France, not to speak of the unreported proceedings of their honored allies in Armenia, forever prevents them from being heard in such a cause." 
warfare. In view of the use of Zeppelin bombs, poisoned gas, and submarine torpedoes, not to speak of atrocities, the German authorities, Lord Robert concluded, presumed "too far on the toleration of mankind when they complain of such a comparatively humane method of warfare as blockade."

The speciousness of the claim that the submarine, being a new engine of warfare, is an exception to established rules, and is subject to no restraints, has been pointed out in several of the American notes to Germany and needs only a bare mention here. As has been well said:

"In the use of a new weapon a belligerent nation may unquestionably violate well-recognized rules of international law. The armored tractor cars recently introduced by the British, for example, are new weapons, the use of which has not been regulated by international law; but it does not follow that Great Britain could lawfully use these new weapons to destroy enemy field hospitals.

"In using its submarines against merchant ships, Germany in fact invokes established rules of international law. It claims for submarines the rights accorded to cruisers. Cruisers have the right to capture enemy vessels and neutral vessels carrying contra- 


\section{AMERICA'S CASE AGAINST GERMANY}

band. Whenever it is impossible or even inexpedient to take a captured vessel into any of the captor's home ports for condemnation, it is permissible to sink it. Due provision, however, must always be made for the safety of the noncombatants, the crew and any passengers." 3

America's case against Germany, then, rests upon the ground, as Mr. Wilson said in his address to Congress, that American ships and American lives have been sacrificed by naval commanders "in needless contravention of the just and reasonable understandings of international law and the obvious dictates of humanity." All that the United States seeks is to vindicate its claims to "liberty and justice and an unmolested life," and this could only be accomplished by going to war with the Power which has sought to prevent the enthronement of public right as the guiding principle of the relations between states. The submarine campaign was simply the one manifestation of hostility to this ideal which was sufficient to bring in American Democracy on the side of England

"Smith, "American Diplomacy," Political Science Quarterly, Vol. XXXI, p. 495. 
and France and Russia. As I pointed out in the very beginning, it is fundamental; but for the insistence upon this weapon by Germany we would probably still be at peace, in spite of the terrible set-back to our moral and political ideals and the dangerous menace to our safety which the defeat of the Allies would have indubitably meant. Yet we should not forget the eloquent words of M. René Viviani, French Minister of Justice, and head of the French War Commission to the United States:

"Yes; doubtless you had your slaughtered dead to avenge, to avenge the insults heaped on your honor. You could not for one moment conceive that the land of Lincoln, the land of Washington, could bow humbly before the imperial eagle. But not for that did you rise; not for your national honor alone; do not say it was for that. You are fighting for the whole world; you are fighting for all liberty; you are fighting for civilization; that is why you have risen in battle." It is against " a whole race so madly intoxicated with conceit that it imagines it is predestined to dominate the world and is amazed to see free men rise and contest its rights. ... And when in faroff days after this war history shall tell why we fought... it will say why all the peoples rose in 


\section{AMERICA'S CASE AGAINST GERMANY}

battle, why the free allied peoples fought. Not for conquest! They were not nations of prey. No morbid ambitions lay festering in their hearts and consciences. Why then did they fight? To repel the most brutal and insidious of aggressions. They fought for the respect of international treaties trampled under foot by the brutal soldiery of Germany; they fought to raise all peoples of the earth to free breath, to the ideal of liberty for all, so that the world might be habitable for free men-or to perish."

That Mr. Wilson has been one of our most peace-loving presidents, history will not dispute. As the foregoing pages abundantly show, opportunity after opportunity was offered the Imperial Government of Germany to renounce lawlessness and to cease invasions of our sovereignty just as real as the landing of an army. The President's peace note of December called in vain for a definition of aims which would deny the intended subjugation of small states or a great German Empire under which liberty would perish. Armed neutrality, or a technical state of war with naval coöperation, money, and supplies would have sufficed if America had gone in only because her honor had been violated, her citizens murdered. Bui to send to 


\section{THE RIGHT OF RETALIATION}

France our finest men, in unlimited numbers secured on the basis of compulsory service; to pledge all the resources of the country, as did the congressional resolution declaring war - such a readiness for sacrifice means that America is not merely safeguarding her rights, but it means that America, in M. Viviani's phrase again, will "battle till the end for the deliverance of humanity, for the deliverance of democracy." Perhaps Woodrow Wilson waited wisely until the issue had been made translucently clear-until the liberalization of Russia removed the only anomaly and made the battle one of free nations against a would-be assassin of humanity, democracy, and the future peace of the world. 



\section{APPENDIX I}

PRESIDENT WILSON'S ADDRESS TO CONGRESS, APRIL 2, 1917, ASKING FOR A DECLARATION THAT A STATE OF WAR EXISTED

Gentlemen of the Congress: I have called the Congress into extraordinary session because there are serious, very serious, choices of policy to be made, and made immediately, which it was neither right nor constitutionally permissible that I should assume the responsibility of making.

On the third of February last I officially laid before you the extraordinary announcement of the Imperial German Government that on and after the first day of February it was its purpose to put aside all restraints of law or of humanity and use its submarines to sink every vessel that sought to approach either the ports of Great Britain and Ireland or the western coasts of Europe or any of the ports controlled by the enemies of Germany within the Mediter- 
ranean. That had seemed to be the object of the German submarine warfare earlier in the war, but since April of last year the Imperial Government had somewhat restrained the commanders of its undersea craft in conformity with its promise then given to us that passenger boats should not be sunk and that the warning would be given to all other vessels which its submarines might seek to destroy, when no resistance was offered or escape attempted, and care taken that their crews were given at least a fair chance to save their lives in their open boats. The precautions taken were meagre and haphazard enough, as was proved in distressing instance after instance in the progress of the cruel and unmanly business, but a certain degree of restraint was observed. The new policy has swept every restriction aside. Vessels of every kind, whatever their flag, their character, their cargo, their destination, their errand, have been ruthlessly sent to the bottom without warning and without thought of help or mercy for those on board, the vessels of friendly neutrals along with those of belligerents. Even hospital ships and ships carrying 
relief to the sorely bereaved and stricken people of Belgium, though the latter were provided with safe conduct through the prescribed areas by the German Government itself and were distinguished by unmistakable marks of identity, have been sunk with the same reckless lack of compassion or of principle.

I was for a little while unable to believe that such things would in fact be done by any government that had hitherto subscribed to the humane practices of civilized nations. International law had its origin in the attempt to set up some law which would be respected and observed upon the seas, where no nation had right of dominion, and where lay the free highways of the world. By painful stage after stage has that law been built up, with meager enough results, indeed, after all was accomplished that could be accomplished, but always with a clear view, at least, of what the heart and conscience of mankind demanded. This minimum of right the German Government has swept aside under the plea of retaliation and necessity and because it had no weapons which it could use at sea except these which it is impossible to em- 


\section{AMERICA'S CASE AGAINST GERMANY}

ploy as it is employing them without throwing to the winds all scruples of humanity or of respect for the understandings that were supposed to underlie the intercourse of the world. I am not now thinking of the loss of property involved, immense and serious as that is, but only of the wanton and wholesale destruction of the lives of noncombatants, men, women, and children, engaged in pursuits which have always, even in the darkest periods of modern history, been deemed innocent and legitimate. Property can be paid for; the lives of peaceful and innocent people cannot be. The present German submarine warfare against commerce is a warfare against mankind.

It is a war against all nations. American ships have been sunk, American lives taken, in ways which it has stirred us very deeply to learn of, but the ships and people of other neutral and friendly nations have been sunk and overwhelmed in the waters in the same way. There has been no discrimination. The challenge is to all mankind. Each nation must decide for itself how it will meet it. The choice we make for ourselves must be made with a 
moderation of counsel and a temperateness of juảgment befitting our character and our motives as a nation. We must put excited feeling away. Our motive will not be revenge or the victorious assertion of the physical might of the nation, but only the vindication of right, of human right, of which we are only a single champion.

When I addressed the Congress on the twenty-sixth of February last I thought that it would suffice to assert our neutral rights with arms, our right to use the seas against unlawful interference, our right to keep our people safe against unlawful violence. But armed neutrality, it now appears, is impracticable. Because submarines are in effect outlaws when used as the German submarines have been used against merchant shipping, it is impossible to defend ships against their attacks as the law of nations has assumed that merchantmen would defend themselves against privateers or cruisers, visible craft giving chase upon the open sea. It is common prudence in such circumstances, grim necessity indeed, to endeavor to destroy them before they have shown their own intention. 


\section{AMERICA'S CASE AGAINST GERMANY}

They must be dealt with upon sight, if dealt with at all. The German Government denies the right of neutrals to use arms at all within the areas of the sea which it has proscribed, even in the defense of rights which no modern publicist has ever before questioned their right to defend. The intimation is conveyed that the armed guards which we have placed on our merchant ships will be treated as beyond the pale of law and subject to be dealt with as pirates would be. Armed neutrality is ineffectual enough at best; in such circumstances and in the face of such pretensions it is worse than ineffectual: it is likely only to produce what it was meant to prevent; it is practically certain to draw us into the war without either the rights or the effectiveness of belligerents. There is one choice we cannot make, we are incapable of making: we will not choose the path of submission and suffer the most sacred rights of our nation and our people to be ignored or violated. The wrongs against which we now array ourselves are no common wrongs; they cut to the very roots of human life.

With a profound sense of the solemn and even 
tragical character of the step I am taking and of the grave responsibilities which it involves, but in unhesitating obedience to what I deem my constitutional duty, I advise that the Congress declare the recent course of the Imperial German Government to be in fact nothing less than war against the Government and people of the United States; that it formally accept the status of belligerent which has thus been thrust upon it; and that it take immediate steps not only to put the country in a more thorough state of defense but also to exert all its power and employ all its resources to bring the Government of the German Empire to terms and end the war.

What this will involve is clear. It will involve the utmost practicable coöperation in counsel and action with the governments now at war with Germany, and, as incident to that, the extension to those governments of the most liberal financial credits, in order that our resources may so far as possible be added to theirs. It will involve the organization and mobilization of all the material resources of the country to supply the materials of war and serve the inci- 


\section{AMERICA'S CASE AGAINST GERMANY}

dental needs of the nation in the most abundant and yet the most economical and efficient way possible. It will involve the immediate full equipment of the navy in all respects but particularly in supplying it with the best means of dealing with the enemy's submarines. It will involve the immediate addition to the armed forces of the United States already provided for by law in case of war at least five hundred thousand men, who should, in my opinion, be chosen upon the principle of universal liability to service, and also the authorization of subsequent additional increments of equal force so soon as they may be needed and can be handled in training. It will involve, also, of course, the granting of adequate credits to the Government, sustained, I hope, so far as they can equitably be sustained by the present generation, by well conceived taxation.

I say sustained so far as may be equitable by taxation because it seems to me that it would be most unwise to base the credits which will now be necessary entirely on money borrowed. It is our duty, I most respectfully urge, to protect our people so far as we may against the 
very serious hardships and evils which would be likely to arise out of the inflation which would be produced by vast loans.

In carrying out the measures by which these things are to be accomplished we should keep constantly in mind the wisdom of interfering as little as possible in our own preparation and in the equipment of our own military forces with the duty,-for it will be a very practical duty,-of supplying the nations already at war with Germany with the materials which they can obtain only from us or by our assistance. They are in the field and we should help them in every way to be effective there.

I shall take the liberty of suggesting, through the several executive departments of the Government, for the consideration of your committees, measures for the accomplishment of the several objects I have mentioned. I hope that it will be your pleasure to deal with them as having been framed after very careful thought by the branch of the Government upon which the responsibility of conducting the war and safeguarding the nation will most directly fall.

While we do these things, these deeply mo- 


\section{AMERICA'S CASE AGAINST GERMANY}

mentous things, let us be very clear, and make very clear to all the world what our motives and our objects are. My own thought has not been driven from its habitual and normal course by the unhappy events of the last two months, and I do not believe that the thought of the nation has been altered or clouded by them. I have exactly the same things in mind now that I had in mind when I addressed the Senate on the twenty-second of January last; the same that I had in mind when I addressed the Congress on the third of February and on the twentysixth of February. Our object now, as then, is to vindicate the principles of peace and justice in the life of the world as against selfish and autocratic power and to set up amongst the really free and self-governed peoples of the world such a concert of purpose and of action as will henceforth ensure the observance of those principles. Neutrality is no longer feasible or desirable where the peace of the world is involved and the freedom of its peoples, and the menace to that peace and freedom lies in the existence of autocratic governments backed by organized force which is controlled wholly by 


\section{APPENDIX}

their will, not by the will of their people. We have seen the last of neutrality in such circumstances. We are at the beginning of an age in which it will be insisted that the same standards of conduct and of responsibility for wrong done shall be observed among nations and their governments that are observed among the individual citizens of civilized states.

We have no quarrel with the German people. We have no feeling towards them but one of sympathy and friendship. It was not upon their impulse that their Government acted in entering this war. It was not with their previous knowledge or approval. It was a war determined upon as wars used to be determined upon in the old, unhappy days when peoples were nowhere consulted by their rulers and wars were provoked and waged in the interest of dynasties or of little groups of ambitious men who were accustomed to use their fellow men as pawns and tools. Self-governed nations do not fill their neighbor states with spies or set the course of intrigue to bring about some critical posture of affairs which will give them an opportunity to strike and make conquest. Such 


\section{AMERICA'S CASE AGAINST GERMANY}

designs can be successfully worked out only under cover and where no one has the right to ask questions. Cunningly contrived plans of deception or aggression, carried, it may be, from generation to generation, can be worked out and kept from the light only within the privacy of courts or behind the carefully guarded confidences of a narrow and privileged class. They are happily impossible where public opinion commands and insists upon full information concerning all the nation's affairs.

A steadfast concert for peace can never be maintained except by a partnership of democratic nations. No autocratic government could be trusted to keep faith within it or observe its covenants. It must be a league of honor, a partnership of opinion. Intrigue would eat its vitals away; the plottings of inner circles who could plan what they would and render account to no one would be a corruption seated at its very heart. Only free peoples can hold their purpose and their honor steady to a common end and prefer the interests of mankind to any narrow interest of their own.

Does not every American feel that assurance 
has been added to our hope for the future peace of the world by the wonderful and heartening things that have been happening within the last few weeks in Russia? Russia was known by those who knew it best to have been always in fact democratic at heart, in all the vital habits of her thought, in all the intimate relationships of her people that spoke their natural instinct, their habitual attitude towards life. The autocracy that crowned the summit of her political structure, long as it had stood and terrible as was the reality of its power, was not in fact Russian in origin, character, or purpose; and now it has been shaken off and the great, generous Russian people have been added in all their naïve majesty and might to the forces that are fighting for freedom in the world, for justice, and for peace. Here is a fit partner for a League of Honor.

One of the things that has served to convince us that the Prussian autocracy was not and could never be our friend is that from the very outset of the present war it has filled our unsuspecting communities and even our offices of government with spies and set criminal in- 


\section{AMERICA'S CASE AGAINST GERMANY}

trigues everywhere afoot against our national unity of counsel, our peace within and without, our industries and our commerce. Indeed it is now evident that its spies were here even before the war began; and it is unhappily not a matter of conjecture but a fact proved in our courts of justice that the intrigues which have more than once come perilously near to disturbing the peace and dislocating the industries of the country have been carried on at the instigation, with the support, and even under the personal direction of official agents of the Imperial Government accredited to the Government of the United States. Even in checking these things and trying to extirpate them we have sought to put the most generous interpretation possible upon them because we knew that their source lay, not in any hostile feeling or purpose of the German people towards us (who were, no doubt, as ignorant of them as we ourselves were), but only in the selfish designs of a Government that did what it pleased and told its people nothing. But they have played their part in serving to convince us at last that that Government entertains no real friendship for us and means to act 
against our peace and security at its convenience. That it means to stir up enemies against us at our very doors the intercepted note to the German Minister at Mexico City is eloquent evidence.

We are accepting this challenge of hostile purpose because we know that in such a government, following such methods, we can never have a friend; and that in the presence of its organized power, always lying in wait to accomplish we know not what purpose, there can be no assured security for the democratic governments of the world. We are now about to accept gauge of battle with this natural foe to liberty and shall, if necessary, spend the whole force of the nation to check and nullify its pretensions and its power. We are glad, now that we see the facts with no veil of false pretense about them, to fight thus for the ultimate peace of the world and for the liberation of its peoples, the German peoples included: for the rights of nations great and small and the privilege of men everywhere to choose their way of life and of obedience. The world must be made safe for democracy. Its peace must be planted 


\section{AMERICA'S CASE AGAINST GERMANY}

upon the tested foundations of political liberty. We have no selfish ends to serve. We desire no conquest, no dominion. We seek no indemnities for ourselves, no material compensation for the sacrifices we shall freely make. We are but one of the champions of the rights of mankind. We shall be satisfied when those rights have been made as secure as the faith and the freedom of nations can make them.

Just because we fight without rancor and without selfish object, seeking nothing for ourselves but what we shall wish to share with all free peoples, we shall, I feel confident, conduct our operations as belligerents without passion and ourselves observe with proud punctilio the principles of right and of fair play we profess to be fighting for.

I have said nothing of the governments allied with the Imperial Government of Germany because they have not made war upon us or challenged us to defend our right and our honor. The Austro-Hungarian Government has, indeed, avowed its unqualified endorsement and acceptance of the reckless and lawless submarine warfare adopted now without disguise by the 
Imperial German Government, and it has therefore not been possible for this Government to receive Count Tarnowski, the Ambassador recently accredited to this Government by the Imperial and Royal Government of Austria-Hungary; but that government has not actually engaged in warfare against citizens of the United States on the seas, and I take the liberty, for the present at least, of postponing a discussion of our relations with the authorities at Vienna. We enter this war only where we are clearly forced into it because there are no other means of defending our rights.

It will be all the easier for us to conduct ourselves as belligerents in a high spirit of right and faimess because we act without animus, not in enmity towards a people or with the desire to bring any injury or disadvantage upon them, but only in armed opposition to an irresponsible government which has thrown aside all considerations of humanity and of right and is running amuck. We are, let me say again, the sincere friends of the German people, and shall desire nothing so much as the early reëstablishment of intimate relations of mutual advantage 


\section{AMERICA'S CASE AGAINST GERMANY}

between us,-however hard it may be for them, for the time being, to believe that this is spoken from our hearts. We have borne with their present government through all these bitter months because of that friendship,-exercising a patience and forbearance which would otherwise have been impossible. We shall, happily, still have an opportunity to prove that friendship in our daily attitude and actions towards the millions of men and women of German birth and native sympathy who live amongst us and share our life, and we shall be proud to prove it towards all who are in fact loyal to their neighbors and to the Government in the hour of test. They are, most of them, as true and loyal Americans as if they had never known any other fealty or allegiance. They will be prompt to stand with us in rebuking and restraining the few who may be of a different mind and purpose. If there should be disloyalty, it will be dealt with with a firm hand of stern repression; but, if it lifts its head at all, it will lift it only here and there without countenance except from a lawless and malignant few.

It is a distressing and oppressive duty, Gen- 
tlemen of the Congress, which I have performed in thus addressing you. There are, it may be, many months of fiery trial and sacrifice ahead of us. It is a fearful thing to lead this great peaceful people into war, into the most terrible and disastrous of all wars, civilization itself seeming to be in the balance. But the right is more precious than peace, and we shall fight for the things which we have always carried nearest our hearts,-for democracy, for the right of those who submit to authority to have a voice in their own governments, for the rights and liberties of small nations, for a universal dominion of right by such a concert of free peoples as shall bring peace and safety to all nations and make the world itself at last free. To such a task we can dedicate our lives and our fortunes, everything that we are and everything that we have, with the pride of those who know that the day has come when America is privileged to spend her blood and her might for the principles that gave her birth and happiness and the peace which she has treasured. God helping her, she can do no other. 


\section{APPENDIX II}

The following memorandum ${ }^{1}$ has been prepared by the Department of State to show the submarine outrages which have directly affected American interests :

American ships damaged or destroyed by German submarines.

\begin{tabular}{|c|c|c|}
\hline Name of Vessel. & Date. & Particulars. \\
\hline 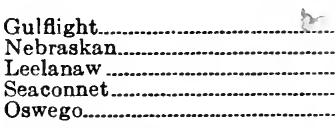 & $\begin{array}{l}\text { May } 2,1915 \\
\text { May 25, } 1915 \\
\text { July 25, } 1915 \\
\text { June 16, } 1916 \\
\text { Aug. 14, } 1916\end{array}$ & $\begin{array}{l}\text { Torpedoed. } \\
\text { Do. } \\
\text { Torpedoed and shelled. } \\
\text { Damaged by mine or torpedo. } \\
\text { Fired on } 10 \text { times by subma- }\end{array}$ \\
\hline $\begin{array}{l}\text { Lanao (Philippine) } \\
\text { Columbian. } \\
\text { Colena.en's.ainer. } \\
\text { St. Helen's } \\
\text { Rebecca Palmer } \\
\text { Sacramento } \\
\text { Housatonic } \\
\text { Lyman M. Law. } \\
\text { Vigilancia } \\
\text { City of Memphis } \\
\text { Illinois... } \\
\text { Aztec }\end{array}$ & $\begin{array}{l}\text { Oct. } 28,1916 \\
\text { Nov. } 7,1916 \\
\text { Nov. } 26,1916 \\
\text { Dec. } 10,1916 \\
\text { Dec. } 14,1916 \\
\text { Jan. } 9,1917 \\
\text { Feb. } 3,1917 \\
\text { Feb. } 13,1917 \\
\text { Mar. } 16,1917 \\
\text { Mar. 17, } 1917 \\
\text { Apr. } 1,1917\end{array}$ & $\begin{array}{l}\text { Sunk by submarine. } \\
\text { Do. } \\
\text { Fired on. } \\
\text { Attacked by submarine. } \\
\text { Fired on; slight damage. } \\
\text { Fired on. } \\
\text { Sunk. } \\
\text { Burned by submarine. } \\
\text { Torpedoed. } \\
\text { Sunk by gunfire. } \\
\text { Torpedoed. } \\
\text { Do. }\end{array}$ \\
\hline
\end{tabular}

SHIPS SUNK WITH LOSS OF AMERICAN LIVES

British ship Falaba, torpedoed March 28, 1915 (warned); 1 American lost.

British ship Lusitania, torpedoed May 7, 1915 (no warning); 114 Americans lost.

${ }^{1}$ Published in the Congressional Record, 65th Congress, 1st Session, p. 1006 (April 23, 1917). 
American ship Gulfight, torpedoed May 1, 1915 (no warning); 2 Americans lost.

British ship Armenian, torpedoed June 28, 1915 (ordered to stop; tried to escape); 23 Americans lost.

British ship Iberian, sunk July 31, 1915 (tricd to escape; stopped by shell fire); 3 Americans lost.

British ship Anglo-Californian, sunk July 4, 1915; 2 Amerieans lost.

British ship Hesperian, torpedoed September 4, 1915 (no warning); 1 American lost.

British ship Arabic, torpedoed August 19, 1915 (no warning); 3 Americans lost.

British ship Persia, believed to have been torpedoed; sunk December 30, 1915 (no warning); 2 Americans lost.

Italian ship Ancona, torpedoed November 9, 1915 (no warning); 7 Americans lost.

British ship Englishman, torpedoed March 27, 1916; 6 Americans lost ( 1 more whose nationality is doubtful).

British ship Sabota, sunk by gunfire October 20, 1916; 1 American lost.

British ship Marina, sunk by gunfire October 28, 1916 (warned); 8 Americans lost.

British ship Russian, torpedoed December 14, 1916 (no warning); 17 Americans lost.

British ship Eaveston, sunk by shell fire February 5, 1917; 1 American lost (1 other whose nationality is doubtful).

British ship Vedamore, torpedoed February 7, 1917 (no warning); 10 Americans lost.

British ship Turino, torpedoed February 7, 1917 (no warning) ; 1 American (?) lost.

French ship Athos, torpedoed February 22, 1917 (no warning); 1 American lost.

British ship Laconia, torpedoed February 26, 1917 (no warning); 8 Americans lost.

Norwegian ship Sjostad, believed torpedoed March 2, 1917 (no warning); 1 American lost. 


\section{AMERICA'S CASE AGAINST GERMANY,}

American ship Vigilancia, torpedoed March 16, 1917 (no warning); 5 Americans lost.

American ship Healdton, torpedoed March 21, 1917 (no warning); 7 Americans lost.

British ship Crispin, torpedoed March 29, 1917 (no warning); 68 Americans on board, 1 killed, 18 missing.

Total, 226 American lives lost.

On the Lusitania there were also 24 children born of foreign parents on American soil.

Carib (American), February 23, 1915 (mined); 1 American lost.

Koophandel (Belgian), August 1, 1915 (torpedoed); 1 American lost.

Batavier V (Dutch), May 16, 1916 (mined); 1 American lost. Alaunia (British), October 19, 1916 (possibly mined); 1 American lost (statement unreliable).

Cabotia (British), October 20, 1916 (torpedoed); 1 American lost.

Palermo (Italian), December 2, 1916 (torpedoed) ; 1 American lost.

Galgorm Castle (British), February 27, 1917 (torpedoed);

2 Americans lost.

Argo (Portuguese), March 23, 1917 (torpedoed); 3 Americans lost.

Aztec (American), April 1, 1917 (torpedoed); 28 missing. if Number of Am.ricans lost not established. 


\section{INDEX}

Admiral Ganteaume, the, sunk by submarine, 229 .

Algonquin, sinking of the, 217. Allies, cause of that of U. S., 3,222 ; reply of to peace proposals, 196.

American Civil War, starvation as method of warfare, 37 ; and doctrine of continuous voyage, 45 ; and use of neutral flags, 56 .

Ancona, sinking of the, $138 \mathrm{ff}$; punishment for submarine commander, $188 \mathrm{n}$.

Anglo-Californian, the, attacked by submarine, 88 , $94 \mathrm{n}$.

Arabia, sinking of the, 193.

Arabic, sinking of the, 97, 148, 176, 229; German excuse for, $100 \mathrm{ff}$.

Armed merchant vessels, $31 \mathrm{n}$, 65; German policy towards, 150, $153 \mathrm{ff}$; and Lusitania notes, 160; American proposals, $161 \mathrm{ff}$; congressional resolution, 163; President Wilson's letter on, 164; final position of U. S., 165.
Armed neutrality, $211 \mathrm{ff}$; inadequacy of, $218 \mathrm{ff}$. Armenian, the, sunk by submarine, 87, $94 \mathrm{n}$.

Asquith, H. H., 14. Athos, sinking of the, $208 \mathrm{n}$. Austria-Hungary, and Declaration of London, 42 ; munition shipments, 126; submarine campaign, 138; $A n$ cona incident, $141 \mathrm{ff}$; submarine pledges, 144.

Aztec, sinking of the, $217 \mathrm{n}$.

Baty, T., quoted, $13 \mathrm{n}$.

Belgium, invasion of, 3, 135. Bernstorff, Ambassador, 35, 75 n, 84 n, 108, 228; note on Arabic, 99; and dumdum bullets, 113; and munition shipments, $116 \mathrm{ff}$; submarine pledges, 147; handed passports, 206.

Berwindale, sinking of the, 171. Bethlehem Steel Company and submarine parts, 114.

Bismarck, Prince, 37.

Blockade, requirements for legal, 24; by submarines, $11 \mathrm{ff}$. 
Bryan, Secretary of State, proposals to belligerents for concessions, 31 ; on use of neutral flags, 55; resignation and Lusitania case, $81 \mathrm{n}$.

Caprivi, Count, 37.

Cecil, Lord Robert, 228, 230, 231.

Chemung, sinking of the, 194. City of Memphis, sinking of the, 217.

Columbian, sinking of the, 193. Combatants and noncombatants, distinction between, $4 \mathrm{ff}, 227$.

Congress, called in special session, 218.

Congressional resolution on armed merchantmen, 163.

Continuous voyage, doctrine of, $45 \mathrm{ff}$.

Contraband, absolute and conditional, 17 ff; England's attitude toward, 45.

"Conversations" over Lusitania, 149.

Crimean War and doctrine of continuous voyage, 45.

Cushing, the, attacked by German aeroplane, 60, 71, $75,76$.

Cymric, sinking of the, 189.

Declaration of London, disregard of by England, 17, 82; submarine campaign, 31 ; purpose of, 41 ; ratification by U. S., 42 ; in French and German naval codes, 42; continuous voyage, 45 ; destruction of prizes, 53, 63 .

Declaration of Paris, 156.

Declaration of War by Congress, 223.

Decree of January 31, 1917, unrestricted submarine warfare, 168, $196 \mathrm{ff}$.

Democracy, cause of Allies and U. S., $3 \mathrm{ff}, 222 \mathrm{ff}$.

Destruction of Prizes, $47 \mathrm{ff}$.

Deutschland, the, and American neutrality, 192.

Diplomatic relations with Germany, threatened break, 179; actual break, 206.

Eagle Point, sinking of the, 171. Englishman, sinking of the, 171.

Falaba, sinking of the, 60,72 , $76,94 \mathrm{n}$.

Famine, as method of warfare, $26 \mathrm{ff}, 40,127$.

Food supply of Germany, 230. Franco-Prussian War and munition shipments, 120.

French Arms Debate, 120.

Frye, William P., destruction of the, $28 \mathrm{n}, 60$; German liability under treaties, 61 , $89 \mathrm{n}, 104,106$; referred to, 148 n, 209, 229. 
Garner, James W., quoted, $49,51,96$ n, 128 n.

Geneva Conventions, 48.

Gerard, Ambassador, 86, 104 n, 170, 207.

German Embassy, advertised warning concerning war zone, 70 .

German Prize Code, 54, 61.

German theory of the state, 3 .

German War Book, 3.

Germany, alliance with Mexico and Japan against U. S., 5,215 ; violations of international law, $5 \mathrm{ff}$; war zone decree, $16 \mathrm{ff}$; decree controlling food stuffs, $27 \mathrm{n}, 45$; refusal of American proposals for concessions, 33, $74 \mathrm{n}$; and Declaration of London, 42; submarine pledges to U. S., $97 \mathrm{ff}, 147$; munitions of war, $116 \mathrm{ff}, 126$; armed merchantmen, 163; Sussex case, $171 \mathrm{ff}$; peace proposals, 196; diplomatic relations broken, 206; war declared, 223.

Great Britain, violations of international law by, 8, 90; American proposals for concessions, $74 \mathrm{n}$.

Gulfight, sinking of the, 60, $72,75,86,94 \mathrm{n}$.

Hague Conventions, and destruction of prizes, $50 \mathrm{ff}$; trade in munitions, $117 \mathrm{ff}$.
Healdton, sinking of the, $217 \mathrm{n}$.

Hesperian, torpedoing of the, $101 \mathrm{ff}$.

Higgins, A. Pearce, quoted, 157.

Hospital ships, immunity of, 9 n, 48.

Housatonic, sinking of the, 209.

Illinois, sinking of the, 217.

Imperator, the, sunk by submarine, $151 \mathrm{n}$.

Institute of International Law, 157.

International Law, violations of by Germany, 3, 4, 36; by Great Britain, 17, 43 ff, 90; changes during war, 134.

International Prize Court, 41.

Japan, alliance with Mexico and Germany against U. S., $5,215$.

Jefferson, Thomas, 118.

Kansas, the, stopped by the $U-53,191$.

Karlsruhe, the, 27 n, 229.

Kronprinz Wilhelm, the, 229.

Laconia, sinking of the, 217, 220.

La Follette, Senator, 35 n.

Lansing, Secretary of State, $54 \mathrm{n}$; last note on Lusitania, 89 ; on use of submarines against commerce, $93,94 \mathrm{n}$; 
on sinking of the Arabic, $99 \mathrm{ff}$, 108; letter to Senator Stone, 115; note to Austria on munitions, $129 \mathrm{ff}$; proposals as to armed merchantmen, 161; final position, 165.

Leelanaw, sinking of the, 89 . Leo, sinking of the, 88, $107 \mathrm{n}$. "Liners," meaning of, $105 \mathrm{ff}$. London Naval Conference, 42. Lusitania, the, use of American flag by, 54, 57; sinking of, $60 \mathrm{ff}$; note of U. S., $66 \mathrm{ff}$; German reply, $72 \mathrm{ff}$; second note of U. S., 75, 94 n; German rejoinder, $81 \mathrm{ff}$; "conversations" over, 96 ; and contraband, 97 ; German defense, 108; settlement, 149; punishment for commander, $188 \mathrm{n}$; referred to, $87,88,89$, 176, 177 n, 220, 225.

Lyman M. Law, sinking of the, 209.

Manchester Engineer, sinking of the, 171.

Maria, the, destruction of by a German cruiser, 27 n, 229. Marina, sinking of the, 192. Marshall, Chief Justice, 155.

Merchant vessels, immunity of from destruction without warning, $21 \mathrm{ff}, 47 \mathrm{ff}$; right to arm, $153 \mathrm{ff}$; conversion into warships, 153, 156.

Mexico, alliance with Japan and Germany against U. S.,
5, 215; American embargo on arms to, 112, 124.

Meyer-Gerhard, Dr. Anton, $85 \mathrm{n}$.

Monroe Doctrine, 5.

Morgan, J. H., quoted, $13 \mathrm{n}$.

Munitions, trade in, $109 \mathrm{ff}$; protests by Germany, 25, 35; and Prussian-American treaties, $62 \mathrm{ff}$; and American interests, 131; on Lusitania, 73. Munition ships, 219.

Napoleonic Wars and American neutrality, 118.

Nebraskan, the, damaged by torpedo, $85 \mathrm{ff}, 94 \mathrm{n}$.

Nereide, the, 155.

Neutral flag, use of by England, 30 ; by belligerent ships, 54 ff; protest by U. S., 55 ; British reply, 56.

Neutral vessels, destruction of, $52 \mathrm{ff}$.

Neutrals, trade with, 46.

Normandy, the, 88, 107.

Olympia, the, escape from torpedo, 13.

Orders in Council, 137, 225.

Orduna, the, escape from torpedo, 88, $94 \mathrm{n}, 107 \mathrm{n}$.

Overt acts, $210 \mathrm{ff}$.

"Paper blockades," 24.

Patria, sinking of the, 170.

Peace proposals by President Wilson, $195 \mathrm{ff}$. 
Persia, sinking of the, 146, 148. Petrolite, the, shelled by submarine, $146 \mathrm{n}$.

Pinzon, the, 122.

Prinz Eitel Frederick, the, 61, 229.

Prussian-American Treaties, 61, 89 n, 104, 137 n, 207.

Realpolitik, 82.

Reprisals, 225.

Retaliation, right of, $17 \mathrm{ff}$, $91 \mathrm{n}, 224 \mathrm{ff}$.

Rousseau, J. J., 227.

Rowanmore, sinking of the, 192. Russo-Japanese War, war zones in, $11 \mathrm{ff}$; destruction of neutral prizes, $52 \mathrm{ff}$; sale of munitions during, 115 .

Russian, sinking of the, 194. Russian Revolution, 235.

Schneider, Commander, 102.

Schurz, Carl, 120.

Seward, Secretary, 119.

Sherman anti-trust law and German plots, 221.

Silius, sinking of the, 170.

Smith, Munro, quoted, 226, 231.

Spanish American War and munition shipments, 121.

Starvation as method of warfare, 197, 227.

Stephano, sinking of the, 191. Stone, Senator, 115, 163, 219. "Strict accountability" note of U. S., 20 ff, 56 n, 108.
Submarine mines, and Hague Conventions, 12; laid by England, 15; by Germany, 15.

Submarine warfare, and international ruthlessness, 2; admission by Germany of illegality, 33; unfitness for use against commerce, 68 ; and dictates of humanity, 69; as valid means of retaliation, 90,226 ; in the Mediterranean, 138 ff; Austrian pledges, 144; German pledges, 147; as new weapon, $228 \mathrm{ff}$.

Sussex, sinking of the, 8, 92, 106, 148, 171; Germany's defense, 172; President Wilson's note, 173; threatened break, 179, 202; Germany's reply, 181; qualified pledge, 186; pledge withdrawn, 199.

Thrasher, Leon C., 60.

Tubantia, sinking of the, 170 .

$U-53$, the, sinkings by off Newport, 190.

United States, protest against war zone decree, $20 \mathrm{ff}, 80$; proposals for mutual concessions, $31 \mathrm{ff}$; and Declaration of London, $41 \mathrm{ff}$; and neutral flags, $54 \mathrm{ff}$; diplomatic victory, 103; attitude on armed merchantmen, $153 \mathrm{ff}$; final position on 
armed merchantmen, $165 \mathrm{ff}$; and armed neutrality, $211 \mathrm{ff}$; declaration of war by, 223 .

Vigilancia, sinking of the, 217. Ville de la Ciotat, sinking of the, 147.

Viviani, René, quoted, 233.

Von Tirpitz, Admiral, 16, 229.

War as struggle between states, 227.

War zones, legality of, $11 \mathrm{ff}$; declaration of by Great Britain, 13; by Germany, $16 \mathrm{ff}, 47$; protest of U. S., 20; German policy in, 65 .

White, Andrew D., 122.

Wilhelmina, the, seizure of by British cruiser, $27 \mathrm{n}$.

Wilson, Woodrow, on justification of war, 2 ; war address to Congress, 6, $237 \mathrm{ff}$; note on
Sussex, 9; on Lusitania, $66 \mathrm{ff}$; on trade in munitions, $116 \mathrm{ff}$; on sinking of Ancona, 139 ; letter to Senator Stone on armed merchantmen, 163; peace proposals, $195 \mathrm{ff}$; severs diplomatic relations, 206; and armed neutrality, $211 \mathrm{ff}$; asks for declaration of war, 222; peace loving president, 234.

Yarrowdale, American prisoners from the, 207.

Yasaka Maru, sinking of the, 147.

Zimmermann, Dr. Alfred, proposals of Japanese-Mexican alliance against U. S., 5, 215 ; statement on submarine warfare, 194. 


\section{DUE DATE}

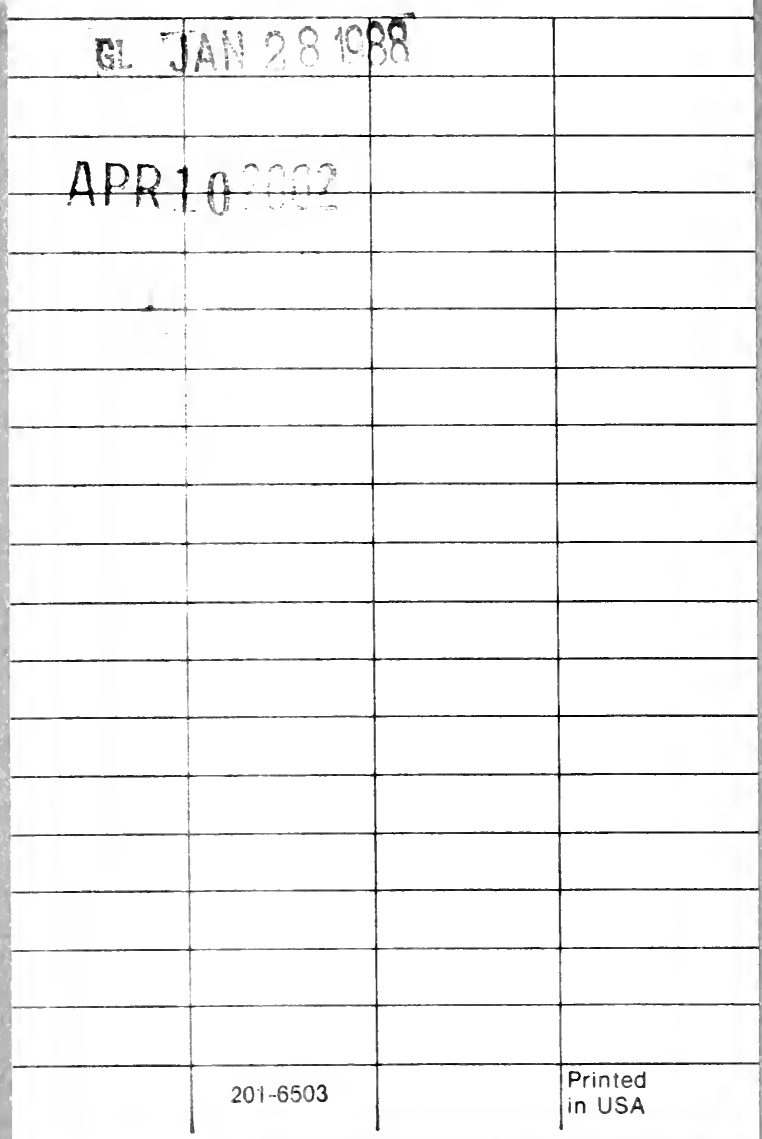




$$
940.91 R 632
$$


